\title{
Sponges of Western Mediterranean seamounts: new genera, new species, and new records
}

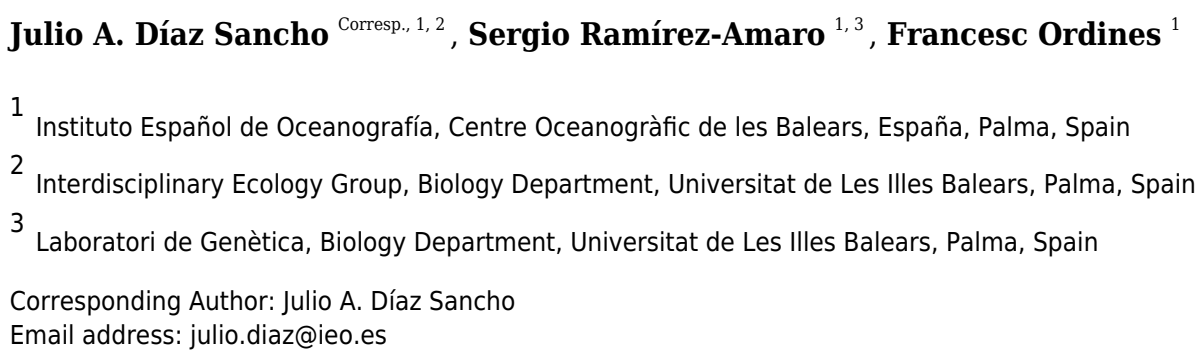

Background. The seamounts Ses Olives (SO), Ausias March (AM) and Emile Baudot (EB) at the Mallorca Channel (Balearic Islands, western Mediterranean), are poorly explored areas containing rich and singular sponge communities. Previous works have shown a large heterogeneity of habitats, including rhodolith beds, rocky, gravel and sandy bottoms and steeped slopes. This diversity of habitats provides a great opportunity for improving the knowledge of the sponges from Mediterranean seamounts. Methods. Sponges were collected during several surveys carried out by the Balearic Center of the Spanish Institute of Oceanography at the Mallorca Channel Seamounts. Samples were obtained using a beam-trawl, rock dredge and remote operated vehicle. Additional samples were obtained from fishing grounds of the Balearic Islands continental shelf, using the sampling device GOC-73. Sponges were identified through the analysis of morphological and molecular characters. Results. A total of 60 specimens were analyzed, from which we identified a total of 19 species. Three species and one genus are new to science: Foraminospongia balearica gen. nov. sp. nov., Foraminospongia minuta gen. nov. sp. nov. and Paratimea massutii sp. nov. Heteroxya cf. beauforti represents the first record of the genus Heteroxya in the Mediterranean Sea. Additionally, this is the second report of Axinella spatula and Haliclona (Soestella) fimbriata since their description. Moreover, the species Petrosia (Petrosia) raphida, Calyx cf. tufa and Lanuginella pupa are reported for the first time in the Mediterranean Sea. Petrosia (Strongylophora) vansoesti is reported here for the first time in the western Mediterranean Sea. Haliclona (S.) fimbriata is reported here for the first time in the north-western Mediterranean Sea. Hemiasterella elongata is reported here for the second time in the Mediterranean Sea. The species Melonanchora emphysema, Rhabdobaris implicata, Polymastia polytylota, Dragmatella aberrans, Phakellia ventilabrum and Pseudotrachya hystrix are reported for first time off Balearic Islands. Following the Sponge Barcoding project goals, we have sequenced the 
Cytochrome Oxidase subunit I (COI) and the 28S ribosomal fragment (C1-D2 domains) for Foraminospongia balearica sp. nov., Foraminospongia minuta sp. nov., $\mathrm{H}$. cf. beauforti and $C$. cf. tufa, and the COI for Paratimea massuti sp. nov. We also provide a phylogenetic analysis to discern the systematic location of Foraminospongia gen. nov., which, in accordance to skeletal complement, is placed in the Hymerhabdiidae family. A brief biogeographical discussion is provided for all these species, with emphasis on the sponge singularity of SO, AM and the EB seamounts and the implications for their future protection. 


\section{Sponges of Western Mediterranean seamounts: new 2 genera, new species, and new records}

3 Julio A. Díaz ${ }^{1,2}$, Sergio Ramírez-Amaro ${ }^{1,3}$ \& Francesc Ordines ${ }^{1}$,

$4{ }^{1}$ Instituto Español de Oceanografía, Centre Oceanogràfic de les Balears, Moll de Ponent s/n,

507015 Palma (Spain).

6 Interdisciplinary Ecology Group, Biology Department, University of the Balearic Islands,

7 Carretera de Valldemossa km 7.5, 07122 Palma (Spain).

8 '3aboratori de Genètica, Biology Department, University of the Balearic Islands, Carretera de

9 Valldemossa km 7.5, 07122 Palma (Spain).

10 Corresponding author:

11 Julio A. Díaz ${ }^{1}$

12 Moll de Ponent s/n, Palma, Spain/Illes Balears, 07015

13 E-mail: julio.diaz@ieo.es 


\section{Abstract}

Background. The seamounts Ses Olives (SO), Ausias March (AM) and Emile Baudot (EB) at the Mallorca Channel (Balearic Islands, western Mediterranean), are poorly explored areas containing rich and singular sponge communities. Previous works have shown a large heterogeneity of habitats, including rhodolith beds, rocky, gravel and sandy bottoms and steeped slopes. This diversity of habitats provides a great opportunity for improving the knowledge of the sponges from Mediterranean seamounts.

Methods. Sponges were collected during several surveys carried out by the Balearic Center of the Spanish Institute of Oceanography at the Mallorca Channel Seamounts. Samples were obtained using a beam-trawl, rock dredge and remote operated vehicle. Additional samples were obtained from fishing grounds of the Balearic Islands continental shelf, using the sampling device GOC-73. Sponges were identified through the analysis of morphological and molecular characters.

Results. A total of 60 specimens were analyzed, from which we identified a total of 19 species. Three species and one genus are new to science: Foraminospongia balearica gen. nov. sp. nov., Foraminospongia minuta gen. nov. sp. nov. and Paratimea massutii sp. nov. Heteroxya cf. beauforti represents the first record of the genus Heteroxya in the Mediterranean Sea. Additionally, this is the second report of Axinella spatula and Haliclona (Soestella) fimbriata since their description. Moreover, the species Petrosia (Petrosia) raphida, Calyx cf. tufa and Lanuginella pupa are reported for the first time in the Mediterranean Sea. Petrosia (Strongylophora) vansoesti is reported here for the first time in the western Mediterranean Sea. Haliclona $(S$.) fimbriata is reported here for the first time in the north-western Mediterranean Sea. Hemiasterella elongata is reported here for the second time in the Mediterranean Sea. The species Melonanchora emphysema, Rhabdobaris implicata, Polymastia polytylota, Dragmatella aberrans, Phakellia ventilabrum and Pseudotrachya hystrix are reported for first time off Balearic Islands. Following the Sponge Barcoding project goals, we have sequenced the Cytochrome Oxidase subunit I (COI) and the 28S ribosomal fragment (C1-D2 domains) for Foraminospongia balearica sp. nov., Foraminospongia minuta sp. nov., $H$. cf. beauforti and $C$. cf. tufa, and the COI for Paratimea massuti sp. nov. We also provide a phylogenetic analysis to discern the systematic location of Foraminospongia gen. nov., which, in accordance to skeletal complement, is placed in the Hymerhabdiidae family. A brief biogeographical discussion is provided for all these species, with emphasis on the sponge singularity of SO, AM and the EB seamounts and the implications for their future protection.

Keywords: Biodiversity, Sponges, New genus, New species, New records, DNA barcoding, Seamounts, Mediterranean Sea. 


\section{Introduction}

68 Seamounts are structures of high ecological and biological interest (Rogers, 2018), which provide excellent habitat for a rich communities of filter-feeding animals, such as corals, crinoids and sponges (Samadi et al., 2007). These organisms are favored by enhanced currents, scarcity of fine sediment, accidented topography and predominance of hard substrata, features that characterize Seamounts (White \& Mohn, 2004). Sponges are ubiquitous on seamounts, where they tend to form dense and diverse aggregations that provide habitat and refuge to other animals like crustaceans, mollusks and fishes (Samadi et al., 2007). Also, they are involved in benthicpelagic coupling and recycling of nutrients, both processes of utmost importance in oligotrophic areas like the Mediterranean Sea, where they may contribute to the maintenance of higher trophic levels (de Goeij et al., 2013).

Despite their importance, very little is known about sponges of the Mediterranean seamounts, which is in contrast to the vast number of studies on sponge taxonomy available in other domains like the continental shelf or the submarine canyons (e.g. Vacelet, 1961, 1969; Pulitzer-Finali, 1978, 1983; Boury-Esnault, Pansini \& Uriz, 1994; Pansini, Manconi \& Pronzato, 2011; Bertolino et al., 2015; Longo et al., 2018; Manconi et al., 2019; Enrichetti et al., 2020). However, in recent years the increase in the use of Remote Operated Vehicles (ROV) has facilitated the access and study of Seamounts. Currently, information on sponges is available from the Erathostenes seamount in the Levantine Sea (Galil \& Zibrowius, 1998), the Vercelli seamount in the northern Tyrrhenian Sea (Bo et al., 2011), the Ulisse and Penelope seamounts in the Ligurian Sea (Bo et al., 2020), the Avempace, Alboran Ridge, Seco de los Olivos and

Maldonado, 2014; De la Torriente et al., 2018; Corbera et al., 2019), and the Stone Sponge, Ses Olives, Ausias March and Emile Baudot seamounts in the Balearic Sea (OCEANA, 2011; Aguilar et al., 2011; Maldonado et al., 2015). However, most of these works adress the sponges at a community level, focusing on a general habitat characterization. Nonetheless, the studies adressing taxonomy have revealed that the Mediterranean seamounts are habitats for rare, poorly-known, or new species. For example, Aguilar et al., (2011) reported the carnivorous sponge Lycopodina hypogea (Vacelet \& Boury-Esnault, 1996) at the Ausias March seamount, representing the first sighting of this species outside littoral caves. A singular reef formed by the Lithistid Leiodermatium pfeifferae (Carter, 1873) was recorded at the Stone Sponge seamount, being the first report of this species in the Mediterranean Sea (Maldonado et al., 2015).

Determining which species are present on a given seamount, and hence the seamount's biodiversity is a first step towards the development of management plans to protect these habitats. It is also crucial to understand seamounts' biocenosis, their structure and dynamics, how they can be affected by human disturbances, and to monitor potential biological invasions and long-term community changes (Clark et al., 2012; Danovaro et al., 2020).

Sponges are problematic as they are difficult to identify, which may lead to incorrect or underestimated biodiversity values. The use of molecular markers, a powerful tool to help in sponge identification, has shown that this group is much more specious than previously thought, 
107

108

109

110

111

112

113

114

115

116

117

118

119

120

121

122

123

124

125

126

127

128

129

130

131

132

133

134

135

136

137

138

139

140

141

142

143

144

145

146

and cryptic species are very common (Cárdenas et al., 2012). Thus, detailed morphological descriptions supported by a complete genetic database are crucial for future studies.

The objective of this work was to improve the taxonomic knowledge on the sponges at three seamounts of the Mallorca Channel in the Balearic Islands: Ses Olives, Ausias March and Emile Baudot. Currently, these seamounts are being assessed for inclusion in the Natura 2000 network, under the scope of the LIFE IP INTEMARES project. One of the goals of this project is to improve the scientific knowledge of areas of ecological interest that harbor rich, vulnerable and protected habitats and species, which is necessary knowledge for the development of management plans. High abundance and diversity of invertebrates were observed during several surveys carried out in 2018, 2019, and 2020 at these seamounts, highlighting sponges as the dominant group. In the present paper we provide detailed descriptions of 18 demosponges and one hexactinellida, including a new genus and four new species, together with new descriptions and records of poorly-known taxa. For the new and dubious species, the sequences of two most used barcoding genes, the mitochondrial Cytochrome Oxidase subunit I (COI) and the nuclear $28 \mathrm{~S}$ ribosomal fragment (C1-D2 domains), are also provided.

\section{Materials and Methods}

\section{Study area}

The Mallorca Channel is located in the Balearic Promontory (western Mediterranean Sea), between the islands of Mallorca and Ibiza. The area harbors three seamounts: Ses Olives (SO; $1^{\circ}$ 58' 58.8' N, 38 57' 36" E) and Ausias March (AM; $\left.1^{\circ} 49^{\prime} 4.8^{\prime \prime} \mathrm{N}, 38^{\circ} 44^{\prime} 49.2^{\prime \prime} \mathrm{E}\right)$ located east of Ibiza and Formentera islands, and Emile Baudot (EB; $\left.2^{\circ} 30^{\prime} 0^{\prime \prime} \mathrm{N}, 38^{\circ} 43^{\prime} 55.2^{\prime \prime} \mathrm{E}\right)$ located south of Mallorca and east of Ibiza-Formentera (Fig. 1). The seamounts SO, AM and EB are 375, 264 and $600 \mathrm{~m}$ high, respectively and 10 to $17 \mathrm{~km}$ long, with tabular summits elongated in NE-SW trends and located at 225-290, 86-115 and 94-150 m depth, respectively. SO and AM are of orogenic origin, emerging from depths around 900 and $600 \mathrm{~m}$ in their eastern sides and being separated from Ibiza and Formentera islands by depths around 600 and $400 \mathrm{~m}$. By contrast, EB is a guyot of volcanic origin, which in its western side emerges from a plain around $900 \mathrm{~m}$ deep, with numerous fields of pockmark type depressions, located between SO and AM. At the eastern side of EB there is the so-called Emile Baudot scarpment, which descend down to $2600 \mathrm{~m}$ deep and connects the EB to the abyssal plain of the Algerian sub-basin (between the Balearic Isands and the Algerian coast) (Acosta et al., 2004).

The Algerian sub-basin hydrodynamics are mainly affected by density gradients, receiving warm and less saline Atlantic waters (Pinot et al., 2002). These surface waters have high seasonal temperature variation, ranging from $13^{\circ} \mathrm{C}$ during winter to $26^{\circ} \mathrm{C}$ during summer, when a strong vertical temperature gradient is established between 50 and $100 \mathrm{~m}$ deep. The water column below this depth shows fewer variations than in other parts of the western Mediterranean Sea, being mainly influenced by the Levantine Intermediate Water (LIW). This water mass, originated in the eastern Mediterranean, has temperature and salinity around $13.3^{\circ} \mathrm{C}$ and 38.5 ppt, respectively, and is situated approximately between 200 and $700 \mathrm{~m}$ deep, just above the 
147 Western Mediterranean Deep Water, which is located in the lowest part of the water column

148

149

150

151

152

153

154

155

156

157

158

159

160

161

162

163

164

165

166

167

168

169

170

171

172

173

174

175

176

177

178

179

180

181

182

183

184

185

186 (Monserrat et al., 2008). The western Mediterranean Intermediate Water, characterized by lower temperature $\left(\sim 12.5^{\circ} \mathrm{C}\right)$ because it is formed during winter in the Gulf of Lions by deep convection when sea-air heat flux losses are high enough, is found at 100-300 m deep, but does not reach the Mallorca Channel every year (Monserrat et al., 2008).

Within the general oligotrophy of the Mediterranean, the southern Balearic Islands waters in the Algerian sub-basin show more pronounced oligotrophy than waters of the Balearic sub-basin located north of the Archipelago, and above all than the adjacent waters off the Iberian Peninsula and the Gulf of Lions (Estrada, 1996; Bosc et al., 2004). The lack of supply of nutrients from land runoff and the lower influence of shelf/slope fronts flowing along the Iberian Peninsula and the northern insular shelf edge could explain these differences (Massuti et al., 2014; and references cited therein).

\section{Sampling}

Sponge samples were collected at SO, AM and EB seamounts with a Jennings type beam trawl (BT) of 2 and $0.5 \mathrm{~m}$ horizontal and vertical openings, respectively, and a $5 \mathrm{~mm}$ mesh size codend, a rock dredge (RD) and the Remote Operated Vehicle (ROV) Liropus 2000 with an extensible arm. Sampling was performed during INTEMARES research surveys carried out in 2018, 2019 and 2020 on board of the R/Vs Angeles Alvariño and Sarmiento de Gamboa (Fig. 1). Additional samples from trawl fishing grounds of the continental shelf off Mallorca and Menorca were collected during the MEDITS research surveys carried out in 2017, 2019 and 2020 using the bottom trawl net GOC-73 of 2.5-3 $\mathrm{m}$ and 18-22 $\mathrm{m}$ vertical and horizontal openings, respectively and a $10 \mathrm{~mm}$ mesh size cod-end, on board the R/V Miquel Oliver (Fig. 1). The sampling strategy of the MEDITS surveys is detailed in Bertrand et al. (2002) and Spedicato et al. (2019). BT and GOC-73 have been shown efective for sampling macro-benthic species of the epibenthic and nektobenthic communities of sedimentary bottoms, respectively (Reiss et al., 2006; Fiorentini et al., 1999; Ordines \& Massutí, 2009). The SCANMAR and MARPORT systems were used to control the deployment and retrieval of both gears to the bottom. By contrast, RD and ROV were used for sampling rocky bottoms and steep slopes. A summary of sampling stations used in the present work can be found in Table 1.

On board, specimens were photographed and stored in absolute EtOH. External morphology, color and texture were annotated, prior to conservation. Spicule preparations and histological sections were made according to the standard methods described by Hooper (2003). All the specimens were deposited in the Marine Fauna Collection (http://www.ma.ieo.es/cfm/) based at the Centro Oceanográfico de Málaga (Instituto Español de Oceanografía), with the numbers from CFM7356 to CFM7417 (Table S1).

The electronic version of this article in Portable Document Format (PDF) will represent a published work according to the International Commission on Zoological Nomenclature (ICZN), and hence the new names contained in the electronic version are effectively published under that Code from the electronic edition alone. This published work and the nomenclatural acts it contains have been registered in ZooBank, the online registration system for the ICZN. The 
187

188

189

190

191

192

193

194

195

196

ZooBank LSIDs (Life Science Identifiers) can be resolved and the associated information viewed through any standard web browser by appending the LSID to the prefix http://zoobank.org/. The LSID for this publication is: [urn:lsid:zoobank.org:pub:47EC2384-A88C-4654-8425-

A7A46BC47AC5]. The online version of this work is archived and available from the following digital repositories: PeerJ, PubMed Central and CLOCKSS.

\section{Morphological descriptions}

Spicules were observed with a Nikon S-Ke optical microscope and photographed with a CMOS digital camera. Images were processed using the Fiji software (Schindelin et al., 2012). Whenever possible, at least 30 spicules per spicule type were measured. Spicules measures are written as length: min-average-max x thickness: min-average- max $\mu \mathrm{m}$. Tangential and transversal thick sections were made with a scalpel and, if necessary, dehydrated with alcohol, mounted in DPX and observed under a compound microscope. Aliquots of suspended spicules were transferred onto foil, air dried, sputter coated with gold and observed under a HITACHI S$3400 \mathrm{~N}$ scanning electron microscope (SEM).

\section{Molecular analysis}

DNA was extracted from a piece of choanosomal tissue $\left(\sim 2 \mathrm{~cm}^{3}\right)$ using the DNeasy Blood and Tissue Extraction kit (QIAGEN). Polymerase chain reaction (PCR) was used to amplify the Cytochrome C Oxidase subunit I (COI; DNA barcoding) and the C1-D2 domains of the 28S ribosomal gen, with the universal primers LCO1490/HCO2198 (Folmer et al., 1994) and C1' ASTR/D2 (Vân Le et al., 1993; Chombard et al., 1998), respectively. PCR was performed in 50 $\mu \mathrm{l}$ volume reaction $\left(34.4 \mu \mathrm{lddH} 20,5 \mu \mathrm{l}\right.$ Mangobuffer, $2 \mu \mathrm{DNTPs}, 3.5 \mathrm{MgCl}_{2}, 1 \mu \mathrm{l}$ of each primer, $1 \mu \mathrm{l} \mathrm{BSA}, 0.1 \mu \mathrm{l} \mathrm{TAQ}$ and $2 \mu \mathrm{LNA}$ ). The PCR thermal profile used for COI amplification was $\left[94^{\circ} \mathrm{C} / 5 \mathrm{~min} ; 37\right.$ cycles $\left(94^{\circ} \mathrm{C} / 15 \mathrm{~s}, 46^{\circ} \mathrm{C} / 15 \mathrm{~s}, 72^{\circ} \mathrm{C} / 15 \mathrm{~s}\right) ; 72^{\circ} \mathrm{C} / 7$ min].28S amplification was carried out as detailed in Chombard et al., (1998). PCR products were visualized with 1\% agarose gel, purified using the QIAquickR PCR Purification Kit (QIAGEN) and sequenced at Macrogen Inc. (South Korea).

Sequences were imported into BioEdit 7.0.5.2. (Hall, 1999) and checked for quality and accuracy with nucleotide base assignment. Sequences were aligned using Mafft (Katoh et al., 2002). The resulting sequences were deposited in the GenBank database (http://www.ncbi.nlm.nih.gov/genbank/) under the following accession numbers: MW858346MW858351 for COI sequences and MW881149-MW881153 for 28S sequences; Table S1).

To assess the phylogeny of Foraminospongia balearica sp nov. and Foraminospongia minuta sp. nov., two different approaches were used: Bayesian Inference (BI) and Maximum likelihood (ML). Here, we selected closely related sequences belonging to the orders Agelasida, Axinellida, Scopalinida and Biemnida, obtained after a BLAST search (Altschul et al., 1990). Additionally, two sequences belonging to the order Suberitida were used as outgroup. A complete list of the used sequences is available at Table S1. BI and ML analyses were performed with the CIPRES science gateway platform (http://www.phylo.org; Miller et al., 2010) using Mr Bayes version 3.6.2 (Ronquist et al., 2012) and RAxML (Stamatakis, 2014). For Mr Bayes, we conducted four independent Markov chain Monte Carlo runs of four chains each, with 5 million generations, 
227

228

229

230

231

232

233

234

235

236

237

238

239

240

241

242

243

244

245

246

247

248

249

250

251

252

253

254

255

256

257

258

259

sampling every $1000^{\text {th }}$ tree and discarding the first $25 \%$ as burn-in, while RAXML was performed under the GTRCAT model with 1000 bootstrap iterations. Convergence was assessed by effective sample size (ESS) calculation and was visualised using TRACER version 1.5. Genetic distance (p-distance) and number of base differences between pair of DNA sequences were estimated with MEGA version 10.0.5 software (Kumar et al., 2018).

\section{Results}

A total of 60 specimens belonging to 2 classes, 9 orders, 13 families, 15 genera and 19 species were analyzed. All these species were collected at the Mallorca Channel seamounts, while three of them (Phakellia robusta Bowerbank, 1866, Petrosia (Petrosia) raphida Boury-Esnault, Pansini \& Uriz, 1994 and Hemiasterella elongata (Topsent, 1928) were also found at the continental shelf around Mallorca and Menorca. In situ images of some of these sponges, obtained with ROV from the seamounts of the Mallorca Channel, are shown in Figure 2.

\section{Systematics}

Phylum PORIFERA Grant, 1836

Class DEMOSPONGIAE Sollas, 1885

Suborder HETEROSCLEROMORPHA Cárdenas, Pérez \& Boury-Esnault, 2012

Order AGELASIDA Hartman, 1980

Family HYMERHABDIIDAE Morrow, Picton, Erpenbeck, Boury-Esnault, Maggs \& Allcock, 2012

\section{Genus Foraminospongia gen. nov.}

(Figs. 2B, 2F, 2H; Fig. 3; Fig. 4, Fig. 5, Fig. 6; Table 2)

\section{Type species}

\section{Foraminospongia balearica sp. nov.}

\section{Diagnosis}

Hymerhabdiidae with massive, massive-tubular or bushy growth form, with styles, subtylostyles, tylostyles, and rhabdostyles. Besides, curved or angulated oxeas may be present. Ectosome with an aspicular dermal membrane supported by a plumoreticulated skeleton of styles, subtylostyles and tylostyles. Pores grouped into inhalant areas. Choanosome confusedly plumoreticulated.

\section{Etymology}

From the Latin foramen (pores) and spongia (sponge). The name refers to the fact that in both species, theira skin has areas where pores are grouped, giving a characteristic macroscopical appearance. 
Foraminospongia balearica sp. nov.

(Figs. 2B, 2F, 2H; Fig. 3; Fig. 4; Fig. 5; Table 2)

\section{Diagnosis}

Massive-tubular to bushy Foraminospongia, with styles, rhabdostyles and oxeas.

\section{Etymology}

The name refers to the Balearic Islands, the area where the species has been collected.

\section{Material examined}

Holotype: CFM-IEOMA-7356/i802, St 37, AM, ROV.

Paratypes: CFM-IEOMA-7357/i144, St 4, EB, BT; CFM-IEOMA-7358/i293_1, St 9, AM, BT; CFM-IEOMA-7359/i239 (not described), St 8, AM, BT; CFM-IEOMA-7360/i745 (not described), St 26, EB, BT; CFM-IEOMA-7361/i824_4, St 39, EB, ROV.

Specimens observed but not sampled: St 12, EB, BT; St 14, EB, BT.

\section{Comparative material}

Foraminospongia minuta sp. nov.: CFM-IEOMA-7362/i439, St 27, RD, SO; CFM-IEOMA7363/i474, St 29, SO, RD.

Rhabderemia sp.: CFM-IEOMA-7415/1729_1 (only a slide deposited at the CFM-IEOMA), St 35, EB, RD.

\section{Description}

Massive-tubular or bushy sponges (Figs. 2B, 2F, 2H and Fig. 3A). Largest specimens up to $6 \mathrm{~cm}$ in diameter. When present, tubes are $2-3 \mathrm{~cm}$ in height and $1 \mathrm{~cm}$ in diameter. Sometimes several tubes are fused on another of its sides. Consistency slightly elastic, brittle, easily broken when manipulated. Surface smooth, rough to the touch. Color in life golden yellow, tan after preservation in EtOH. A translucid membrane is present, more evident near the oscula (Fig. 3B). Subdermal grooves forming a visible pattern (Fig. 3C). Circular oscula 0.3-0.6 cm. In most cases, oscula are placed at the end of tubes, however, the holotype also has a large osculum in the main body (Fig. 3B).

\section{Skeleton}

Ectosome characterized by a plumoreticulated tangential skeleton and a dermal membrane (Figs. 4A, 4B and 4C). In some areas of the dermal membrane there are small pores gathered. These porae areas correspond to the grooves that are perceptible to the eye. Choanosome, confusedly plumoreticulated with extensive spaces and ascending spicule tracts of 2-5 styles, sometimes protruding the surface. The tracts contain abundant spongin. In between the tracts transversal spicules are abundant (Figs. 4D-4E).

\section{Spicules}


294 Styles (Fig. 3A-3D): Fusiform, most gently curved, but sometimes abruptly curved once or

295

296

297

298

299

300

301

302

303

304

305

306

307

308

309

310

311

312

313

314

315

316

317

318

319

320

321

322

323

324

325

326

327

twice. When the curvature is in the last portion of the spicule, they may resemble rhabdostyles.

Roundish heads and sharp tips, sometimes telescoped, strongylote forms present. Swellings may happen at the head or below, sometimes barely visible, sometimes more patent, rarely tuberculated (Fig. 3D). Size range constant between specimensspecimens, not influenced by depth nor area (Table 2). They measure 177-375-634 x 3-9-9-14 $\mu \mathrm{m}$.

Rhabdostyles (Fig. 3E): Uncommon. Abruptly curved below the head. Stylote, subtylote and tylote modifications present. Round head and acerated tips. They measure 90-143-179 x 3-5-7 $\mu \mathrm{m}$. specimens

Oxeas (Fig. 3F): specimensCurved or bent, with one, two or several curvatures, sometimes slightly sinuous. Tips acerated or telescoped. They measure 249-520-763 x 3-ㅁ-13 $\mu \mathrm{m}$. Their abundance varies between specimens.

\section{Genetics}

Two COI Folmer fragment sequences were obtained for the Holotype (CFM-IEOMA-7356/i802) and for one paratype (CFM-IEOMA-7358/i293_1) (Genbank id's MW858346 and MW858347, respectively). Besides, we obtained a $28 S$ sequence (C1-D2 domains) for the Holotype (Genbank id MW881153).

\section{Ecological notes}

The species is very abundant on the EB and AM, between 100 and $169 \mathrm{~m}$ (Table 2). It can be mainly found on rhodolith beds and sedimentary bottoms with gravel, together with other sponges like Poecillastra compressa (Bowerbank, 1866), Axinella spp., Halichondria spp. or some Haplosclerids, as well as with a very broad number of crustaceans and echinoderms. It was also collected down to $433 \mathrm{~m}$ (St 14).

\section{Foraminospongia minuta sp. nov.}

(Fig. 6; Table 2)

\section{Diagnosis}

Small, massive-encrusting and greyish in color Foraminospongia, with only styles and rhabdostyles as spicules.

\section{Etymology}

The name refers to the small size of the two collected specimens.

\section{Material examined}

Holotype: CFM-IEOMA-7362/i439, St 27, SO, RD.

Paratype: CFM-IEOMA-7363/i474, St 29, SO, RD.

\section{Comparative material}

PeerJ reviewing PDF | (2021:04:59975:2:0:NEW 2 Jul 2021) 
Foraminospongia balearica sp. nov.: CFM-IEOMA-7357/i144, St 4, EB, BT; CFM-IEOMA7358/i293_1, St 9, AM, BT; CFM-IEOMA-7356/i802, St 37, AM, ROV; CFM-IEOMA7361/i824_4, St 39, EB, ROV.

Rhabderemia sp.: CFM-IEOMA-7415/ i729_1, St 35, EB, RD.

\section{Description}

Small massive-encrusting sponge (Figs.6A and 6B), about $1.5 \mathrm{~cm}$ in diameter and $0.5 \mathrm{~cm}$ in height. Consistency: compressible and slightly crumby. Velvety surface. The holotype was brownish due to mud, the paratype was greyish, both in life and after preservation in EtOH. Translucent membrane that can be peeled off is present, with grooves forming a distinguishable pattern (Fig. 6B). A single, circular oscule is present on the holotype.

\section{Skeleton}

The ectosome consists of a tangential reticulation of styles (Fig. 6C), and some loose rhabdostyles.

The choanosome is a plumoreticulated net of styles, with some loose rhabdostyles (Fig. 6D).

\section{Spicules}

Styles (Figs. 6E and 6F): Fusiform, gently curved or straight. Heads roundish and swelled in most cases. Sharp tips. Most are tylota. Size range variable between the holotype and the paratype (Table 2). They measure 244-465-658 x 9-14-21 $\mu \mathrm{m}$.

Rhabdostyles (Fig. 6G and 6H): Uncommon. Abruptly curved below the head, most with roundish, tylota modifications at the head and sharp tips. They measure 147-209-262 x 7-ㅁ-9 $\mu \mathrm{m}$.

\section{Genetics}

Sequences of COI Folmer fragment and 28S C1-D2 domains were obtained for the holotype and deposited in Genbank under accession numbers MW858348 and MW881151, respectively.

\section{Ecological notes}

Both specimens were found at SO, between 288 and $318 \mathrm{~m}$ deep, associated to hard bottoms with fossil ostreids reefs.

\section{Remarks on $F$. balearica sp. nov. and $F$. minuta sp. nov.}

Regarding the interspecific variability of $F$. balearica sp. nov., the spicules of the studied specimens are in the same size range, except for the styles of the specimen from AM (CFMIEOMA-7358/i293_1), which are shorter and thinner than those of the specimens from EB. Also, specimen CFM-IEOMA-7358/i293_1 has much more abundant oxeas than the others.

Regarding F. minuta sp. nov., the features of this species support the differential diagnostic characters of the genus Foraminospongia (plumoreticulated choanosomal skeleton, ectosome formed by a reticulation of spicules, dermal aspicular membrane with poral areas, presence of 
362

363

364

365

366

367

368

369

370

371

372

373

374

375

376

377

378

379

380

381

382

383

384

385

386

387

388

389

390

391

392

393

394

395

396

397

398

399

400

401

large styles and small rhabdostyles), but differs from $F$. balearica sp. nov. in its external morphology, being much smaller and massive-encrusting compared to massive-tubular or bushy and of a greyish color instead of golden yellow in the latter. Also, the spicular complement is different: F. minuta sp. nov. lacks oxeas and has longer and thicker styles and rhabdostyles. The differences in the size of the styles between the holotype and the paratype are notable, considering that both were collected at similar depths and habitats. These differences could suggest intraspecific variability for the spicule size within the species; however, more specimens are needed to corroborate this statement.

The morphological differences between the two species are backed by genetic results. The phylogenetic reconstructions for COI and $28 S$ fragments show well-supported separation between the two $F$. balearica sp. nov. sequences and the $F$. minuta sp. nov. sequence. Between the two species, the differences in bp and p-distance (in percentage) for COI Folmer and the $28 S$ fragments were $1 \mathrm{bp} / 0.2 \%$ and $1 \mathrm{bp} / 0.1 \%$, respectively.

\section{Remarks on the genus Foraminospongia}

The family Hymerhabdiidae was recently erected to include the genera Hymerhabdia, Prosuberites and some species of the polyphyletic genus Axinella and Stylissa (Morrow et al., 2019). Here, we propose Foraminospongia as a new hymerhabdiid genus. The main differences between Foraminospongia gen. nov. and both Hymerhabdia and Prosuberites are the growing habit, with Foraminospongia gen. nov. being massive, massive-tubular or bushy against encrusting. Also, it differs from Prosuberites in the presence of rhabdostyles and oxeas. However, the presence of rhabdostyles and oxeas is shared with Hymerhabdia, but the genetic differentiation between Foraminospongia and H. typica (type species of Hymerhabdia) is clear (Fig. 7). In addition, the ectosome with a dermal membrane and grouped pore areas of Foraminospongia is not present in any Hymerhabdia apart Hymerhabdia oxeata (Dendy, 1924) that has a dermal membrane, although neither Dendy nor the re-examination done by Hooper $\&$ Van Soest (1993) described pore areas. Therefore, $H$. oxeata could represent an intermediateintermediate stage between genuine Hymerhabdia and Foraminospongia species. However, the last statement is only speculative and must be checked in future works.

As stated before, there are species of Axinella and Stylissa that are grouped inside Hymerhabdiidae. Although currently all these species are kept in Axinellida and Suberitida, respectively (Van Soest et al., 2021), they are phylogenetically related to Foraminospongia (see Fig. 7). To resolve this relatedness, we have included in the phylogenetic analysis sequences of A. damicornis (Esper, 1794), A. verrucosa (Esper, 1794), A. corrugata (George \& Wilson, 1919), S. carteri (Dendy, 1889) and S. massa (Carter, 1887) used by Morrow et al. (2012) to define Hymerhabdiidae. The resulting trees show that those species are clearly different from Foraminospongia, which is corroborated by their morphology (Pansini, 1984; Hooper \& Van Soest, 2002).

The genus Rhabderemia (Order Biemnida, family Rhabderemiidae) resembles Foraminospongia in having rhabdostyles and possessing a plumoreticulated choanosomal skeleton. However, most Rhabderemia also have peculiar rugose microscleres (thraustoxeas, spirosigmata, 
402

403

404

405

406

407

408

409

410

411

412

413

414

415

416

417

418

419

420

421

422

423

424

425

426

427

428

429

430

431

432

433

434

435

436

437

438

439

thraustosigmata, microstyles). To clarify the potential relatedness of Rhabderemia and Foraminospongia, we have included in the phylogenetic analyses the species Rhabderemia sorokinae Hooper, 1990, R. indica Dendy, 1905 and R. destituta Van Soest \& Hooper, 1993. Moreover, we included in the COI tree one sequence of an encrusting Rhabderemia sp. (CFMIEOMA-7415/ i729_1; Genbank ID MW881152) collected at the EB, with spined rhabdostyles, toxas and spirosigmata (Fig. 7B). Other sequences of Biemnida available at the genbank have also been included (see Table S1).

The sequence of Rhabderemia sp. (CFM-IEOMA-7415/ i729_1; Genbank ID MW881152) clustered together with $R$. sorokinae, a Great Barrier Reef sponge which also has spined rhabdostyles, toxas and spirosigmata, in addition to microspined microstyles, a fact that confirms that archetypical rhabderemids are not related to Foraminospongia. However, microscleres are lacking in R. mona (de Laubenfels, 1934) and R. destituta, so they resemble Foraminospongia. Rhabderemia mona is a Caribbean sponge described from bathyal depths off Puerto Rico, used to erect the genus Stylospira for "sponges having no spicules other than peculiar spirally twisted styles" (de Laubenfels, 1934). This single specimen was later studied by Van Soest \& Hooper (1993) on a revision of the genus, who concluded that Stylospira should be considered a subgenus of Rhabderemia. Van Soest \& Hooper (1993) also described R. destituta from the Galapagos Islands, a second species matching de Laubenfels' diagnosis. Interestingly, apart from the lack of any kind of microscleres (even though de Laubenfels reported raphides for R. mona, not found by Van Soest \& Hooper, 1993), both species had smooth rhabdostyles, just as Foraminospongia, which is in contrast to most of the other Rhabderemia spp. Among the 30 known species of the genus, only $R$. stellata (Bergquist, 1961), $R$. spirophora (Burton, 1931), $R$. gallica (Van Soest \& Hooper, 1993), R. profunda (Boury-Esnault, Pansini \& Uriz, 1994), $R$. africana Van Soest \& Hooper, 1993, R. prolifera Annandale, 1915 and R. meirimensis Cedro, Hajdu \& Correira, 2013 have smooth rhabdostyles.

Unfortunately, there are no sequences available for $R$. mona nor $R$. destituta, so their potential relatedness with Foraminospongia cannot be addressed. However, it should be noted that both species have only rhabstosytles as megascleres, wich is in contrast to the heterogenous set of megascleres shown by Foraminospongia (styles, tylostyles, subtylostyles, rhabdostyles and oxeas). This seems a strong argument against congeneric relatedness with Foraminospongia. However, this issue should be properly addressed in the future when sequences of $R$. mona and $R$. destituta become available.

Order AXINELLIDA Lévi, 1953

Family AXINELLIDAE Carter, 1875

Genus Axinella Schmidt, 1862

\section{Axinella spatula Sitjà \& Maldonado, 2014}

(Fig. 8; Table 3)

\section{Material examined}


440

441

442

443

444

445

446

447

448

449

450

451

452

453

454

455

456

457

458

459

460

461

462

463

464

465

466

467

468

469

470

471

472

473

474

CFM-IEOMA-7364/i338_1A, CFM-IEOMA-7365/i338_1B and CFM-IEOMA-7366/i338_1C, St $11, \mathrm{~EB}, \mathrm{BT}$.

\section{Description}

Small, erect, cylindrical, and slightly flattened sponges, up to $3 \mathrm{~cm}$ height and 2-3 $\mathrm{mm}$ width (Figs. 8A-8C). Very hispid all along the body. Orange in life (Fig. 8A) and orange beige after preservation in $\mathrm{EtOH}$ (Fig. 8B).

\section{Skeleton}

As in Sitjà \& Maldonado (2014).

\section{Spicules}

Megascleres

Styles (Figs. 8D-8F): with a wide size range, rounded ends and sharp tips. Straight or slightly curved. The largest ones may be slightly sinuous, sometimes with subterminal swellings (Fig. 8D1). Rhabdostyle modifications are present in small and intermediateintermediate stages (Fig.

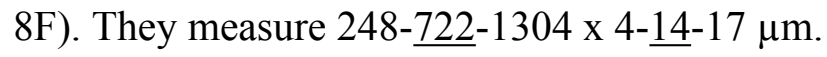

Oxeas: curved or bent, sometimes centrotylote (Figs. 8G-8K), with the curvature point at the center or displaced towards one of the extremities. Tips acerated. They measure 187-357-507 x 5-11-16 $\mu \mathrm{m}$.

\section{Microscleres}

Raphides in trichodragmata (Fig. 8C, detail), abundant and of the same morphology in all specimens. They measure $32-\underline{40}-56$ x 5---11 $\mu \mathrm{m}$.

\section{Ecology notes}

Found only on the north-eastern part of EB, at $152 \mathrm{~m}$ deep, on gravel bottoms with dead rhodoliths and with a large abundance of sponges such as P. (Petrosia) ficiformis (Poiret, 1789), P. (Petrosia) raphida Boury-Esnault, Pansini \& Uriz, 1994, P. (Strongylophora) vansoesti Boury-Esnault, Pansini \& Uriz, 1994 and several Tetractinellida.

\section{Remarks}

The specimens match well with those originaly described from the Alboran Sea. Balearic specimens are smaller (maximum height of $3 \mathrm{~cm}$ against maximum height of $10 \mathrm{~cm}$ in alboran specimens). Also, the size range of their styles and oxeas are not as wide as in Alboran specimens and trichodragmata of our specimens were always longer (Table 3 ).

Sitjà \& Maldonado (2014) described two phenotypes, according to the color acquired after preservation in EtOH (black or beige). Also, they found skeletal variations linked to each group, corresponding to a higher or lower presence of short styles, the morphology of the trichodragmata or the skeletal arrangement. The specimens collected here correspond only to the beige phenotype. 
475

476

477

478

479

480

481

482

483

484

485

486

487

488

489

490

491

492

493

494

495

496

497

498

499

500

501

502

503

504

505

506

507

508

509

With the present record, the species distribution widens towards the north-western Mediterranean Sea, since previously it was known only for the type's location, at the Alboran Island (Sitjà \& Maldonado, 2014).

\section{Phakellia robusta Bowerbank, 1866}

\section{Synonymised names.}

Phacellia robusta (Bowerbank, 1866) (misspelling of genus name)

\section{Material examined}

CFM-IEOMA-7367/i347 2, St 12, EB, BT; CFM-IEOMA-7368/i405 and CFM-IEOMA7369/i409, St 15, EB, BT; CFM-IEOMA-7370/i414_2, St 16, EB, BT; CFM-IEOMA-7371/i417, St 17, EB, BT; CFM-IEOMA-7372/i712, St 25, EB, BT; CFM-IEOMA-7373/i731, St 35, EB, RD; CFM-IEOMA-7374/POR760, St 20, south-western Cabrera Archipelago, GOC-73; CFMIEOMA-7375/POR762, St 21, south-western Cabrera Archipelago, GOC-73.

\section{Ecology notes}

The species was frequent at the studied area, being found in a broad depth range (150-750 m) on both rocky and sedimentary bottoms. In the trawl fishing grounds of the continental shelf around Mallorca and Menorca it was mostly found below $300 \mathrm{~m}$ deep, where most of the collected specimens were larger. In the seamounts of the Mallorca Channel, the species was common on gravel bottoms $150-170 \mathrm{~m}$ deep, where specimens tended to be very small $(1.5-3 \mathrm{~cm}$ in height) and in rocky outcrops and vertical walls, where sizes were intermediate (4-12 cm in height) and large (20-35 cm in height).

\section{Remarks}

The species is reported for the first time in the Mallorca Channel, being its second record at the Balearic Islands, where it was previously recorded by Santin et al. (2018) from the Menorca Channel. In the Mediterranean, it is also known from the Gulf of Lions (Vacelet, 1969), the Tyrrhenian Sea (Topsent, 1925), the Alboran Sea (Maldonado, 1992), the Strait of Sicily (Calcinai et al., 2013) and the Adriatic Sea (D'Onghia et al., 2015). Besides, the species has been reported from several localities of the North Atlantic including the Gulf of Cadiz (Sitjàà et al., 2019), the Azores Islands (Topsent, 1904), the Cantabrian Sea (Ferrer-Hernández, 1914) and the North Sea (Bowerbank, 1866).

\section{Phakellia ventilabrum (Linnaeus, 1767)}

\section{Synonymised names}

Halichondria ventilabrum (Linnaeus, 1767)

Phacellia ventilabrum (misspelling of genus name)

Phakellia ventilabra (ruling of ICZN)

Spongia strigose Pallas, 1766 (genus transfer \& junior synonym)

PeerJ reviewing PDF | (2021:04:59975:2:0:NEW 2 Jul 2021) 
510 Spongia venosa Lamarck, 1814 (genus transfer \& junior synonym)

511 Spongia ventilabra Linnaeus, 1767 (genus transfer \& incorrect spelling)

512 Spongia ventilabrum Linnaeus, 1767 (genus transfer)

$513 \quad$ Material examined

514 CFM-IEOMA-7376/i822_1, St 39, EB, ROV.

$515 \quad$ Ecology notes

516 The single specimen was collected on a rhodolith bed in the summit of the EB at $132 \mathrm{~m}$ deep

517 (Fig. 2C) where, according to preliminary analysis of ROV videos, it seems to be a rare species.

$518 \quad$ Remarks

519 This is the first report of the species at the Balearic Islands. The species has been widely reported

520 in the North Atlantic (e.g. Alvarez \& Hooper, 2002), to Greenland (Lundbeck, 1909; Hentschel,

521 1929) and Canada (Lambe, 1900). In the Mediterranean, it has been reported northern of the

522 Iberian Peninsula (Uriz, 1984), in the Alboran Sea (Maldonado, 1992) and Corsica (Vacelet,

523 1961).

524 Phakellia hirondellei Topsent, 1890

$525 \quad$ Synonymised names

526 Axinella hirondellei Topsent, 1890 (reverted genus transfer)

527 Phakellia robusta var. Hirondellei (Topsent, 1890) (status change)

528 Tragosia hirondellei (Topsent, 1890) (reverted genus transfer)

$529 \quad$ Material examined

530 CFM-IEOMA-7377/i353, St 13, EB, BT; CFM-IEOMA-7378/i623, St 33, AM, RD.

$531 \quad$ Ecology notes

532 The species was found at two stations of similar depth (135-147 m) in AM and EB. Both stations

533 are located at the border of the summit, an area that may be affected by enhanced water current

534 and an increase in nutrient and food supply (Samadi et al., 2007; Rogers, 2018). This could

535 explain the common presence of large erect sponges such as Poecillastra compressa

536 (Bowerbank, 1866) on stations located at these areas (personal observations).

$537 \quad$ Remarks

538 The species is reported for the first time in the Mallorca Channel, being its second record at the

539 Balearic Islands, where it was previously recorded by Santin et al. (2018) from the Menorca

540 Channel. In the Mediterranean Sea, it is also known in the north of the Balearic Sea (Uriz, 1984)

541 and in the Gulf of Lions, the Ligurian Sea and Corsica (Fourt et al., 2017) and the Alboran Sea

542 (Boury-Esnault, Pansini \& Uriz, 1994).

PeerJ reviewing PDF | (2021:04:59975:2:0:NEW 2 Jul 2021) 
543 Family HETEROXYIDAE Dendy, 1905

544 Genus Heteroxya Topsent, 1898

545 Heteroxya cf. beauforti

546 (Figs. 9, 10 and 11; Table 4)

$547 \quad$ Material examined

548 CFM-IEOMA-7381/i444, St 27, SO, RD; CFM-IEOMA-7382/i461, St 28, SO, RD; CFM-

549 IEOMA-7350/i487, St 30, SO, RD; CFM-IEOMA-7380/i726, St 35, EB, RD; CFM-IEOMA$5507379 /$ i727, St 35, EB, RD.

\section{$551 \quad$ Description}

552 Small encrusting patches, circular or irregular, up to $2 \mathrm{~cm}$ in diameter (Figs. 9A and 9B). Body

553 less than $1 \mathrm{~mm}$ thick. Consistency hard and slightly flexible. Hispidation visible to the naked

554 eye. Greyish in life and after preservation in $\mathrm{EtOH}$. No pores observed.

555

556

557

558

559

560

561

562

563

564

565

566

567

568

569

570

571

572

573

574

575

\section{Skeleton}

A basal spongin layer adheres to the substrate and allows the whole body to be peeled-off with a scalpel. Just upon this layer there are Oxea II running parallel to the substrate. The choanosome has low spicule content. Choanosomal chambers are relatively well developed in the thicker parts of the sponge (Figs. 10A and 10B). Thick areas also have ascending tracts of Oxea II, with Oxea II placed in between. The choanosomal tracts are not present in the thinner areas (Fig. 10C). The basal layer and the choanosome have abundant circular bodies 3-9 $\mu \mathrm{m}$ in diameter, dark or transparent (Fig. 10B). The ectosome is constructed by a dense palisade of Oxea II, perpendicular to the surface, with Oxea I placed in the same perpendicular position, emerging towards the exterior. Long styles are found here and there outcrossing the ectosome and causing the hispidation.

\section{Spicules}

Oxeas I (Fig. 11A): may be gently curved or bent in the middle, with sharp tips. They measure 319-ㅆ2-623 x 7-10-15 $\mu \mathrm{m}$.

Oxeas II (Figs. 11B): gently curved, curved or bent in the middle. Some stylote modifications present. Many with teratogenic parts like bifid tips, swellings or poliaxonal modifications (Figs. $11 \mathrm{C}$ and 11D). They measure 104-198-293 x 3-ㄱ-10 $\mu \mathrm{m}$.

Hispidating styles (Fig. 11E-E2): very long and thin, curved, with round ends and sharp tips. Most broken, only three complete from specimen CFM-IEOMA-7381/i444, measuring 1151$3502 \times 8-14 \mu \mathrm{m}(\mathrm{n}=3)$.

\section{Ecological notes}


576 The species has been collected on smooth basaltic rocks between 270 and $325 \mathrm{~m}$ deep at SO and 577 EB, where it seems to be rather common. Mostly associated with other minute encrusting

578 sponges like Hamacantha spp. or Bubaris spp.

$579 \quad$ Genetics

580 Sequences of COI Folmer fragment and the $28 S \mathrm{C} 1-\mathrm{D} 2$ domains were obtained from the 581 specimen CFM-IEOMA-7380/i726. Both sequences were deposited at the Genbank, under the 582 accession numbers MW858350 and MW881150, respectively.

Remarks

584

585

586

587

588

589

590

591

592

593

594

595

596

597

598

599

600

601

602

603

604

605

606

607

608

609

610

611

The genus Heteroxya contains two species, H. corticata Topsent, 1898 and H. beauforti Morrow, 2019. Heteroxya corticata is the type of the genus, known only from deep waters (1200-1600 m) of the Azores Archipelago. The species has two categories of oxeas, both microspined, and lacks styles. Conversely, $H$. beauforti is known from slightly shallower waters of Ireland (630-1470 $\mathrm{m})$, has smooth oxeas and posses long hispidation styles (Table 4). The genus was reviewed by Morrow et al. (2019), that sequence the COI of both holotypes. They found no differences between the COI of $H$. corticata and $H$. beauforti but conclude that morphological differences were enougth to consider both as different species.

Morphologically, our material is more related to $H$. beauforti due to the abscense of microspined oxeas and the presence of hispidation styles. We have found circular bodies embedded in the choanosome and the basal layer, which can be equivalent to the spherulous cells found in $H$. beauforti (Morrow et al., 2019). However, oxea I, oxea II and styles are markedly shorter and thinner in our material than those of $H$. beauforti. Those differences may be a result of depth, nutrient, or temperature differences. On the other hand, the COI sequence of our material is identical to the sequences of $H$. corticata and $H$. beauforti. We have sequenced the 28S C1-D2 domains, but there are no published sequences to compare. Considering the lack of genetic differences and the affinity of our material to $H$. beauforti, here we believe that erecting a new species is not justified. Future works using other markers will clarify if $H$. cf. beauforti and $H$. beauforti are conspecific, or if $H$. cf. beauforti is a different species.

Heteroxya cf. beauforti represents the first record of a species belonging to the genus Heteroxya in the Mediterranean Sea.

Family STELLIGERIDAE Lendenfeld, 1898

Genus Paratimea Hallmann, 1917

Paratimea massutii sp. nov.

(Fig. 12; Table 5)

\section{Diagnosis}

Massive ovoid sponge with oxeas as megascleres and oxeas as auxiliary spicules. Centrotylotism occasionally present in both. Oxyasters smooth. 
612

613

614

615

616

617

618

619

620

621

622

623

624

625

626

627

628

629

630

631

632

633

634

635

636

637

638

639

640

641

642

643

644

\section{Etimology}

Dedicated to Professor Enric Massuti, for his contribution to the knowledge of the benthic communities of the Balearic Islands.

\section{Material examined}

Holotyope: CFM-IEOMA-7383/i403, St 15, EB, BT.

Paratype: CFM-IEOMA-7384/i420, St 17, EB, BT.

\section{Description}

Both specimens are massive, subspherical, the largest (holotype, CFM-IEOMA-7383/i403; Fig. 12A) measuring about $5 \mathrm{~cm}$ in diameter, having a lobose surface with grooves and humps. Skin of a leathery touch, hispid only in the grooves. Color in life differing between the upper and the lower faces, the former having the first a brownish tinge while the latter a whitish to beige shade (Fig. 12A and 12B). After preservation in EtOH the whole body turns homogeneous vanilla cream (Fig. 12C). Both specimens have 4-6 circular oscula, 1-2 mm in diameter, scattered throughout the body. However, the holotype also has a main large and circular osculum, about 1 $\mathrm{cm}$ in diameter, on the upper side. Both specimens expelled a considerable amount of mucus when collected.

\section{Skeleton}

Ectosome not separable from the choanosome, formed by a dense crust of oxyasters and tangential principal and auxiliary oxeas. Choanosome composed of irregularly arranged oxeas and oxyasters, although radial bundles of large oxeas are present in the periphery, supporting the ectosome (Fig. 12D).

\section{Spicules}

\section{Megascleres}

Oxea I (Fig. 12E): robust and fusiform, some double bent, sometimes slightly centrotylote. They measure 910-1390-1711 x 11-21-33 $\mu \mathrm{m}$.

\section{Auxiliary spicules}

Oxea II (Fig. 12F): uncommon. Bent or slightly sinuous, sometimes centrotylote. They measure 469-746-1088 x 3---10 $\mu \mathrm{m}$.

\section{Microscleres}

Oxyasters (Figs. 12G-12J): with long, smooth and sharp rays. About 7-25 rays, occasionally less. Smaller ones tend to have more rays than larger ones, measuring 25-38-57 $\mu \mathrm{m}$. Occasionally, some two-rayed oxyaster present.

\section{Ecological notes}


645 Found at two stations on calcareous gravel bottoms on the summit of EB (155 and $167 \mathrm{~m}$ deep), 646 which was dominated by sponges such as Hexadella sp., Phakellia robusta and different species 647 of the order Tetractinellida. A large number of the brachiopod Gryphus vitreus (Born, 1778) and 648 echinoderms were also recorded.

\section{Genetics}

650

651

652

653

654

655

656

657

658

659

660

661

662

663

664

665

666

667

668

669

670

671

672

673

674

675

676

677

678

679

680

681

682

683

Sequences of COI Folmer fragment was obtained from the Holotype (CFM-IEOMA-7383/i403) and deposited at Genbank under the accession number MW858351.

Remarks (see Table 5 for a detailed comparison with other Paratimea spp.)

Morphologically, the species resembles Paratimea oxeata Pulitzer-Finali, 1978, a Mediterranean species reported at rocky and muddy bottoms, at 35-60 and $110 \mathrm{~m}$ deep, respectively (PulitzerFinali, 1978; Bertolino et al., 2013), and at submarine caves at 15-20 m deep (Morrow et al., 2019). However, P. massutii sp. nov. is massive, a feature only shared with the cave specimen (S153) reported by Morrow et al. (2019). Notwithstanding, in P. massutii sp. nov. oxeas I are thicker, oxeas II longer and oxyasters slightly larger and with more actines (2-25 versus 4-12). A comparison of the COI sequences between the holotype of $P$. massutii sp. nov. and the cave specimen confirms those morphological differences, with $15 \mathrm{bp}$ differences and a $p$-distance of $2 \%$. On the other side, both the holotype and the specimens studied by Bertolino et al. (2013) differ from $P$. massutii sp. nov. in being cushion shaped or encrusting and having smaller oxeas. Unfortunately, no sequences of Bertolino et al. (2013) specimens are available to compare. Paratimea massutii sp. nov. is also similar to P. hoffmannae Morrow \& Cárdenas, (2019), a North Atlantic species found in Norway and Ireland that is also massive and subspherical and has oxeas as both megascleres and auxiliary spicules. However, the large oxeas are much larger and thicker than in P. massutii sp. nov., in contrast to the auxiliary spicules, which are shorther and thinner. Also, the oxyasters of $P$. hoffmannae are larger and with less actines. As for $P$. oxeata, COI sequences between $P$. hoffmannae and $P$. massutii sp. nov. are notably distant, with $13 \mathrm{bp}$ differences and a $p$-distance of $2 \%$. A similar case happens with P. lalori Morrow, 2019 from Ireland. This species is also massive-subspherical with oxeas as main megascleres and auxiliary spicules. Just as in $P$. hoffmannae, megascleres of $P$. lalori are longer and thicker than those of $P$. massutii sp. nov., auxiliary spicules are shorter and thinner and oxyasters slightly larger and with fewer actines.

Paratimea massutii sp. nov. also differs from the other Mediterranean Paratimea spp. as follows: P. loricata (Sarà, 1958a) is encrusting, has much smaller oxeas I and oxeas II and two categories of oyasters, and bears tylostyles; P. pierantonii (Sarà, 1958b) is cushion-shaped, has styles and subtylotyles as megascleres, longer, thicker, and never centrotylote oxeas II and smaller oxyasters.

Also, $P$. massutii sp. nov. differs from North-eastern Atlantic Paratimea spp. as follows: $P$. constellata is cushion shaped, has tylostyles and smaller oxyasters; P . arbuscula (Topsent, 1928), is arbustive, lacks auxiliary spicules and has smaller, acanthose oxyasters; Paratimea duplex (Topsent, 1927) is cushion shaped, has much larger oxeas I, bears styles, subtylostyles, 
684 and two categories of oxyasters; P. loennbergi (Alander, 1942) is thinly encrusting, has

685 tylostyles and smaller oxyasters.

686 This is the first report of the genus Paratimea in the Balearic Islands, and the deepest record in 687 the Mediterranean Sea.

688 Order BUBARIDA Morrow \& Cárdenas, 2015

689 Family BUBARIDAE Topsent, 1894

690 Genus Rhabdobaris Pulitzer-Finali, 1983

691 Rhabdobaris implicata Pulitzer-Finali, 1983

$692 \quad$ Synonymised names

693 Cerbaris implicatus (Pulitzer-Finali, 1983)

$694 \quad$ Material examined

695 CFM-IEOMA-7385/i338_2_1, St 11, EB, BT; CFM-IEOMA-7386/i698, St 34, EB, RD. $696 \quad$ Ecological notes

697 Uncommon sponge found at two stations on the EB summit at 117 and $152 \mathrm{~m}$ deep, growing on 698 living rhodoliths. Both stations were rich in massive demosponges, including large

699 Tetractinellids, Petrosia (Petrosia) ficiformis and P. (Strongylophora) vansoesti.

$700 \quad$ Remarks

701 This is the third time that the species is recorded, previously only known from the holotype

702 collected in Corsica (Pulitzer-Finali, 1983) and the neotype collected at the Alboran Island (Sitjà

$703 \&$ Maldonado 2014).

704 Order DESMACELLIDA Morrow \& Cárdenas, 2015

705 Family DESMACELLIDAE Ridley \& Dendy, 1886

706 Genus Dragmatella Hallman, 1917

707 Dragmatella aberrans (Topsent, 1890)

708 (Fig. 13; Table 6)

$709 \quad$ Material examined

710 CFM-IEOMA-7387/i52_b1, St 2, SO, BT; CFM-IEOMA-7388/i175, St 5, EB, BT.

711 Description (modified from Hooper \& Van Soest, 2002)

712 Small hollow sponge encrusting on stones or corals. Up to $2 \mathrm{~cm}$ in diameter. Whitish grey in life 713 and after preservation in EtOH. Surface smooth, but provided with long thin, pointed fistules 714 (Fig. 13A and 13B). 


\section{Skeleton}

716 Ectosome composed of parallel tight tracts of styles, disposed in 4-5 layers of 30-50 $\mu \mathrm{m}$ in 717 thickness (Fig. 13C). The raphides, sometimes grouped in trichodragmata, are scattered in the 718 ectosomal and choanosomal tracts. Choanosome is cavernous (Fig. 13D), with tracts of styles, 719 about $200 \mu \mathrm{m}$ long, verging from a basal layer towards the ectosome.

720 Spicules

721 Megascleres

722 Styles (Figs. 13E and 13E1) fusiform, tappering towards the head, slightly or abruptly bent. They 723 measure 349- $\underline{546}-676 \times 6-\underline{10}-15 \mu \mathrm{m}$.

724

725

726

727

728

729

730

731

732

733

734

735

736

737

738

739

740

741

742

743

744

745

746

747

748

749

\section{Microscleres}

Raphides (Figs. 13F and 13F1) abundant, straight, with an irregular shaft and one end hook-

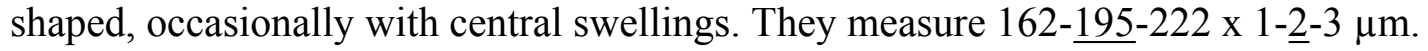

\section{Ecological notes}

Abundant species on sedimentary bottoms, with rests of calcareous shells and corals, found in $\mathrm{SO}, \mathrm{AM}$ and $\mathrm{EB}$ and, to a lesser extent, on trawl fishing grounds of the continental shelf off Mallorca (between 138 and $362 \mathrm{~m}$ deep). On the same bottoms other small encrusting sponges such as Hamacantha spp. or Bubaris spp., the pedunculated Rhizaxinella pyrifera (Delle Chiaje, 1828) and Thenea muricata (Bowerbank, 1858), the brachiopod Gryphus vitreus (Born, 1778) and small crustaceans are to be found.

\section{Remarks}

The species is easily distinguished by its hollow body and the possession of both styles and raphides. The latter have singular hook-shaped ends, a feature that had not been recorded before, and that is similar to the raphides found in some species of the genus Dragmaxia (Order Axinellida) (Hooper \& Van Soest, 2002). No molecular data are available for Dragmatella, but a phylogenetic relationship with Dragmaxia is unlikely, given the possession of styles and the skeletal arrangement of both genera. Therefore, hook-shaped raphide are probably homoplasic.

This is the first report of the species in the Balearic Islands. In the Mediterranean Sea it has been recorded at the Gulf of Lions (Vacelet, 1969), Corsica (Pulitzer-Finali, 1983) and the Alboran Sea (Boury-Esnault, Pansini \& Uriz, 1994; Sitjà \& Maldonado, 2014). In the North Atlantic Ocean, this species has been recorded at several locations, including the coast of Portugal (Topsent, 1895), the Josephine Bank (Topsent, 1928) and the Cantabric Sea (Topsent, 1890).

Order HAPLOSCLERIDA Topsent, 1928

Family CHALINIDAE Gray, 1867

Genus Haliclona Grant, 1841

Subgenus Soestella De Weerdt, 2000

PeerJ reviewing PDF | (2021:04:59975:2:0:NEW 2 Jul 2021) 
750

751

752

753

754

755

756

757

758

759

760

761

762

763

764

765

766

767

768

769

770

771

772

773

774

775

776

777

778

779

780

781

782

783

\title{
Haliclona (Soestella) fimbriata Bertolino \& Pansini, 2015
}

\author{
Material examined
}

CFM-IEOMA-7389/i825_1, St 40, EB, ROV.

\section{Ecological notes}

The species was spotted regularly at the rhodolith beds of the EB summit, between 134 and 150 $\mathrm{m}$ deep. However, it was less abundant and not forming patches, as occurs in some areas of the Gulf of St. Eufemia in the Tyrrhenian Sea, where Bertolino et al. (2015) reported densities of $7.4 \pm 0.7$ specimens $/ \mathrm{m}^{2}$.

This is the second report of the species, previously recorded only at the Gulf of St. Eufemia (southern Tyrrhenian Sea; Bertolino et al., 2015), expanding its distribution range towards the westernmost part of the Mediterranean Sea.

Family PETROSIIDAE Van Soest, 1980

Genus Petrosia Vosmaer, 1885

Subgenus Strongylophora Dendy, 1905

Petrosia (Strongylophora) vansoesti Boury-Esnault, Pansini \& Uriz, 1994

\section{Material examined}

CFM-IEOMA-7390/i192_A and CFM-IEOMA-7391/i192_B, St 6, EB, BT; CFM-IEOMA7392/i313_P and CFM-IEOMA-7393/i313_G, St 11, EB, BT; CFM-IEOMA-7394/i351, St 13, EB, BT; CFM-IEOMA-7395/i694, St 34, EB, RD.

\section{Ecological notes}

Large amounts of $P$. $(S)$ vansoesti were collected from various stations in the summit of the EB, suggesting that it is an important species inhabiting Mediterranean seamounts and probably a habitat builder that confers three-dimensionality to the seafloor. The species was found from 116 to $152 \mathrm{~m}$ deep, on stations with living and dead rhodoliths and gravels, associated with large sponges such as $P$. (P.) ficiformis and some tetractinellids and halichondrids. Many groups of invertebrates, such as small crustaceans and echinoderms, were also observed at these stations.

\section{Remarks}

This is the first record of the species in the western Mediterranean. The type locality is the Gulf of Cadiz, in the north-eastern Atlantic. In the Mediterranean it has been recorded in marine caves at both the Ionian Sea (Costa et al., 2019) and the Aegean Sea (Gerovasileiou \& Voultsiadou, 2019). It has been also recorded at the Levantine Sea, living on rocks at depths shallower than 3 $\mathrm{m}$ (Evcen \& Çinar, 2018). On the Balearic Islands, the species has only been collected in EB.

Subgenus Petrosia Vosmaer, 1885

Petrosia (Petrosia) raphida Boury-Esnault, Pansini \& Uriz, 1994 
784

785

786

787

788

789

790

791

792

793

794

795

796

797

798

799

800

801

802

803

804

805

806

807

808

809

810

811

812

813

814

815

816

817

818

819

(Fig. 14; Table 7)

\section{Material examined}

CFM-IEOMA-7396/POR406, St 1, south-east of Menorca, GOC-73; CFM-IEOMA7397/i178_3, St 5, EB, BT; CFM-IEOMA-7451/i242 and CFM-IEOMA-7398/i254_2, St 8, AM, BT; CFM-IEOMA-7399/i305, St 10, AM, BT; CFM-IEOMA-7400/i312, St 11, EB, BT.

\section{Description}

Massive sponges, the largest collected specimen measuring about $4.5 \mathrm{~cm}$ in diameter and $2.5 \mathrm{~cm}$ in height (Fig. 14A). Whitish in life, beige after preservation in EtOH. Consistency hard, slightly crumbly. Surface rough due to minute conules, although in some specimens this is less obvious. There are 1 to 6 circular oscules of 2-5 mm diameter.

\section{Skeleton}

Ectosome forming a detachable crust not evident to the naked eye, tightly adhering to the choanosome, and made of irregular net of polygonal to triangular meshes. Meshes are constituted by one or two spicules. Spongin is present and fully embedded with raphides.

Choanosome (Figs. 14B and 14C) with an isotropic net of pauci-spicular spicule tracts covered by spongin, forming roundish meshes. These meshes are abundantly embedded by raphides. The tracts tend to condense towards the surface, supporting the ectosome.

\section{Spicules}

Oxeas (Figs. 14D and 14E): curved, with mucronated ends. Some polyaxonal modification in the shaft and ends may be present. They measure $242-\underline{372}-450 \times 9-\underline{15}-19 \mu \mathrm{m}$, although underdeveloped stages (196-368/3-8 $\mu \mathrm{m})$ are present. Styles and strongyles of the same length and width as the oxeas, present but scarce.

Raphides (Figs. 14F and 14F1): slightly curved, most minutely spined, although smooth ones are also present (Fig. 14G). They measure 62- $\underline{77-95} \times 1-\underline{2}-2 \mu \mathrm{m}$.

\section{Ecological notes}

This species is very common in both AM and EB at the 101-152 $\mathrm{m}$ bathymetric range, and has been also found at the same depths off the southern coast of Menorca (Table 7). It can be found as a free-living sponge or growing attached to small fragments of calcareous sediments. However, it is also commonly found as an epibiont of other sponges and rhodoliths. The species seems to prefer massive specimens of Hexadella sp. and Halichondria sp. as substrate.

\section{Remarks}

The species is easily recognized due to the presence of characteristic spined raphides, added to other Petrosid features such as the skeletal architecture and the morphology of the oxeas.

Remarkably, the specimens described in this study differ from the two previous reports in having much smaller oxeas (see below in brackets). This could be explained by the scarcity of nutrients in waters around the Balearic Islands, the bathymetric range in which the specimens were 
820 collected and/or differences in water temperature, seasonal variability and population phenotypes

821 (Simpson, 1978; Valisano et al., 2012). These variables could also be the cause of differences in

822 the morphology of the megascleres already noted by Sitjà et al., (2019) when comparing their

823 material with the holotype. In the specimens from the Gulf of Cadiz (north-eastern Atlantic),

824 strongyles were rare. Instead, megascleres consisted mostly of oxeas with stepped tips and some

825 occasional stylote or strongylote modifications. This last feature is shared with specimens of the

826 Balearic Islands but not with the holotype, whose spicules have mostly strongylote extremities.

827 These differences may be related to variations in nutrient regimes between the Balearic Islands

828 and these areas (Santinelli, 2015).

829 This is the first record of the species in the Mediterranean, but at a considerably shallower depth 830 (101-152 m) than in the north-eastern Atlantic, where the species was reported at $580 \mathrm{~m}$ deep in 831 the Strait of Gibraltar (Boury-Esnault, Pansini \& Uriz, 1994) and at 530-575 m deep in the Gulf 832 of Cadiz (Sitjà et al., 2019) (Table 7).

833 Family PHLOEODICTYIDAE Carter, 1882

834 Genus Calyx Vosmaer, 1885

\section{Calyx cf. tufa}

836 (Fig. 15; Table 8)

\section{Material examined}

CFM-IEOMA-7403/i525, St 24, AM, BT; CFM-IEOMA-7401/i75, St 3, AM, BT; CFMIEOMA-7402/i515, St 23, AM, BT.

\section{Description}

841

842

843

844

845

846

847

848

849

850

851

852

853

854

Large, massive and semicircular sponges, up to $15 \mathrm{~cm}$ in diameter and $5 \mathrm{~cm}$ in height (Fig. 15A). Surface smooth to the touch; consistency stony hard and uncompressible. Choanosome slightly friable and cavernous. Color in life beige, with pink tints in the upper side of the body and whitish beige in the lower. It became homogeneous brownish beige after preservation in EtOH. Two to three large and circular oscula are located in the upper side of the body, measuring 1.3 $\mathrm{cm}$ in diameter. Ostia grouped in poral areas of the ectosome (Fig. 15B).

\section{Skeleton}

The ectosome (Fig. 15C) is formed by a crust of tangential spicules, forming triangular paucispicular meshes that become less dense at the poral areas. Spongin present but not abundant, with a granular appearance due to the presence of spherulous cells filled with granules (Fig 15C, arrow).

The choanosome (Figs. 15D and 15E) is mostly composed of a rather isotropic, unispicular net of spicules.

\section{Spicules}


855 Oxeas (Figs. 15F and 15G): slightly curved, with stepped or slightly mucronate points (Fig. 856 15G1) and rarely bent in the middle. They measure 132-173-206 x 4-1-9 $\mu \mathrm{m}$.

857

858

859

860

861

862

863

864

865

866

867

868

869

870

871

872

873

874

875

876

877

878

879

880

881

882

883

884

885

886

887

888

889

890

891

892

893

\section{Genetics}

Sequences of COI Folmer and 28S C1-D2 domains were obtained from the specimen CFMIEOMA-7403/i525 and deposited in Genbank under the accession numbers MW858349 and MW881149, respectively.

\section{Ecological notes}

The species was found only at the summit of AM between 105 and $114 \mathrm{~m}$ deep, associated with rhodolith beds. It has also been found amongst with diverse set of sponges, including large Tetractinellids and other sponges such as Hexadella sp., Axinella spp. or P. (P.) raphida, as well as among many other invertebrates typically inhabiting the rhodolith beds, like small crustaceans and echinoderms. The pink coloration of its upper skin is probably caused by symbiotic cyanobacteria, as commonly happens in other Haplosclerids (Rützler, 1990).

\section{Remarks}

There are only two reported species of Calyx from the north-eastern Atlantic and the Mediterranean: Calyx nicaeensis (Risso, 1827) and C. tufa (Ridley \& Dendy, 1886). The first is the type species of the genus, which is a well-known species characterized by its growing habit (vasiform), blackish color and large size. This species has been widely reported at both the western and eastern Mediterranean in infralittoral and circalittoral bottoms at 3-50 m deep (Trainito et al., 2020). Calyx cf. tufa clearly differs from C. nicaeensis in morphology (massive vs. vasiform, respectively), genetics (COI: 11 bp difference; 28S: 43 bp difference) and bathymetry (105-114 vs. 3-50 m, respectively). Calyx tufa is only known from its type locality at Cape Verde (Dendy, 1886) and from the Cantabrian Sea (Topsent, 1892). The species that we studied shares many characteristics with $C$. cf. tufa, including external morphology, consistency, and skeletal architecture. Unfortunately, the only description available is the one provided by Dendy (1886), which is too general and matches with the characters of many other Calyx spp. (e.g., Calyx podatypa de Laubenfels 1934; Calyx magnoculata Van Soest, Meesters \& Becking, 2014; Calyx nyaliensis Pulitzer-Finali, 1993). The large distances between the reports of C. tufa and $C$. cf. tufa, the strong genetic barriers that separate the two records (the Strait of Gibraltar and the Almeria-Oran front), the generalized low dispersive potential of some sponge species (Riesgo et al., 2019; Griffiths et al., 2021) and the difference of habitats, are reasons that may suggest that the species that we report here is different from $C$. tufa. Moreover, no intermediate geographical findings have been reported, which would be expected if there was conspecificity (Topsent, 1928; Maldonado, 1992; Boury-Esnault, Pansini \& Uriz, 1994; Sitjà \& Maldonado, 2014; Sitjà et al., 2019). It should be noted that $C$. cf. tufa is a very large, massive, and easily recognizable sponge, which cannot be easily go unnoticed. However, considering that we did not study the holotype and that no genetic sequences of $C$. tufa are available, the possible conspecificity of $C$. cf. tufa with $C$. tufa cannot be completely assessed. Therefore, future work comparing the holotype of $C$. tufa may be needed to determinate if both species are different or

PeerJ reviewing PDF | (2021:04:59975:2:0:NEW 2 Jul 2021) 
894 conspecific. Considering the mentioned lack of data, here we use the more conservative choice 895 by assigning the present record to $C$. cf. tufa.

896 Order POECILOSCLERIDA Topsent, 1928

897 Family MYXILLIDAE Dendy, 1922

898 Genus Melonanchora Carter, 1874

899 Melonanchora emphysema (Schmidt, 1875)

900 (Fig. 16)

$901 \quad$ Synonymised names

902 Desmacidon emphysema Schmidt, 1875 (genus transfer)

$903 \quad$ Material examined

904 CFM-IEOMA-7404/i573, St 31, AM, RD.

905 Description

906 Hollow sponge with a detachable, smooth and paper-like ectosome provided with fistulas (Fig.

907 16A). About $2 \mathrm{~cm}$ in diameter. The choanosome is loose and includes sediment. Greyish white in 908 life and after preservation in $\mathrm{EtOH}$.

$909 \quad$ Skeleton

910 As in the previous records of the species (Schmidt, 1785; Vacelet, 1969; Pulitzer-Finalli, 1983).

$911 \quad$ Spicules

912 Megascleres

913 Tylotes (Figs. 16B and 16C) slightly curved, with roundish ends. Their length tends to be

914 inversely related to their thickness. They measure 359-446-556 x 5-ㅁ-11 $\mu \mathrm{m}$.

915 Microscleres

916 Spheranchoras (Fig. 16D and 16E) of usual morphology, but uncommon. They measure 36-40-

$91746 \times 14-\underline{19}-23 \mu \mathrm{m}(\mathrm{n}=11)$.

918 Arcuate isochela I (Fig. 16F) with well-developed fimbriae and spatulated and bifid alae. They 919 measure $29-\underline{42}-47 \mu \mathrm{m}$.

920 Arcuate isochela II (Fig. 16G) similar to isochela I, but with rounded alae. They measure 14-18$92121 \mu \mathrm{m}$.

$922 \quad$ Ecological notes

923 The single specimen was found in AM, on a rhodolith bed between 104 and $138 \mathrm{~m}$ deep. It was

924 growing upon a large rhodolith, which was extensively epiphyted by encrusting, massive- 
925 encrusting or pedunculated sponges (like Hamacantha sp. or Jaspis sp.) or pedunculated

926 Axinellids.

$927 \quad$ Remarks

928 The specimen matches well with the previous records of the species, both in external

929 morphology, spicules and skeletal arrangement. This is the third record of this species in the

930 Mediterranean, where it was recorded in the canyon de Cassidaigne in the Gulf of Lions

931 (Vacelet, 1969) and Corsica (Pulitzer-Finali, 1983). In the North-Atlantic, it has been reported at

932 several localitions: the type locality at Norway (Schmidt, 1875), the east Greenland shelf

933 (Lundbeck, 1905), the Faroe Plateau (Hentschel, 1929) and the north coast of the Iberian

934 Peninsula (Solorzano, 1990). The vast distances between the Mediterranean and the North

935 Atlantic reports (being the closest off northern Iberian Peninsula), and the lack of intermediate

936 reports in well-studied areas such as the Alboran Sea, may indicate that Mediterranean and North

937 Atlantic M. emphysema are different species, as already discussed by Vacelet (1969).

938 Order POLYMASTIIDA (Morrow \& Cárdenas, 2015)

939 Family POLYMASTIIDAE (Gray, 1867)

940 Genus Polymastia (Lammarck, 1815)

941 Polymastia polytylota Vacelet, 1969

942 (Fig. 17; Table 9)

$943 \quad$ Material examined

944 CFM-IEOMA-7405/i810, St 39, AM, ROV.

$945 \quad$ Description

946 Rounded sponge, $2 \mathrm{~cm}$ high and wide, with two conical papillas $(0.5 \mathrm{~cm}$ high and $3 \mathrm{~mm}$ wide $)$

947 placed on the upper side of the body (Figs. 17A and 17B). Consistency hard and slightly

948 compressible. Surface smooth to the touch, but microhispid under the stereomicroscope. Cream

949 color before and after preservation in $\mathrm{EtOH}$, with a darker choanosome. The specimen suffered a

950 contraction after collection. In situ the sponge was $4.5 \mathrm{~cm}$ in height and $4 \mathrm{~cm}$ in width, being

951 looser and with its surface full of visible ostia (Fig. 2A).

\section{$952 \quad$ Skeleton}

953 As in the previous reports of the species (Vacelet, 1969; Pulitzer-Finali, 1983; Boury-Esnault,

954 1987; Boury-Esnault, Pansini \& Uriz, 1994).

$955 \quad$ Spicules

956 Principal tylostyles (Figs. 17C and 17C1): straight and fusiform, with several tyles in the

957 proximal half part of the shaft. They measure 438- $\underline{909}-1154$ x 8-11-15 $\mu \mathrm{m}$. 
958 Intermediary tylostyles (Figs. 17D and 17D1): fusiform, with a rounded head, often showing a

959 vesicle. They measure $308-\underline{443}-586$ x 6-7-9 $\mu \mathrm{m}$.

960 Ectosomal tylostyles (Fig. 17E and 17E1): slightly curved. They measure 121- $\underline{166-200} \times \mathbf{2}-\underline{3}-5$

$961 \mu \mathrm{m}$.

\section{$962 \quad$ Ecology notes}

963 Only one specimen collected in the northern part of the AM, between 352 and $465 \mathrm{~m}$ deep, on a 964 rocky bottom characterized by enhanced water movement, with several large Phakellia spp,

965 Pachastrella spp and Poecillastra compressa, as well as other Polymastia cf. polytylota.

966 Although the present specimen was the only collected, its easy identification and the other

967 sighthings during ROV transects may suggest that this sponge is quite common in some areas of

968 the Mallorca Channel.

\section{Remarks}

970

971

972

973

974

975

976

977

978

979

980

981

982

983

984

985

986

987

988

989

990

991

The present specimen matches with the previous descriptions of the species in external morphology, skeletal architecture and spicule morphometrics. The only difference is that our specimen has two papillae instead of one. The Fig. 2A shows the first in-situ image of this species.

This is the first record of this species at the Balearic Islands. In the Mediterranean it is known from the type locality at the Gulf of Lions (Vacelet, 1969), the Ligurian Sea (Vacelet, 1969;

Pulitzer-Finali, 1983) and the Alboran Sea, while it has been also reported at the Gulf of Cadiz in the north-eastern Atlantic (Boury-Esnault, Pansini \& Uriz, 1994).

Genus Pseudotrachya Hallmann, 1914

\section{Pseudotrachya hystrix (Topsent, 1890)}

(Fig. 18; Table 10)

\section{Material examined}

CFM-IEOMA-7406/i303_A, St 19, AM, RD; CFM-IEOMA-7407/i613, St 32, AM, RD.

\section{Description}

Roundish and pad-like encrusting sponge, up to $2 \mathrm{~cm}$ diameter and $3 \mathrm{~mm}$ in height (Fig. 18A). Coloration beige in life and whitish after preservation in EtOH. Very hispid surface. Consistency hard and only slightly compressible. No papillae, oscula and ostia inconspicuous.

Skeleton (modified from Plotkin et al., 2013)

Single layered cortex (palisade of microxeas). Main choanosomal skeleton of principal anisoxeas radially arranged, echinating the surface and auxiliary choanosomal skeleton of microxeas (Figs. $18 \mathrm{~B}$ and $18 \mathrm{~B} 1)$.

Spicules 
992 Anisoxeas (Figs. 18C and 18C1): straight and robust, with stepped ends. Intermediary stages 993 between oxeas and styles present. Anisoxea size differs between specimens, measuring 834-

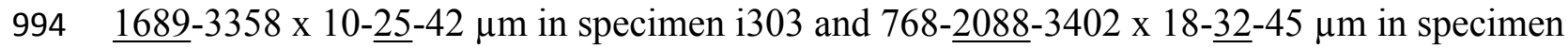
995 i613. Small and immature anisoxeas also present, but very scarce, about 500/10 $\mu \mathrm{m}$.

996 Microxeas (Fig. 18D): fusiform and measuring 156-185-217 x 4- $\underline{5-6} \mu \mathrm{m}$ in specimen $i 303$ and 997 152-203-270 x 3-5-6 in specimen 1613.

998

999

1000

1001

1002

1003

1004

1005

1006

1007

1008

1009

1010

1011

1012

1013

1014

1015

1016

1017

1018

1019

1020

1021

1022

1023

1024

1025

1026

1027

\section{Ecology notes}

In addition to the two specimens described above, several other $P$. hystrix were collected from rocky slopes of AM and EB, between 195 and $302 \mathrm{~m}$ deep, suggesting that this species could be quite common in the Mallorca Channel seamounts. The species is found at rocky slopes, together with other small encrusting sponges such as Hamacantha spp., Bubaris spp. and the Hexactinellid Tretodyctium sp.

\section{Remarks}

This is a well-known species, characterized by their enormous megascleres with unequal tips (oxeote to stylote), and their small microxeas. Variations in the size of megascleres have been previously documented and may be related to ecological factors such as depth, nutrient availability, or temperature (Maldonado et al., 1999). However, due to their size, the largest megascleres were mostly broken, which could be a reason for the lack of reports on sizes 5000$7000 \mu \mathrm{m}$ (Table 10).

This is the first record of the species in the Balearic Islands, expanding its geographical distribution in the Mediterranean, where it was previously reported at the Tyrrhenian Sea (Sarà, 1959), the Ligurian Sea (Pulitzer-Finali, 1983), the Gulf of Lions (Vacelet, 1969) and the Alboran Sea (Booury-Esnault, Pansini \& Uriz, 1994).

Order TETHYIDA Morrow \& Cardenas, 2015

Family HEMIASTERELLIDAE Lendenfeld, 1889

Genus Hemiasterella Carter, 1879

\section{Hemiasterella elongata Topsent, 1928}

\section{Material examined}

CFM-IEOMA-7408/i149_4, St 7, EB, RD; CFM-IEOMA-7409/i337, St 11, EB, BT; CFMIEOMA-7410/1531, St 24, AM, BT; CFM-IEOMA-7411/POR1066, St 36, south-western Cabrera Archipelago, GOC-73.

\section{Ecological notes}

This species was found at meshophotic bottoms, between 109 and $152 \mathrm{~m}$ deep, generally associated with rhodolith beds, or areas with dead rhodoliths on the summits of EB and AM, but also sporadically at the same depths on trawl fishing grounds of the continental shelf of Mallorca.

PeerJ reviewing PDF | (2021:04:59975:2:0:NEW 2 Jul 2021) 


\section{Remarks}

1029 This is the third record of the species and the third for the Mediterranean, where it was only 1030 known from the Alboran Sea (Sitjà \& Maldonado, 2014). It is also the third report worldwide, 1031 considering the type locality at Cabo Verde in the eastern Atlantic (Topsent, 1928).

1032 Class HEXACTINELLIDA Schmidt, 1870

1033 Subclass HEXASTEROPHORA Schulze, 1886

1034 Order LYSSACINOSIDA Zittel, 1877

1035 Family ROSSELLIDAE Schulze, 1885

1036 Subfamily LANUGINELLIDAE Gray, 1872

1037 Genus Lanuginella Schmidt, 1870

1038 Lanuginella pupa Schmidt, 1870

1039 (Fig. 19; Table 11)

Material examined

CFM-IEOMA-7412/i286_1, CFM-IEOMA-7413/i286_2 and CFM-IEOMA-7414/i286_3, St 18, 1042 AM, RD.

Description

1044

1045

1046

1047

1048

1049

1050

1051

1052

1053

1054

1055

1056

1057

1058

1059

1060

Tubular (CFM-IEOMA-7412/i286_1) to calyx-like (CFM-IEOMA-7413/i286_2 and CFMIEOMA-7414/i286_3) sponges (Fig. 19A), up to $4 \mathrm{~cm}$ high and $2 \mathrm{~cm}$ in diameter. Surface smooth, but slightly hispid at localized areas. Fragile consistency and soft touch. Dirty white color in life and white after preservation in EtOH. All the three specimens present a single, circular oscule at the upper part of the body. One of the calyx-like specimens (CFM-IEOMA$\mathrm{XXX/i286 \_ 2)} \mathrm{has} \mathrm{a} \mathrm{minute} \mathrm{and} \mathrm{short} \mathrm{peduncle.}$

\section{Skeleton}

As usual for the species (see Ijima, 1904; Tabachnick, 2002 and Sitjà et al., 2019 for detailed descriptions)

\section{Spicules}

Choanosomal diactines (Fig. 19B): long and slim, slightly sinuous, with four vestigial tubercles in the center (Fig. 19B1), which may have swelings all over the shaft and spines on their tips. They measure $245-1611 \times 3-15 \mu \mathrm{m}$.

Choanosomal hexactines (Fig. 19C): with actines of different lengths, sometimes sinuous. They measure 349-983 x 10-25 $\mu \mathrm{m}(\mathrm{n}=12)$.

Hypodermal pentactines (Fig. 19D): with a ray reduced to a stump or absent. Proximal ray much larger than the others and perpendicularly arranded. Rays are smooth or slightly rugose.

Peer] reviewing PDF | (2021:04:59975:2:0:NEW 2 Jul 2021) 
1061 Proximal ray measuring 242-950 x 7-19 $\mu \mathrm{m}(\mathrm{n}=8)$ and perpendicular rays measuring 137-850 x $1062 \quad 4-20 \mu \mathrm{m}(\mathrm{n}=28)$.

1063 Stauractines (Fig. 19E): with four actines perpendicularly arranged one another in the same 1064 plane. They are straight or slightly curved, strongly spined, with roundish tips. They measure 61$1065111 \times 3-5 \mu \mathrm{m}(\mathrm{n}=23)$.

1066 Dermal hexactines (not shown): uncommon. Rugose, with the proximal ray slightly longer than 1067 the distal one. Overall measures: proximal rays $151 \times 7 \mu \mathrm{m}(\mathrm{n}=1)$, distal rays $105 \times 6 \mu \mathrm{m}(\mathrm{n}=1)$ 1068 and perpendicular rays $68-110 \times 2-6 \mu \mathrm{m}(\mathrm{n}=3)$.

1069 Paratetractin: only a single spicule observed, measuring77/4 $(n=1)$.

1070 Atrialia hexactines (Fig. 19F and 19G): common. Slightly rough to smooth. Overall measures: 1071 proximal rays 107-159 x 4-6 $\mu \mathrm{m}(\mathrm{n}=8)$, distal rays $70-102 \times 4-7 \mu \mathrm{m}(\mathrm{n}=8)$ and perpendicular 1072 rays $70-150 \times 3-7 \mu \mathrm{m}(\mathrm{n}=22)$.

1073 Discohexasters (Fig. 19H): rather uncommon. Some with underdeveloped, twisted rays. They 1074 measure 43-76 $\mu \mathrm{m}(\mathrm{n}=29)$.

1075 Strobiloplumicomes (Fig. 19I): very rare and not found in specimen CFM-IEOMA-7413/i286_2. 1076 They measure: $20-38 \mu \mathrm{m}(\mathrm{n}=6)$.

\section{Ecological notes}

1078

1079

1080

1081

1082

1083

1084

1085

1086

1087

1088

1089

1090

1091

1092

1093

1094

1095

1096

Species found only at one station located in a rocky slope at SO, between 220 and $275 \mathrm{~m}$ deep. It was associated with fossil ostreid reefs and carbonated rocks, together with other encrusting sponges like Hamacantha sp., Bubaris sp., and Jaspis sp.

\section{Remarks}

This poorly-known species is the single representative of the genus Lanuginella, reported at several distant locations around the world: Kagoshima Gulf at the Sea of China (Okada, 1932), $\mathrm{Ki}$ Island at the Sea of Banda (Schulze, 1887). In the northern Atlantic it was recorded at Cabo Verde (Schmidt, 1870), the Gulf of Cadiz (Sitjà et al., 2019) and the Strait of Gibraltar (Topsent, 1895). This is the first record of the species in the Mediterranean Sea, increasing its already wide distribution. However, a revision of the species is needed, and it is likely that such a cosmopolitan distribution may indicate that L. pupa represents a species complex. However, deep-sea species tend to be more widely distributed than shallow ones, probably because of the uniformity of in the environmental conditions (McClain \& Hardy, 2010). A detailed examination of worldwide specimens, combined with molecular methods, may shed more light on it.

\section{Discussion}

\section{Biogeography and seamount singularity}

The present study increases the knowledge of the sponge diversity of the Mediterranean seamounts. We describe a new genus, 4 new species, and 15 new geographical reports, including two new reports for the Mediterranean Sea. This study also highlights Foraminospongia 
1097 balearica sp. nov. as one of the most common sponges at AM and EB, being large and easily

1098

1099

1100

1101

1102

1103

1104

1105

1106

1107

1108

1109

1110

1111

1112

1113

1114

1115

1116

1117

1118

1119

1120

1121

1122

1123

1124

1125

1126

1127

1128

1129

1130

1131

1132

1133

1134

1135

1136

1137

1138

distinguishable. This species was never recorded at other previously explored Mediterranean seamounts or ridges of a similar depth range, such as the Seco de los Olivos or the Alboran Ridge, whose sponge fauna has been already studied (Sitjà \& Maldonado, 2014; Würtz \& Rovere, 2015; De la Torriente et al., 2018). Therefore, the Mallorca Channel seamounts may be considered unique faunal refuges, appealing to what is called the "Seamount endemism hypothesis" (de Forges et al., 2000), which suggests that geographical separation of seamounts is reflected by genetic isolation of their fauna, which promotes speciation by vicariance. This hypothesis has been questioned, as some works have shown that benthic fauna (including sponges) is well connected among isolated seamounts (Samadi et al., 2006; Ekins et al., 2016). However, others have shown structured populations between seamounts (Castelin et al., 2010), or between seamounts and the continental shore populations (Crochelet, 2020). Other authors suggest that there is a mixture of panmictic and structured populations, largely dependent on the characteristics of the single species nature (Rogers, 2018). If we consider that the dispersal of sponges tend to be very limited (Maldonado, 2006; Riesgo et al., 2019; Shaffer et al., 2020; Griffiths et al., 2021), it is plausible that certain seamount sponge populations are highly structured. This limitation in the dispersal may be enhanced in isolated seamounts or in those with peculiar or unique ecological characteristics. In this sense, both AM and EB have very shallow summits and are placed in an area of special oligotrophy (e.g. Bosc et al., 2004; Uitz et al., 2012). The nearest habitat with similar features is the continental shelf of the Balearic promontory, although these areas tend to be under the impact of bottom-trawling (Farriols et al. 2017; Ordines et al., 2017), with the consequent impoverishment of benthic communities (Jennings \& Kaiser, 1998). In fact, most of the species of SO, AM and the EB had not been found at the continental shelf of the Balearic Islands (Bibiloni, 1990; 1993; Grinyo et al., 2018; Santin et al., 2018), except for Phakellia robusta, P. hirondellei (Santin et al., 2018), Petrosia (Petrosia) raphida, and Hemiasterella elongata (this work).

The particular conditions of the Balearic Islands, extreme oligotrophy, geographical isolation, low fishing pressure and heterogeneity of habitats (Quetglas et al., 2012; Massutí et al., 2014) suggest this area is a hotspot of sponge diversity, with much of its fauna still unknown, especially at depth below 90 m (Bibiloni, 1990; Santin et al., 2018; Díaz et al., 2020). In recent years, this high diversity has been evidenced by the presence of rich benthic assemblages (Ordines \& Massutí, 2009; Barberá et al., 2012; Ordines et al., 2017), as well as by a high number of new species and new geographical reports (e.g. Kovačić et al., 2017, 2019; Ordines et al., 2019; Díaz et al., 2020). Thus, there is a need to find out which sponge species inhabit those waters and how much do they contribute to the benthic biomass. Sponges are key components of the benthic ecosystems, playing important biogeochemical roles (de Goeij et al., 2013) and serving as food or refugee to many other animals (Maldonado et al., 2017). Future works should characterize those benthic habitats of the continental shelf and slope around the Balearic Islands that are potentially similar to those of the Mallorca Channel seamounts (e.g. non-impacted sedimentary and rocky bottoms with rhodoliths and gravels located between 90 and $150 \mathrm{~m}$ deep and rocky slopes down to 400-500 $\mathrm{m}$ deep). Then, both biocenosis should be compared to confirm the singularity of the habitats of the Mallorca Channel seamounts.

Peer] reviewing PDF | (2021:04:59975:2:0:NEW 2 Jul 2021) 
1139

1140

1141

1142

1143

1144

1145

1146

1147

1148

1149

1150

1151

1152

1153

1154

1155

1156

1157

1158

1159

1160

1161

1162

1163

1164

1165

1166

1167

1168

1169

1170

1171

1172

1173

1174

1175

1176

1177

\section{Acknowledgements}

The generalized lack of distinctive characters has caused sponges to be one of the most difficult groups to classify. This difficulty is also reflected by sponge phylogenetic relationships, with polyphyletic taxa present in all the levels of the Linnean classification (e.g. Cardenas, 2012; Diaz et al., 2020). Thus, the use of both morphology and molecular markers is central to the improvement of the knowledge of this group of organisms. Following this approach, here we have proposed the new genus Foraminospongia to be erected in the family Hymerhabdiidae, supported by the two new species Foraminospongia balearica sp. nov. and Foraminospongia minuta sp. nov., confirmed by morphological traits and both COI and $28 \mathrm{~S}$ markers. On the other hand, the species Heteroxya cf. beauforti has shown no variability in its COI sequence relative to its North Atlantic congenerics, which highlights the importance of morphology and the need to combine both approaches. The COI is known to be a low-resolution marker to discriminate species of sponges, so we also sequenced the more variable $28 \mathrm{~S}$ marker. However, no $28 \mathrm{~S}$ sequences are currently available in any database for comparison with the other Heteroxya spp.: this issue should thus be adressed in the future.

A key subject in sponge taxonomy is the robustness of the skeletal characters as a species diagnostic tool, and how reliable they are for discriminating species and populations. Reliable discrimination is further complicated by the fact that skeletal elements may change depending on environmental conditions such as temperature, depth, or nutrient concentration; skeletal elements may also change due to intraspecific plasticity, overall modifying length, width, morphology, and even their presence or absence (Cárdenas et al., 2012; Abdul Wahab et al., 2020). No consensus has ever been reached to consider a given morphological deviation as enough evidence to erect a new species, a fact that remains arbitrary. We have found differences in the spicular morphometry between the specimens of the Balearic Islands and specimens of other areas of the Mediterranean and the North Atlantic Ocean; these differences have been described here for most of the species to some extent. Since the dispersive potential, long-distance connectivity, and speciation of sponges are poorly understood, most of the diagnosis in the present work were performed under a conservative approach, only proposing new species when we found solid morphological evidence. Taking this into account, factors like vast geographical distances, presence of oceanographic barriers or minor morphometric differences were not considered enough evidence for species delimitation. In the case of Calyx cf. tufa, its potential conspecificity with the North Atlantic species $C$. tufa cannot be discarted. We did not get access to any material of $C$. tufa, and no sequences are available for comparison; moreover, the original description is too vague and general. However, as stated above, the absence of any intermediate records of such a big, conspicuous, and easily recognizable sponge is noreworthy. Also, the recorded depths of $C$. tufa for the Atlantic are much deeper than those for C. cf. tufa (219 and $300 \mathrm{~m}$ versus $105-114 \mathrm{~m}$ ). Future work is need to clarify if both species are synonyms, or if $C$. cf. tufa is a new species for science. 
1179 The authors wish to thank the captain and crew of R/Vs Ángeles Alvariño, Sarmiento de Gamboa 1180 and Miguel Oliver, as well as the participants in the INTEMARES surveys at the Mallorca 1181 Channel seamounts and the MEDITS 2017, 2019 and 2020 surveys. Special thanks to Dr. Ferran 1182 Hierro (University of the Balearic Islands) for the technical assistance at the scanning electron 1183 microscope, to Dr. Paco Cárdenas, for taxonomic advice, to Maria Teresa Farriols and Helena 1184 Marco for the logistic work during the development of the INTEMARES surveys. Lastly, we 1185 would like to thank Professor Maurizio Pansini and the two anonymous reviewers for their 1186 constructive comments and corrections to the original manuscript.

\section{References}

1189

1190

1191

1192

1193

1194

1195

1196

1197

1198

1199

1200

1201

1202

1203

1204

1205

1206

1207

1208

1209

1210

1211

1212

1213

1214

Acosta J., Ancochea E., Canals M., Huertas M. J. \& Uchupi E. 2004. Early Pleistocene volcanism in the Emile Baudot Seamount, Balearic Promontory western Mediterranean Sea. Marine Geology, 207, 247-257.

Aguilar R., López -Correa M., Calcinai B., Pastor X., de la Torriente A. \& García S. 2011. First records of Asbestopluma hypogea Vacelet and Boury-Esnault, 1996 Porifera, Demospongiae Cladorhizidae on seamounts and in bathyal settings of the Mediterranean Sea. Zootaxa, 2925, 3340 .

Altschul S. F., Gish W., Miller W., Myers E. W. \& Lipman D. J. 1990. Basic local alignment search tool. Journal of Molecular Biology, 215, 403-410.

Alvarez B., Hooper J. N. A. 2002. Family Axinellidae Carter, 1875. Pp. 724-747. In Hooper, J.N.A. \& Van Soest, R.W.M. ed. Systema Porifera. A guide to the classification of sponges. 1 Kluwer Academic/ Plenum Publishers: New York, Boston, Dordrecht, London, Moscow.

Bertolino M., Cerrano C., Bavestrello G., Carella M., Pansini M., Calcinai B. 2013. Diversity of Porifera in the Mediterranean coralligenous accretions, with description of a new species. ZooKeys, 336: 1-37.

Bertolino M., Bo M., Canese S., Bavestrello G. \& Pansini M. 2015. Deep sponge communities of the Gulf of St Eufemia Calabria, southern Tyrrhenian Sea, with description of two new species. Marine Biological Association of the United Kingdom. Journal of the Marine Biological Association of the United Kingdom, 957, 1371.

Bertrand J. A., de Sola L. G., Papaconstantinou C., Relini G. \& Souplet A. 2002. The general specifications of the MEDITS surveys. Scientia Marina, 66, 9-17.

Bibiloni M. A. 1990. Fauna de Esponjas de las Islas Baleares. Variación cualitativa y cuantitativa de la población de esponjas en un gradiente batimétrico. Comparación Baleares-Costa Catalana. PhD Thesis. Universitat de Barcelona, Barcelona, Spain.

Bibiloni M. A. 1993. Some new or poorly known sponges of the Balearic Islands western Mediterranean. Scientia Marina, 574, 307-318.

PeerJ reviewing PDF | (2021:04:59975:2:0:NEW 2 Jul 2021) 
1215 Bo M., Bertolino M., Borghini M., Castellano M., Harriague A. C., Di Camillo C. G., Gasparini 1216 G., Gasparini C., Paolo M., Povero P., Pusceddu A., Schroeder K. \& Bavestrello G. 2011.

1217 Characteristics of the mesophotic megabenthic assemblages of the Vercelli seamount North

1218 Tyrrhenian Sea. PLoS One, 62, e16357.

1219 Bo M., Coppari M., Betti F., Enrichetti F., Bertolino M., Massa F., Bava S., Gay G., 1220 Cattaneo-Vietti R. \& Bavestrello G. 2020. The high biodiversity and vulnerability of two 1221 Mediterranean bathyal seamounts support the need for creating offshore protected areas. Aquatic 1222 Conservation: Marine and Freshwater Ecosystems, 1-24.

1223 Bosc E., Bricaud A. \& Antoine D. 2004. Seasonal and interannual variability in algal biomass and primary production in the Mediterranean Sea, as derived from 4 years of SeaWiFS observations. Global Biogeochem. Cycles. 18, GB1005.

Boury-Esnault N., Pansini M. \& Uriz M. J. 1994. Spongiaires bathyaux de la mer d'Alboran et du golfe ibéro-marocain. Mémoires du Muséum national d'Histoire naturelle. 160.

Boury-Esnault N. \& Rützler K. 1997. Thesaurus of sponge morphology. Smithsonian contributions to zoology, 596, 1-55.

Bowerbank J.S. 1866. A Monograph of the British Spongiadae. Volume 2. Ray Society: London: i-xx, 1-388.

1232

1233

1234

1235

1236

1237

1238

1239

1240

1241

1242

1243

1244

1245

1246

1247

1248

1249

1250
Calcinai B., Moratti V., Martinelli M., Bavestrello G. \& Taviani M. 2013. Uncommon sponges associated with deep coral bank and maerl habitats in the Strait of Sicily Mediterranean Sea. Italian Journal of Zoology, 80, 412-423.

Castelin M., Lambourdiere J., Boisselier M. C., Lozouet P., Couloux A., Cruaud C. \& Samadi S. 2010. Hidden diversity and endemism on seamounts: focus on poorly dispersive neogastropods. Biological Journal of the Linnean Society, 1002, 420-438.

Cárdenas P., Perez T. \& Boury-Esnault N. 2012. Sponge systematics facing new challenges. In Advances in marine biology Vol. 61, pp. 79-209. Academic Press.

Cedro V. R., Hajdu E. \& Correia M. D. 2013. Three new intertidal sponges Porifera: Demospongiae from Brazil's fringing urban reefs Maceió, Alagoas, Brazil, and support for Rhabderemia's exclusion from Poecilosclerida. Journal of Natural History, 4733-34, 2151-2174.

Chombard C., Boury-Esnault N. \& Tillier S. 1998. Reassessment of homology of morphological characters in Tetractinellid sponges based on molecular data. Systematic Biology, 47, 351-366.

Clark M. R., Schlacher T. A., Rowden A. A., Stocks K. I. \& Consalvey M. 2012. Science priorities for seamounts: research links to conservation and management. PloS one, 71, e29232.

Corbera G., Iacono C. L., Gràcia E., Grinyó J., Pierdomenico M., Huvenne V. A., Aguilar R. \& Gili J. M. 2019. Ecological characterisation of a Mediterranean cold-water coral reef: Cabliers Coral Mound Province Alboran Sea, western Mediterranean. Progress in Oceanography, 175, 245-262. 
1251 Costa G., Bavestrello G., Micaroni V., Pansini M., Strano F. \& Bertolino M. 2019. Sponge 1252 community variation along the Apulian coasts Otranto Strait over a pluri-decennial time span. 1253 Does water warming drive a sponge diversity increasing in the Mediterranean Sea?. Journal of 1254 the Marine Biological Association of the United Kingdom, 99 7, 1519-1534.

1255 Crochelet E., Barrier N., Andrello M., Marsac F., Spadone A. \& Lett C. 2020. Connectivity 1256 between seamounts and coastal ecosystems in the Southwestern Indian Ocean. Deep Sea 1257 Research Part II: Topical Studies in Oceanography, 104774.

1258 de Forges B. R., Koslow J. A. \& Poore G. C. B. 2000. Diversity and endemism of the benthic 1259 seamount fauna in the southwest Pacific. Nature, 4056789, 944-947.

1260 Danovaro R., Fanelli E., Canals M., Ciuffardi T., Fabri M. C., Taviani M., Argyrou M., Azurro 1261 E., Bianchelli S., Cantafaro A., Carugati L., Corinaldesi C., P De Haan W., Dell'Anno A., Evans 1262 J., Foglini F., Galil B., Gianni M., Goren M., Greco S., Grimalt J., Güell-Bujons Q., Jadaud A., 1263 Knittweis L., Lopez JL., Sanchez-Vidal A., Schembri P. J., Snelgrove P., Vaz S., Angeletti L., 1264 Barsanti M., Borg JA., Bosso M., Brind'Amour A., Castellan G., Conte F., Delbono I., Galgani 1265 F., Morgana G., Prato S., Schirone A., Soldevilla E. 2020. Towards a marine strategy for the 1266 deep Mediterranean Sea: Analysis of current ecological status. Marine Policy, 112, 103781.

1267 De Goeij J. M., Van Oevelen D., Vermeij M. J., Osinga R., Middelburg J. J., De Goeij A. F. \& 1268 Admiraal W. 2013. Surviving in a marine desert: the sponge loop retains resources within coral 1269 reefs. Science, 3426154, 108-110.

De la Torriente A., Serrano A., Fernández-Salas L. M., García M. \& Aguilar R. 2018. Identifying epibenthic habitats on the Seco de los Olivos Seamount: Species assemblages and environmental characteristics. Deep Sea Research Part I: Oceanographic Research Papers, 135, 9-22.

Díaz J., Ramírez-Amaro S., Ordines F., Cárdenas P., Ferriol P., Terrasa B. \& Massutí E. 2020. Poorly known sponges in the Mediterranean with the detection of some taxonomic inconsistencies. Journal of the Marine Biological Association of the United Kingdom, 1-14.

D'Onghia G., Capezzuto F., Cardone F., Carlucci R., Carluccio A., Chimienti G., Corriero G., Longo C., Maiorano P., Mastrototaro F., Panetta P., Rosso A., Sanfilippo R., Sion L. \& Tursi A. 2015. Macro- and megafauna recorded in the submarine Bari Canyon southern Adriatic, Mediterranean Sea using different tools. Mediterranean Marine Science. 161, 180-196.

Enrichetti F., Bavestrello G., Betti F., Coppari M., Toma M., Pronzato R., Canese S., Bertolino M., Costa G., Pansini M. \& Bo M. 2020. Keratose-dominated sponge grounds from temperate mesophotic ecosystems (NW Mediterranean Sea). Marine Ecology, e12620.

Estrada M 1996 Primary production in the northwestern Mediterranean. Scientia Marina, 60: Supp1. 355-64.

Ekins M., Erpenbeck D., Wörheide G. \& Hooper J. N. 2016. Staying well connected-Lithistid sponges on seamounts. Journal of the Marine Biological Association of the United Kingdom, 2, 437-451. 
1289 Evcen A. \& Çinar M. E. 2012. Sponge Porifera species from the Mediterranean coast of Turkey 1290 Levantine Sea, eastern Mediterranean, with a checklist of sponges from the coasts of Turkey. 1291 Turkish Journal of Zoology, 36, 460-464.

1292 Farriols M. T., Ordines F., Somerfield P.J., Pasqual C., Hidalgo M., Guijarro B. \& Massutí E. 1293 2017. Bottom trawl impacts on Mediterranean demersal fish diversity: Not so obvious or are we 1294 too late?. Continental Shelf Research.

1295 Ferrer Hernández F. 1914. Esponjas del Cantábrico. Parte 2. III. Myxospongida. IV. Tetraxonida. 1296 V. Triaxonida. Trabajos del Museo Nacional de Ciencias Naturales Zoológica, 17, 1-46.

1297 Fiorentini L., Dremière P-Y., Leonori I., Sala A. \& Palumbo V. 1999. Efficiency of the bottom 1298 trawl used for the Mediterranean international trawl survey MEDITS. Aquatic Living Resources, 1299 12, 187-205.

1300 Folmer O., Black M., HoehW., Lutz R. \& Vrijenhoek R. 1994. DNA Primers for amplification of mitochondrial cytochrome c oxidase subunit I from diverse metazoan invertebrates. Molecular Marine Biology and Biotechnology, 3, 294-299.

Fourt M., Goujard A., Pérez T., Chevaldonné P. 2017. Guide de la faune profonde de la mer Méditerranée. Explorations des roches et des canyons sous-marins des côtes françaises. Patrimoines naturels. Publications scientifiques du Museum national d'Histoire naturelle Paris, 75, 1-184.

Galil B. \& Zibrowius H. 1998. First benthos samples from Eratosthenes Seamount, eastern Mediterranean. Senckenbergiana maritima, 284-6, 111.

Gerovasileiou V. \& Voultsiadou E. 2012. Marine Caves of the Mediterranean Sea: A Sponge Biodiversity Reservoir within a Biodiversity Hotspot. PLoS ONE, 77, e39873. features and limited dispersal shape the population genetic structure of the vase sponge Ircinia campana in the Greater Caribbean. Heredity 126, 63-76.

Grinyó J., Gori A., Greenacre M., Requena S., Canepa A., Iacono C. L., ... \& Gili J. M. 2018. Megabenthic assemblages in the continental shelf edge and upper slope of the Menorca Channel, Western Mediterranean Sea. Progress in Oceanography, 162, 40-51. stress induction by the invasive sponge Paraleucilla magna growing on Peyssonnelia squamaria algae. Marine Environmental Research, 150, 104763.

Hall T. 1999. Bioedit: a user-friendly biological sequence alignment editor and analysis program for Windows 95/98/NT. Nucleic Acids Symposium Series, 41, 95-98.Hentschel E. 1929. Die Kiesel- und Hornschwämme des Nördlichen Eismeers. Pp. 857-1042, pls XII-XIV. In: Römer, F., Schaudinn, F., Brauer, A. \& Arndt, W. Eds, Fauna Arctica. Eine Zusammenstellung der arktischen Tierformen mit besonderer Berücksichtigung des Spitzbergen-Gebietes auf Grund der 
1325 Ergebnisse der Deutschen Expedition in das Nördliche Eismeer im Jahre 1898, 54 G.Fischer, 1326 Jena

1327 Hooper J. N. A. 2003 Sponguide. Guide to sponge collection and identification version 2003

1328 John N. A. Hooper Qld. Museum, Australia.

1329 Hooper J. N. A. \& Van Soest R. W. 2002. Systema Porifera. A guide to the classification of 1330 sponges. Kluwer Academic/Plenum Publishers, New York.

1331 Jennings S., \& Kaiser M. J. 1998. The effects of fishing on marine ecosystems. Advances in 1332 marine biology, 34, 201-352.

1333 Katoh K., Misawa K., Kuma K. \& Miyata T. 2002. MAFFT: a novel method for rapid multiple 1334 sequence alignment based on fast Fourier transform. Nucleic Acids Research 30, 3059-3066.

1335 Kovačić M., Ordines F. \& Schliewen U. K 2017 A new species of Buenia Teleostei: Gobiidae 1336 from the western Mediterranean Sea, with the description of this genus. Zootaxa, 4250, 447-460.

1337 Lambe L. M. 1900. Sponges from the coasts of north-eastern Canada and Greenland.

1338 Transactions of the royal Society of Canada, 6, 19-49.

1339 Longo C., Cardone F., Pierri C., Mercurio M., Mucciolo S., Marzano C. N., Corriero G. 2018. 1340 Sponges associated with coralligenous formations along the Apulian coasts. Marine Biodiversity, $1341484,2151-2163$.

1342 Lundbeck, W. 1905. Porifera. Part II. Desmacidonidae. The Danish Ingolf-Expedition. 62:1-219

1343 Lundbeck W. 1909. The Porifera of East Greenland. Meddelelser om Grønland, 29: 423-464.

1344 McClain, C. R. \& Hardy S. M. 2010. The dynamics of biogeographic ranges in the deep sea.

1345 Proceedings of the Royal Society B: Biological Sciences, 2771700, 3533-3546.

1346 Maldonado M. 1992. Demosponges of the red coral bottoms from the Alboran Sea. Journal of 1347 Natural History, 26, 1131-1161.

1348 Maldonado M. 2006. The ecology of the sponge larva. Canadian Journal of Zoology, 842, 1751349194.

1350 Maldonado M., Carmona M. C., Uriz M. J. \& Cruzado A. 1999. Decline in Mesozoic reef1351 building sponges explained by silicon limitation. Nature, 401, 785-788 1999.

1352 Maldonado M., Aguilar R., Blanco J., Garcia S., Serrano A. \& Punzon A. 2015. Aggregated 1353 clumps of lithistid sponges: a singular, reef-like bathyal habitat with relevant paleontological 1354 connections. PLoS One, 105, e0125378.

1355 Maldonado M., Aguilar R., Bannister R. J., Bell J.J., Conway K.W., Dayton P.K., Díaz C., Gutt 1356 J., Kelly M., Kenchington E. L. R., Leys S. P., Pomponi S. A., Rapp H. T., Rützler K., Tendal O. 1357 S., Vacelet J., Young C. M. 2016. Sponge grounds as key marine habitats: a synthetic review of 1358 types, structure, functional roles, and conservation concerns. In: Rossi S, editor. Marine animal 1359 forests. Switzerland: Springer International Publishing. p. 1-39. 
1360 Manconi R., Padiglia A., Cubeddu T. \& Pronzato R. 2019. Long-term sponge stranding along the

1361

1362

1363

1364

1365

1366

1367

1368

1369

1370

1371

1372

1373

1374

1375

1376

1377

1378

1379

1380

1381

1382

1383

1384

1385

1386

1387

1388

1389

1390

1391

1392

1393

1394

shores of Sardinia Island (Western Mediterranean Sea). Marine Ecology, 40(6), e12567.

Massutí E., Olivar M. P., Monserrat S., Rueda L. \& Oliver P. 2014. Towards understanding the influence of environmental conditions on demersal resources and ecosystems in the western Mediterranean: Motivations, aims and methods of the IDEADOS project. Journal of Marine Systems, 138, 3-19.

Miller M.A., Pfeiffer W. \& Schwartz T. 2010. Creating the CIPRES Science Gateway for inference of large phylogenetic trees. Proceedings of the Gateway Computing Environments Workshop GCE, pp. 1-8.

Mioso R., Marante F. J. T., Bezerra R. D. S., Borges, F. V. P., Santos, B. V., \& Laguna, I. H. B. D. 2017. Cytotoxic compounds derived from marine sponges. A review 2010-2012. Molecules, $222,208$.

Monserrat S., López-Jurado J. L. \& Marcos M. 2008. A mesoscale index to describe the regional circulation around the Balearic Islands. Journal of Marine Systems, 713-4, 413-420.

Morato T., Kvile K. Ø., Taranto G. H., Tempera F., Narayanaswamy B. E., Hebbeln D., Menezes G. M., Wienberg C., Santos R. S. \& Pitcher, T. J. 2013. Seamount physiography and biology in the north-east Atlantic and Mediterranean Sea. Biogeosciences, 105, 3039.

Morrow C., Cárdenas P., Boury-Esnault N., Picton B., McCormack G., Van Soest R., Collins A., Redmond N., Maggs C., Sigwart J. \& Allcock L.A. 2019. Integrating morphological and molecular taxonomy with the revised concept of Stelligeridae Porifera: Demospongiae. Zoological Journal of the Linnean Society.

OCEANA 2011. Montañas submarinas de las Islas Baleares: Canal de Mallorca. Propuesta de protección para Ausias March, Emile Baudot y Ses Olives. OCEANA, 64 pp.

Ordines F. \& Massutí E. 2009. Relationships between macro-epibenthic communities and fish on the shelf grounds of the western Mediterranean. Aquatic Conservation: Marine and freshwater ecosystems, 194, 370-383.

Ordines F., Jordà G., Quetglas A., Flexas M., Moranta J. \& Massutí E. 2011. Connections between hydrodynamics, benthic landscape and associated fauna in the Balearic Islands, western Mediterranean. Cont. Shelf Res. 31 17, 1835-1844.

Ordines F., Ramírez-Amaro S., Fernandez-Arcaya U., Marco-Herrero E. \& Massutí E. 2019. First occurrence of an Ophiohelidae species in the Mediterranean: the high abundances of Ophiomyces grandis from the Mallorca Channel seamounts. Journal of the Marine Biological Association of the United Kingdom, 998, 1817-1823.

Pansini M. 1984. Notes on some Mediterranean Axinella with description of two new species. Bollettino dei Musei e degli Istituti Biologici dell'Universitá di Genova. 50-51, 79-98

PeerJ reviewing PDF | (2021:04:59975:2:0:NEW 2 Jul 2021) 
1395 Pansini M., Manconi R. \& Pronzato R. 2011. Porifera I. Calcarea, Demospongiae (partim), 1396 Hexactinellida, Homoscleromorpha. Fauna d'Italia, Vol. 46. Bologna: Calderini-Il Sole 24 Ore. 1397554 pp. ISBN: 978-88-506-5395-9

1398

1399

1400

1401

1402

1403

1404

1405

1406

1407

1408

1409

1410

1411

1412

1413

1414

1415

1416

1417

1418

1419

1420

1421

1422

1423

1424

1425

1426

1427

1428

1429

1430

Pardo E., Rubio R. A., García S. \& Ubero J. 2011. Documentación de arrecifes de corales de agua fría en el Mediterráneo occidental Mar de Alborán. Chronica naturae, 1, 20-34.

Pinot J. M., López-Jurado J. L. \& Riera M. 2002. The CANALES experiment 1996-1998. Interannual, seasonal, and mesoscale variability of the circulation in the Balearic Channels. Progress in Oceanography, 553-4, 335-370.

Plotkin A., Gerasimova E. \& Rapp H. T. 2011. Phylogenetic reconstruction of Polymastiidae Demospongiae: Hadromerida based on morphology. In Ancient Animals, New Challenges pp. 21-41. Springer, Dordrecht.

Pulitzer-Finali G. 1978. Report on a collection of sponges from the bay of Naples. III Hadromerida, Axinellida, Poecilosclerida, Halichondrida, Haplosclerida. Bollettino dei Musei e degli Istituti Biologici dell'Universitá di Genova, 45, 7-89.

Pulitzer-Finali G. 1983. A collection of Mediterranean Demospongiae Porifera with, in appendix, a list of the Demospongiae hitherto recorded from the Mediterranean Sea. Annali del Museo civico di storia naturale Giacomo Doria, 84, 445-621.

Reiss H., Kröncke I. \& Ehrich S. 2006. Estimating the catching efficiency of a 2-m beam trawl for sampling epifauna by removal experiments. ICES Journal of Marine Science, 63, 1453-1464

Rützler K. 1990. Association between Caribbean sponges and photosynthetic organisms. In New Perspective in Sponge Biology: 3d International Sponge Conference, 1985. Smithsonian Institution Press.

Ridley S.O. \& Dendy A. 1886. Preliminary report on the Monaxonida collected by H.M.S. Challenger. Part I. Annals and Magazine of Natural History. 18, 325-351, 470-493.

Riesgo A., Taboada S., Pérez-Portela R., Melis P., Xavier J. R., Blasco G. \& López-Legentil S. 2019. Genetic diversity, connectivity and gene flow along the distribution of the emblematic Atlanto-Mediterranean sponge Petrosia ficiformis Haplosclerida, Demospongiae. BMC evolutionary biology, 191, 24.

Rogers A. D. 2018. The biology of seamounts: 25 Years on. In Advances in marine biology Vol. 79, pp. 137-224. Academic Press.

Ronquist F., Teslenko M., Van Der Mark P., Ayres D.L., Darling A., Höhna S., Larget B., Liu L., Suchard M.A. \& Huelsenbeck J.P. 2012. MrBayes 3.2: efficient Bayesian phylogenetic inference and model choice across a large model space. Systematic biology 61(3), 539-542.

Samadi S., Bottan L., Macpherson E., De Forges B.R. \& Boisselier M-C. 2006. Seamount endemism questioned by the geographic distribution and population genetic structure of marine invertebrates. Marine Biology 1496,1463-1475 
1431 Samadi S., Schlacher T. \& Richer de Forges B. 2007. Seamount benthos. In: Seamounts:

1432 Ecology, Fisheries and Conservation. Blackwell, 119-140.

1433 Santinelli C. 2015. DOC in the Mediterranean Sea. In Biogeochemistry of marine dissolved 1434 organic matter pp. 579-608. Academic Press.

Sarà M. 1958a. Contributo all consoscenza dei Poriferi del Mar Ligure. Annali di Museo Civico di Storia Naturale Genova, 70, 207-244.

Sarà M. 1958b. Studio sui Poriferi di una grotta di marea del Golfo di Napoli. Archivo Zoologico Italiano, 43, 203-281

Schindelin J., Arganda-Carreras I., Frise E., Kaynig V., Longair M., Pietzsch T., Preibisch S., Rueden C., Saalfeld S., Schmid B., Tinevez J-Y., White D.J., Hartenstein V., Eliceiri K.,

1442 Tomancak P. \& Cardona A. 2012. Fiji: An open-source platform for biological image analysis. 1443 Nature Methods 9, 676-682.

1444 Schmidt, O. 1870. Grundzüge einer Spongien-Fauna des atlantischen Gebietes. Wilhelm 1445 Engelmann: Leipzig: iii-iv, 1-88, pls I-VI.

1446 Schmidt, O. 1875. Spongien. Die Expedition zur physikalisch-chemischen und biologischen 1447 Untersuchung der Nordsee im Sommer 1872. Jahresbericht der Commission zur 1448 Wissenschaftlichen Untersuchung der Deutschen Meere in Kiel. 2-3: 115-120

1449

1450

1451

1452

1453

1454

1455

1456

1457

1458

1459

1460

1461

1462

1463

1464

1465

1466
Shaffer M. R., Luter H. M., Webster N. S., Wahab M. A. A. \& Bell J. J. 2020. Evidence for genetic structuring and limited dispersal ability in the Great Barrier Reef sponge Carteriospongia foliascens. Coral Reefs 39, 39-46.

Simpson T. L. 1978. The biology of the marine sponge Microciona prolifera Ellis and Sollander. III. Spicule secretion and the effect of temperature on spicule size. Journal of Experimental Marine Biology and Ecology 35, 31-42.

Sitjà C. \& Maldonado M. 2014. New and rare sponges from the deep shelf of the Alboran Island Alboran Sea, Western Mediterranean. Zootaxa 3760, 141-179.

Sitjà C., Maldonado M., Farias C. \& Rueda J.L. 2019. Deep-water sponge fauna from the mud volcanoes of the Gulf of Cadiz North Atlantic, Spain. Journal of the Marine Biological Association of the United Kingdom 99, 807-831.

Solórzano, M.R. 1990. Poríferos del litoral gallego: estudio faunístico, distribución e inventario. Phd Thesis Unversidad de Santiago de Compostela. 1036 pp.

Spedicato M. T., Massutí E., Mérigot B., Tserpes G., Jadaud A. \& Relini G. 2019. The MEDITS trawl survey specifications in an ecosystem approach to fishery management. Scientia Marina, $83,9-20$.

Stamatakis A. 2014. RAxML version 8: a tool for phylogenetic analysis and post-analysis of large phylogenies. Bioinformatics 30(9), 1312-1313.

PeerJ reviewing PDF | (2021:04:59975:2:0:NEW 2 Jul 2021) 
1467 Tabachnick K. P. 2002. Family Rossellidae Schulze, 1885. In Hooper JNA and van Soest RWM 1468 eds, Systema Porifera. A Guide to the Classification of Sponges, vol. 2. New York, NY: Kluwer 1469 Academic/Plenum, pp. 1441-1505.

1470 Topsent E. 1890. Notice préliminaire sur les spongiaires recueillis durant les campagnes de 1471 l'Hirondelle. Bulletin de la Société zoologique de France, 15, 26-32, 65-71.

1472 Topsent, E. 1892. Contribution à l'étude des Spongiaires de l'Atlantique Nord Golfe de 1473 Gascogne, Terre-Neuve, Açores. Résultats des campagnes scientifiques accomplies par le Prince 1474 Albert I. Monaco. 2: 1-165, pls I-XI.

1475 Topsent E. 1895. Campagnes du yacht Princess Alice. Notice sur les spongiaires recueillis en 14761894 et 1895. Bulletin de la Société Zoologique de France, 20, 213-216.

1477 Topsent E. 1904. Spongiaires des Açores. Résultats des campagnes Scientifiques accomplies par 1478 le Prince Albert I. Monaco, 25, 1-280

1479 Topsent E. 1925. Etude des Spongiaires du Golfe de Naples. Archives de Zoologie 1480 expérimentale et générale, 635, 623-725

1481 Topsent E. 1928. Spongiaires de l'Atlantique et de la Méditerranée provenant des croisières du 1482 Prince Albert ler de Monaco. Résultats des campagnes scientifiques accomplies par le Prince 1483 Albert I. Monaco, 74, 1-376, pls I-XI.

1484 Trainito E., Baldacconi R. \& Mačić V. 2020. All-around rare and generalist: countercurrent 1485 signals from the updated distribution of Calyx nicaeensis Risso, 1826 Porifera, Demospongiae. 1486 Studia Marina, 33, 1.

1487 Uitz J., Stramski D., Gentili B., D’Ortenzio F. \& Claustre H. 2012. Estimates of phytoplankton 1488 class-specific and total primary production in the Mediterranean Sea from satellite ocean color 1489 observations. Global Biogeochem. Cycles, 26, GB2024.

1490 Uriz M. J. 1984. Material para la fauna de esponjas ibéricas: nuevas senalizaciones de 1491 Demosponjas en nuestras costas. Actas do IV Simposio ibérico de estudos do benthos marinho, $14923,131-140$.

1493 Vacelet J. 1961. Spongiaires Démosponges de la région de Bonifacio Corse. Recueil des Travaux 1494 de la Station marine d'Endoume, 22 36, 21-45.

1495 Vacelet J. 1969. Eponges de la Roche du Large et de l'étage bathyal de Méditerranée récoltes de 1496 la soucoupe plongeante Cousteau et dragages. Mémoires du Muséum national d'Histoire 1497 Naturelle 59, 145-219.

1498 Valisano L., Pozzolini M., Giovine M. \& Cerrano C. 2012. Biosilica deposition in the marine 1499 sponge Petrosia ficiformis Poiret, 1789: the model of primmorphs reveals time dependence of 1500 spiculogenesis. In Maldonado M., Becerro M.A., Turon X., and Uriz M.J., eds Ancient Animals, 1501 New Challenges. Dordrecht: Springer, pp. 259-273. 
1502 Vân Le H. L., Lecointre G. \& Perasso R. 1993. A 28S rRNA-based phylogeny of the 1503 gnathostomes: first steps in the analysis of conflict and congruence with morphologically based 1504 cladograms. Molecular phylogenetics and evolution, 21, 31-51.

1505 Van Soest R.W.M.; Hooper J.N.A. 1993. Taxonomy, phylogeny and biogeography of the marine 1506 sponge genus Rhabderemia Topsent,1890 Demospongiae, Poecilosclerida. Pp. 319-351. In: Uriz, 1507 M.-J. \&Rützler, K. Eds, Recent Advances in Ecology and Systematics of Sponges. Scientia 1508 Marina. 57 4, 273-432.

1509 Abdul Wahab M. A., Wilson N. G., Prada D., Gomez O. \& Fromont J. 2020. Molecular and 1510 morphological assessment of tropical sponges in the subfamily Phyllospongiinae, with the 1511 descriptions of two new species. Zoological Journal of the Linnean Society.

1512 White M. \& Mohn C. 2004. Seamounts: a review of physical processes and their influence on the 1513 seamount ecosystem. OASIS EU Project Report, 37 pp.

1514 Wörheide G. 2006. Low variation in partial cytochrome oxidase subunit I COI mitochondrial 1515 sequences in the coralline demosponge Astrosclera willeyana across the Indo-Pacific. Marine 1516 Biology 148, 907-912.

1517 Würtz M. \& Rovere M. 2015. Atlas of the Mediterranean seamounts and seamount-like 1518 structures. Gland, Switzerland: IUCN. 
Figure 1

Map of the studied area showing the location of the sampling stations of beam trawl (BT), bottom trawl type GOC73 (GOC), rock dredge (RD) and remote operated vehicle (ROV). The characteristics of these sampling stations are shown in Table 1.
(A) general view of the Balearic Islands. (B) detail of Ses Olives. (C) detail of Ausias March.
(D) detail of Emile Baudot. 


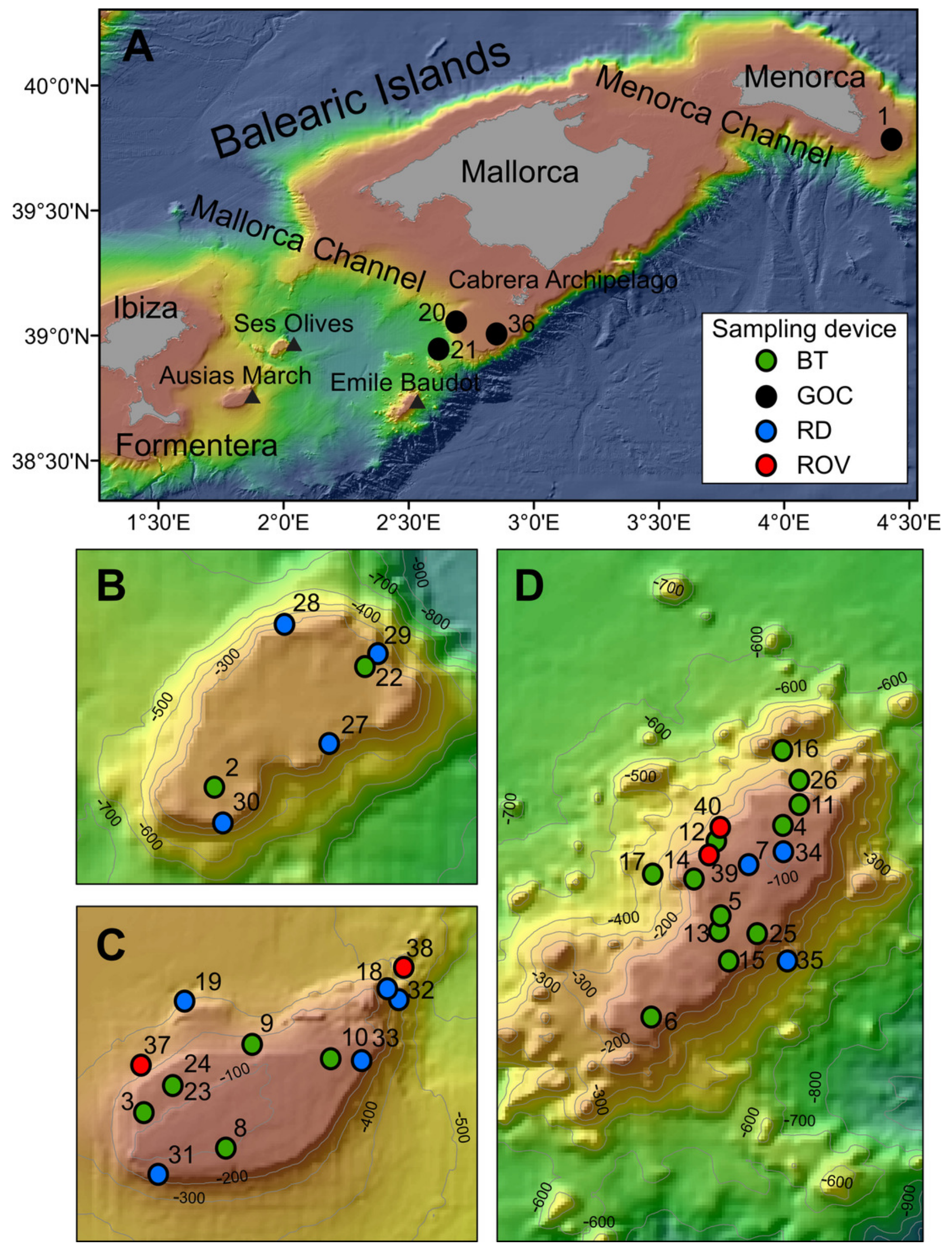




\section{Figure 2}

Remote Operated Vehicle (ROV) images of the sponge fauna from the seamounts of the Mallorca Channel, Ses Olives (SO), Ausias March (AM) and Emile Baudot (EB).

(A) specimen of Polymastia polytylota collected at $409 \mathrm{~m}$ depth in AM. (B) Holotype of Foraminospongia balearica sp. nov. collected at $129 \mathrm{~m}$ depth in the AM summit. (C) specimen of Phakellia ventilabrum collected at $132 \mathrm{~m}$ depth in the EB summit. (D) uncollected specimen of Phakellia sp. at $374 \mathrm{~m}$ depth in the north knoll of AM. (E) specimen of Haliclona (soestella) fimbriata collected at $131 \mathrm{~m}$ depth in the EB. (F) rhodolith bed at 110 $m$ depth in the summit of AM, with different sponge species, including $F$. balearica sp. nov. (arrow), (G) uncollected specimen of Calyx cf. tufa at $106 \mathrm{~m}$ depth in the summit of AM, (H) coralligenous bottom at $97 \mathrm{~m}$ depth in the summit of AM, with several sponges, including $\mathrm{F}$. balearica sp. nov. (arrow). 

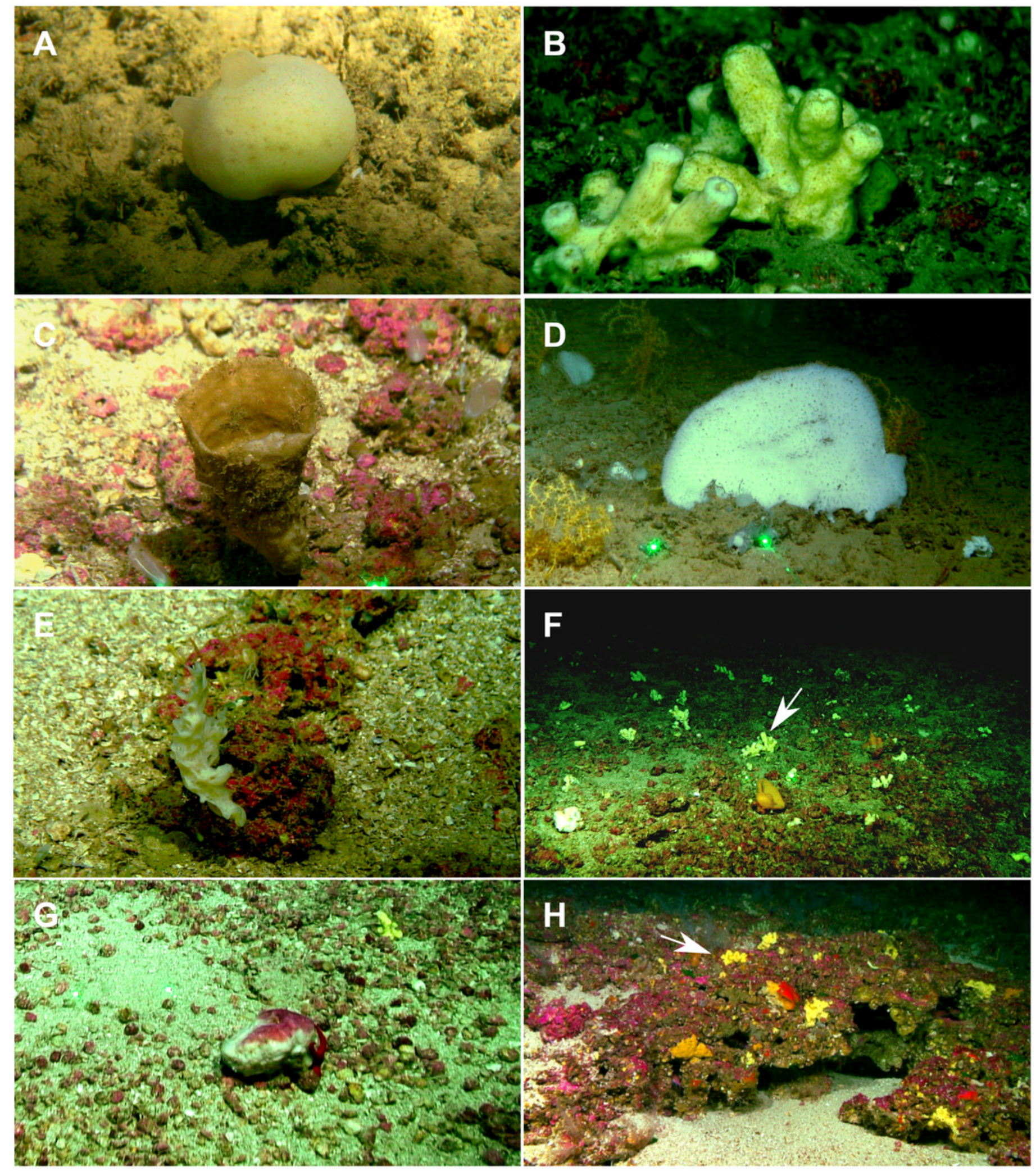


\section{Figure 3}

Foraminospongia balearica sp. nov.

(A) habitus of CFM-IEOMA-7356/i802 (holotype) in fresh state, with (B), detail of the oscula and the dermal membrane $(\mathrm{dm})$ and $(\mathrm{C})$, macroscopic view of the grooves at the skin.

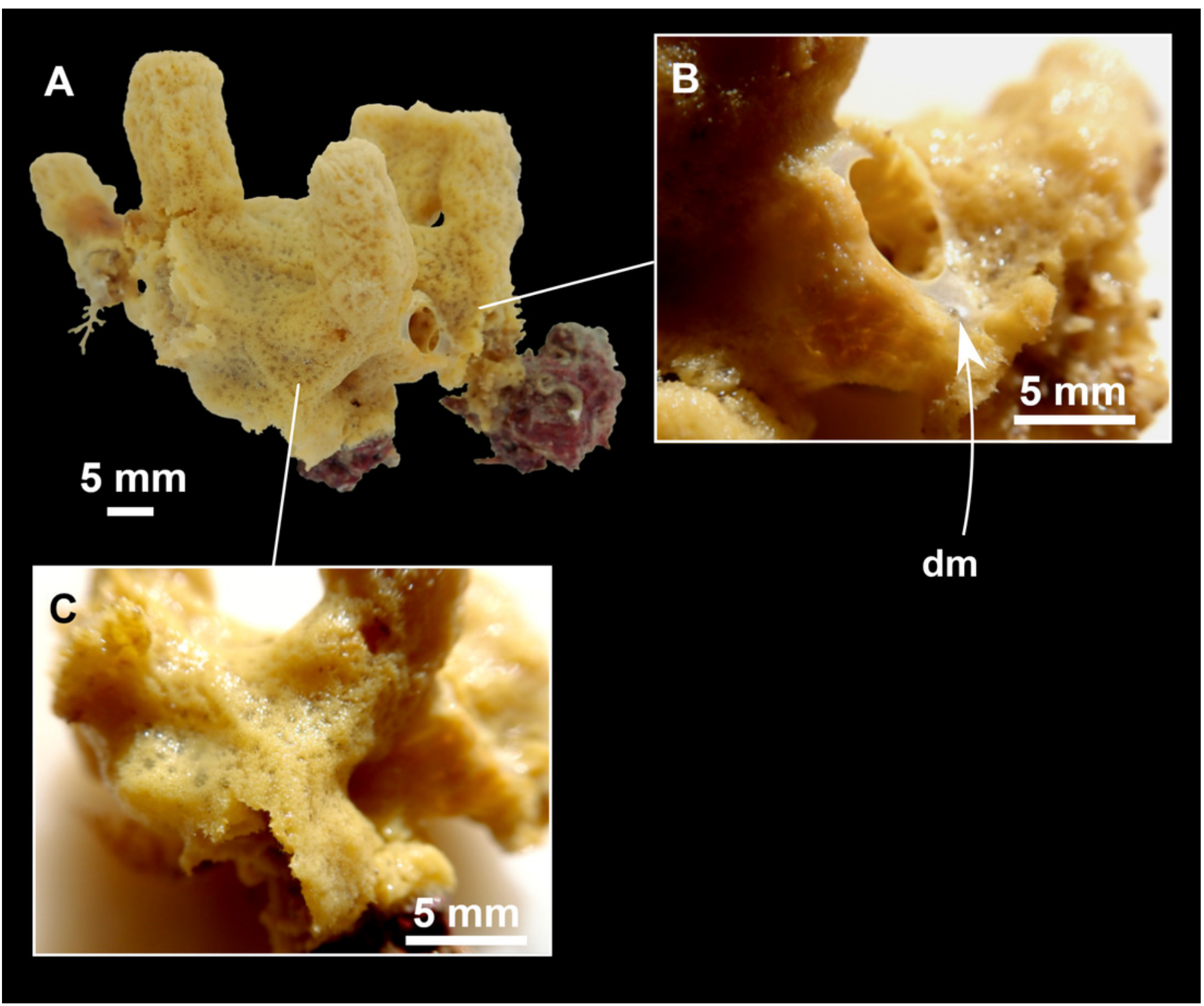


Figure 4

Skeletal arrangement of Foraminospongia balearica sp. nov., CFM-IEOMA-7356/i802 (holotype).

(A-C) tangential images of the surface, showing the dermal membrane (dm). (D-E) transversal sections. 


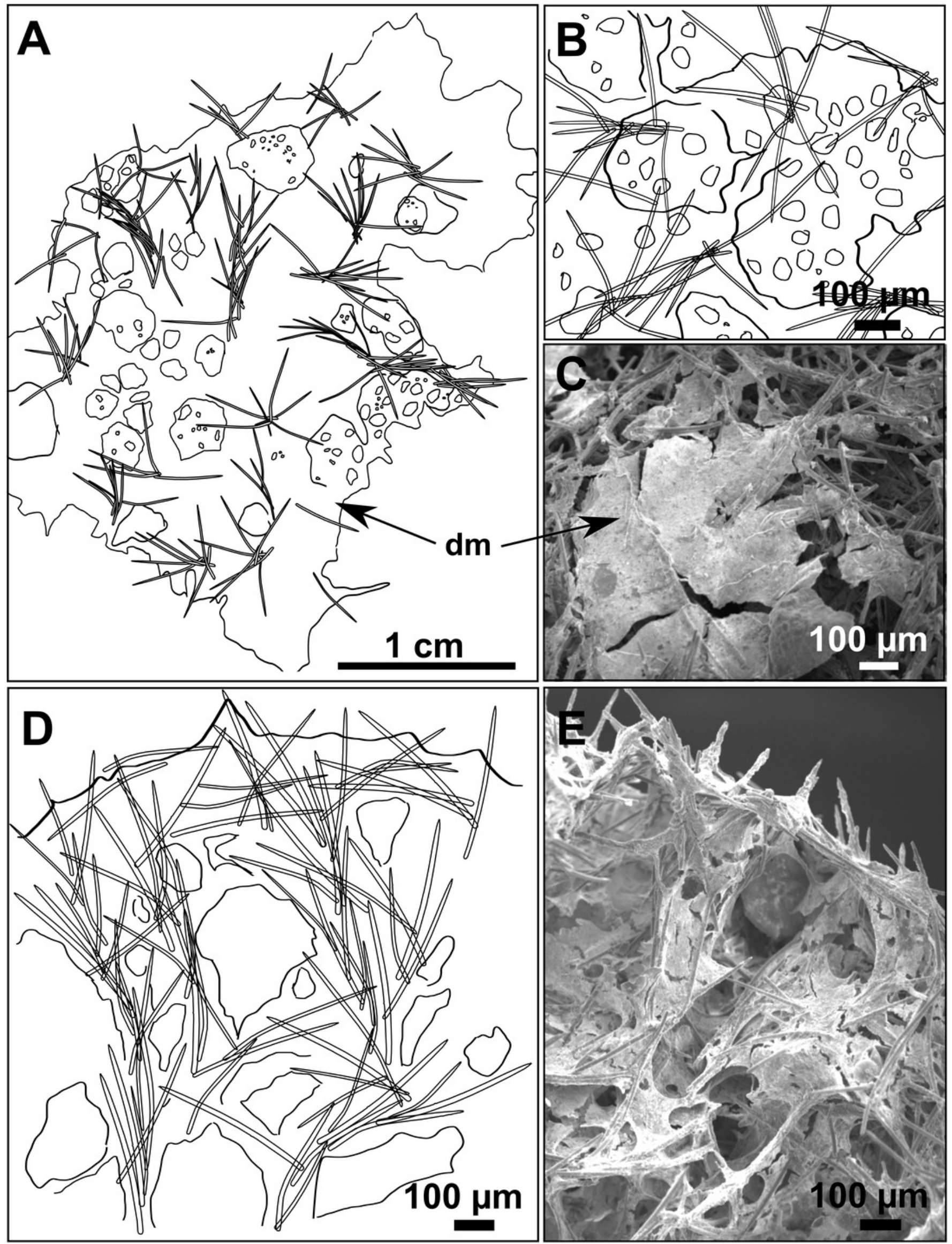


Figure 5

SEM images of the spicules from Foraminospongia balearica sp. nov. CFMIEOMA-7358/i293_1 (paratype).

(A-D) styles. (E) rhabdostyles. (F) oxea. 


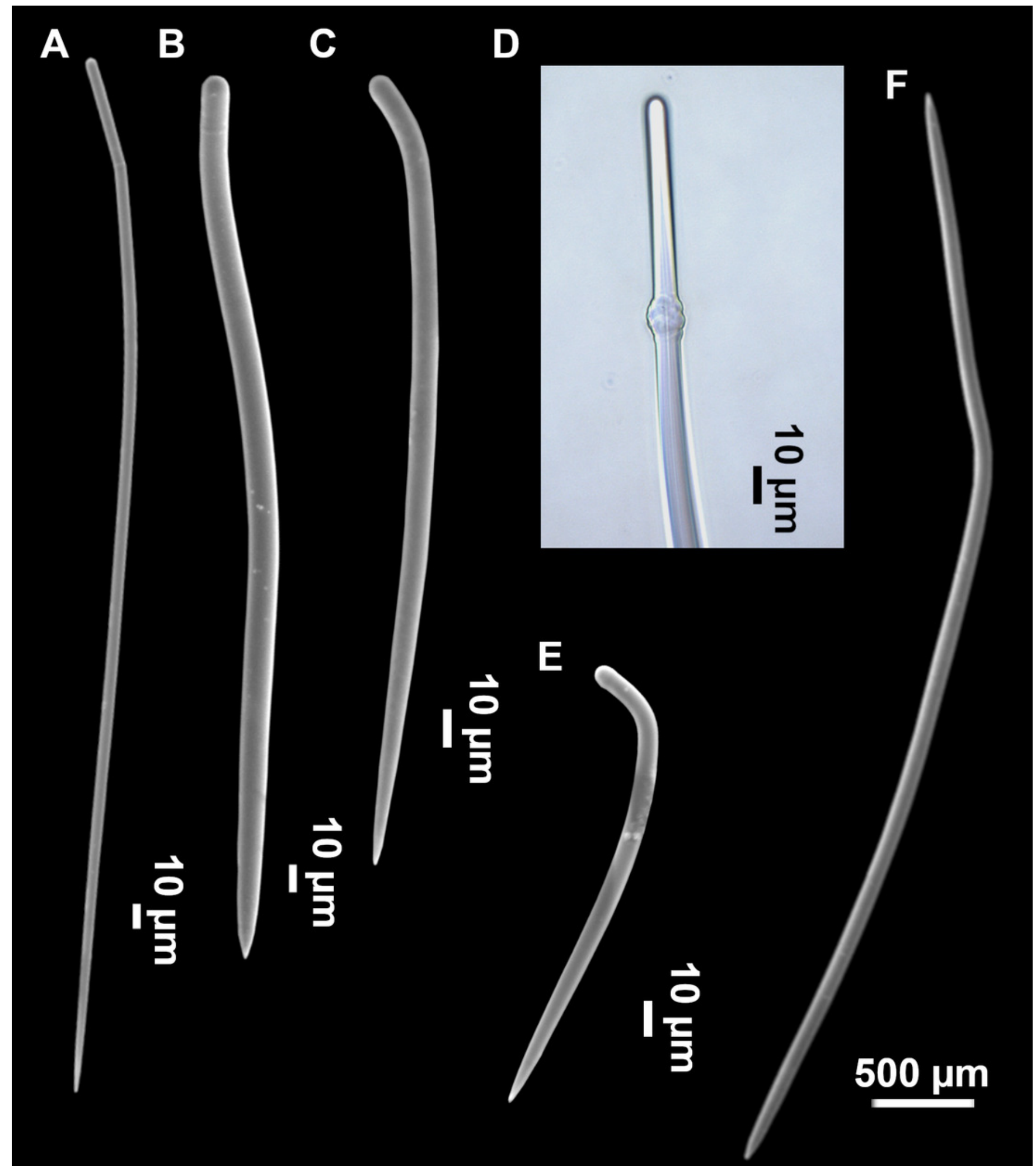




\section{Figure 6}

Foraminospongia minuta sp. nov.

(A) habitus of CFM-IEOMA-7362/i439 (holotype) on fresh state. (B) on deck image of CFMIEOMA-7363/i474 (paratype). (C) optic microscope image of the tangential skeleton of the holotype. (D) schematic illustration of the choanosome of the holotype. (E-F) styles. (G-H) rhabdostyles. 


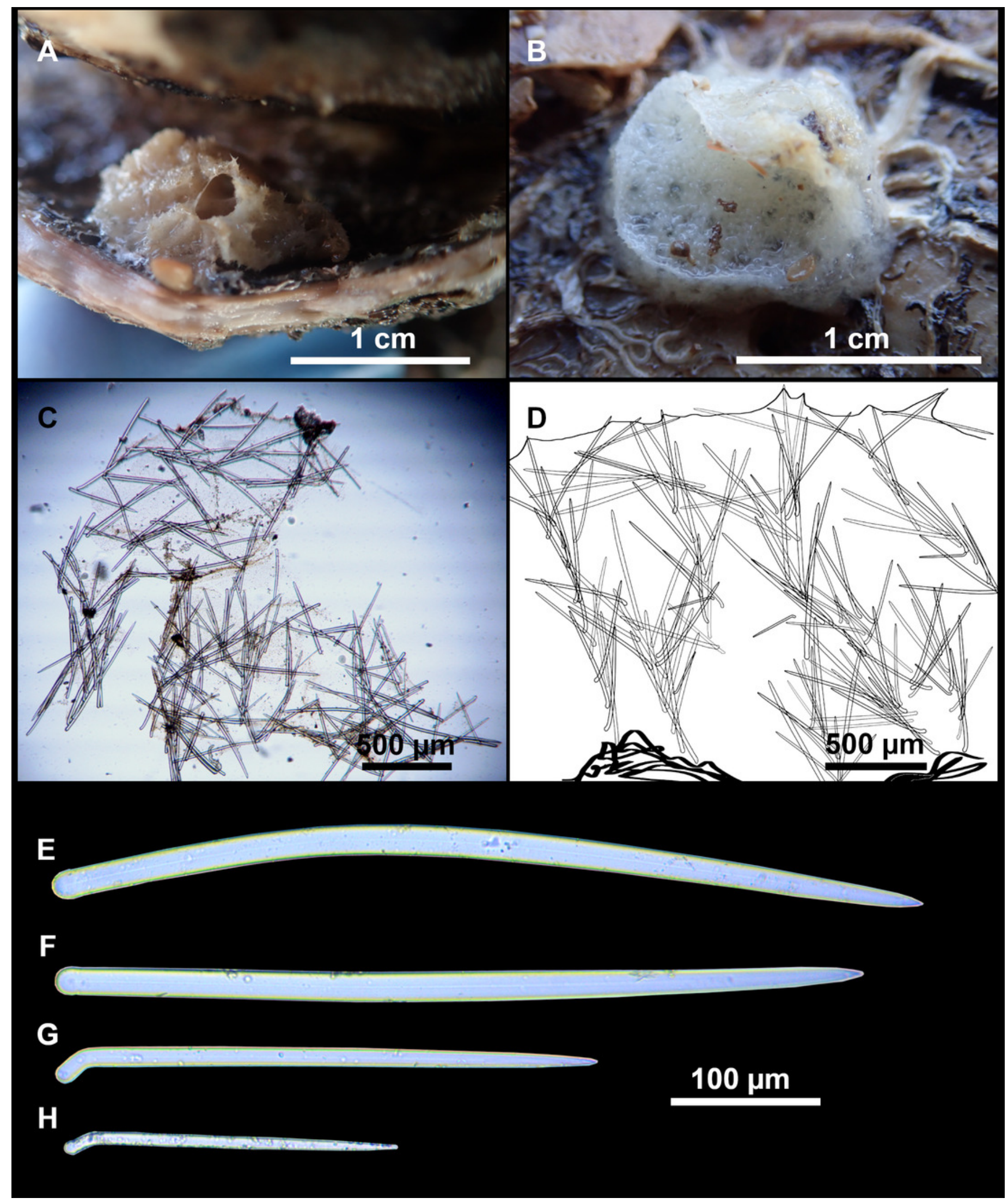




\section{Figure 7}

Phylogenetic tree topology for specimens of Foraminospongia balearica sp. nov., Foraminospongia minuta sp. nov. described in the present study and other related Agelasids.

The three was constructed with Maximum likelihood and Bayesian inference, based on COI (A) and $28 \mathrm{~S}$ (B) fragments. Posterior probabilities and bootstrap support values are shown at the nodes. A sequence of Suberites domuncula and Suberites ficus are used as outgroups in both trees. 


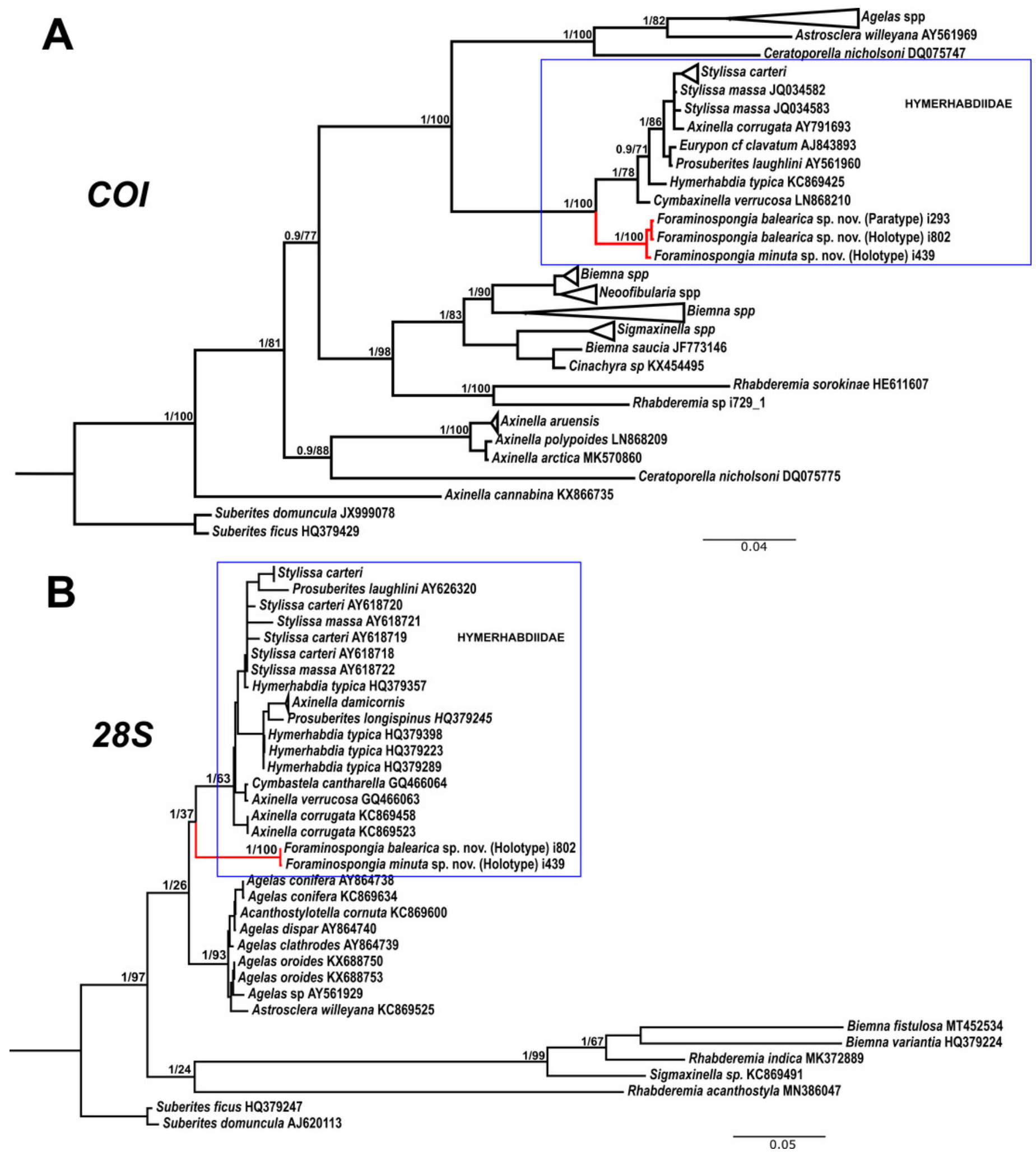




\section{Figure 8}

Axinella spatula Sitjà \& Maldonado, 2014.

(A) photograph of fresh material deposited under CFM-IEOMA-7364-7366/i338_1A-1C. (B)

habitus of CFM-IEOMA-7366/i338_1C preserved in EtOH. (C) SEM images of the skeletal structure of CFM-IEOMA-7366/i338_1C with detail of the inner ectosomal layer, with trichodragmata (tri). (D) long styles with (D1) subterminal swelling. (E) regular shaped style. (F) style with rhabdose modification. (G) oxea asymmetrically curved. $(\mathrm{H})$ oxea centrocurved.

(I) oxea centrotylota. (J-K) small oxeas. 


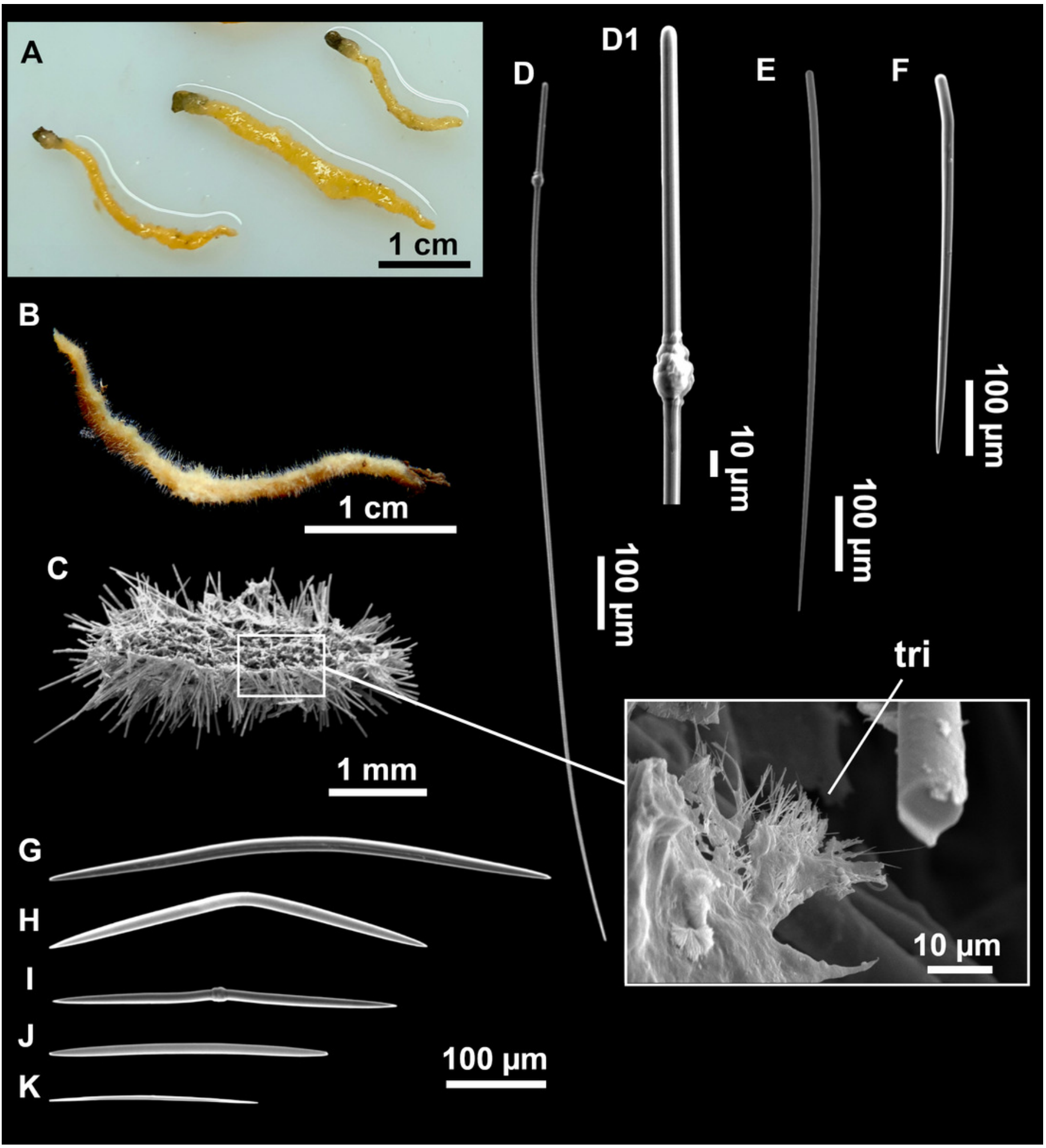


Figure 9

Heteroxya cf. beauforti.

(A) habitus of CFM-IEOMA-7380/i726 in fresh state. (B) habitus of CFM-IEOMA-7382/i461 in fresh state (large patch).

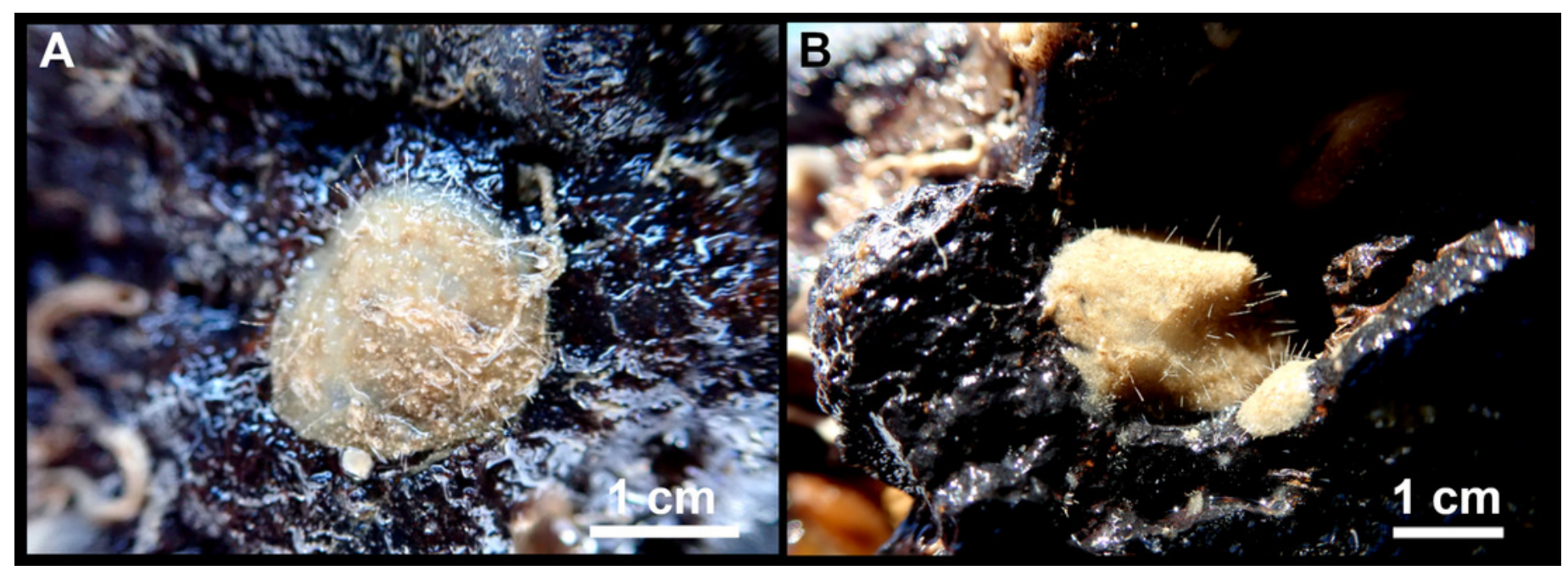




\section{Figure 10}

Schematic illustration of Heteroxya cf. beauforti skeleton in transversal section

(A) general view. (B) body arrangement on a thick area. (C) body arrangement on a thin area. (ox I) oxea I. (ox II) oxea II. (bl) basal lamina. (ect) ectosome. (ch) choanosome. (tr) spicule tracks. 


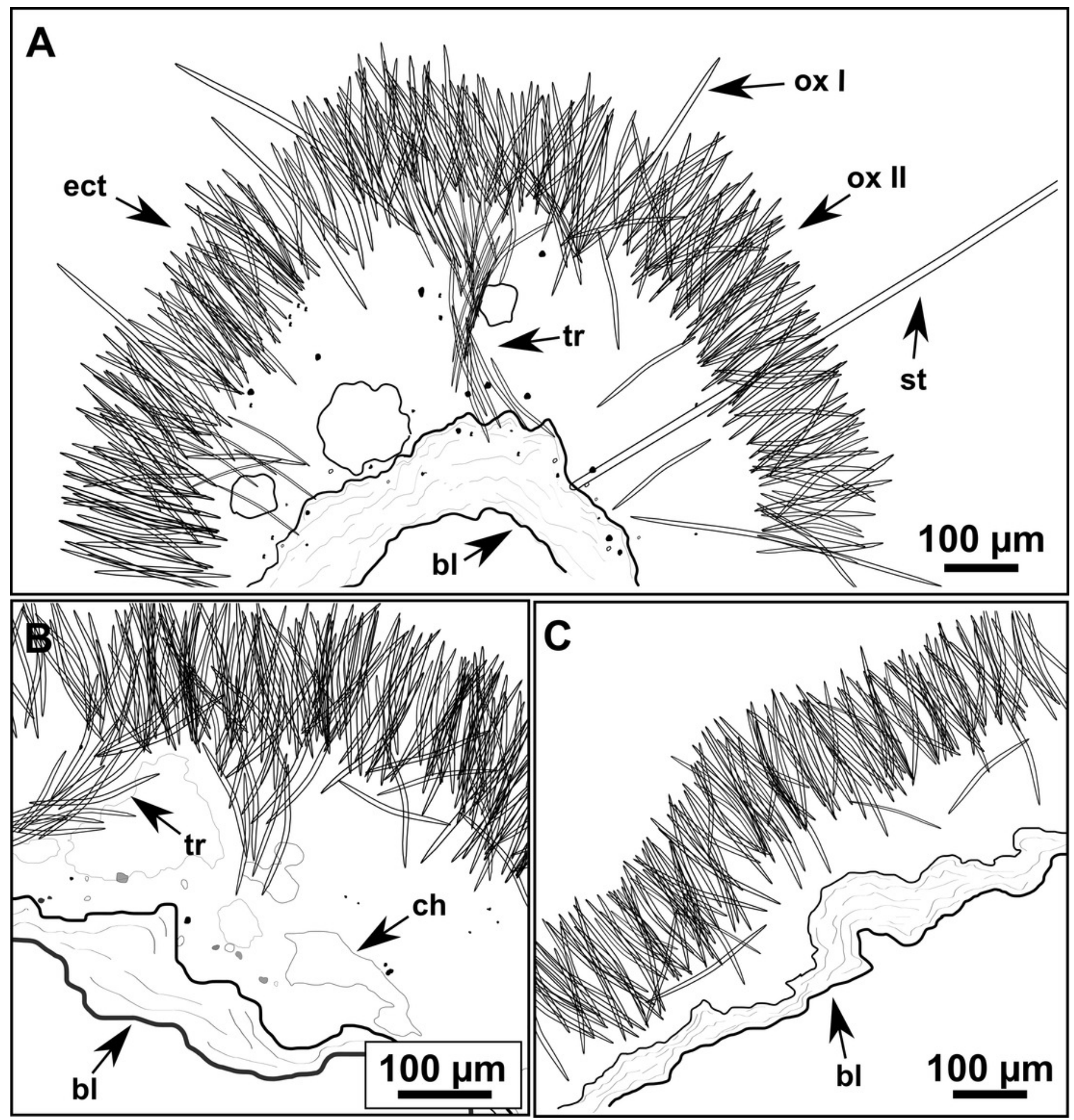




\section{Figure 11}

Spicules of Heteroxya cf. beauforti.

(A) large oxeas I. (B) small oxeas II. (C-D) detail of polyactinal teratogenic modifications of

oxeas II. (I) optical microscope image of spicules from the holotype, showing small oxeas and a style (St).

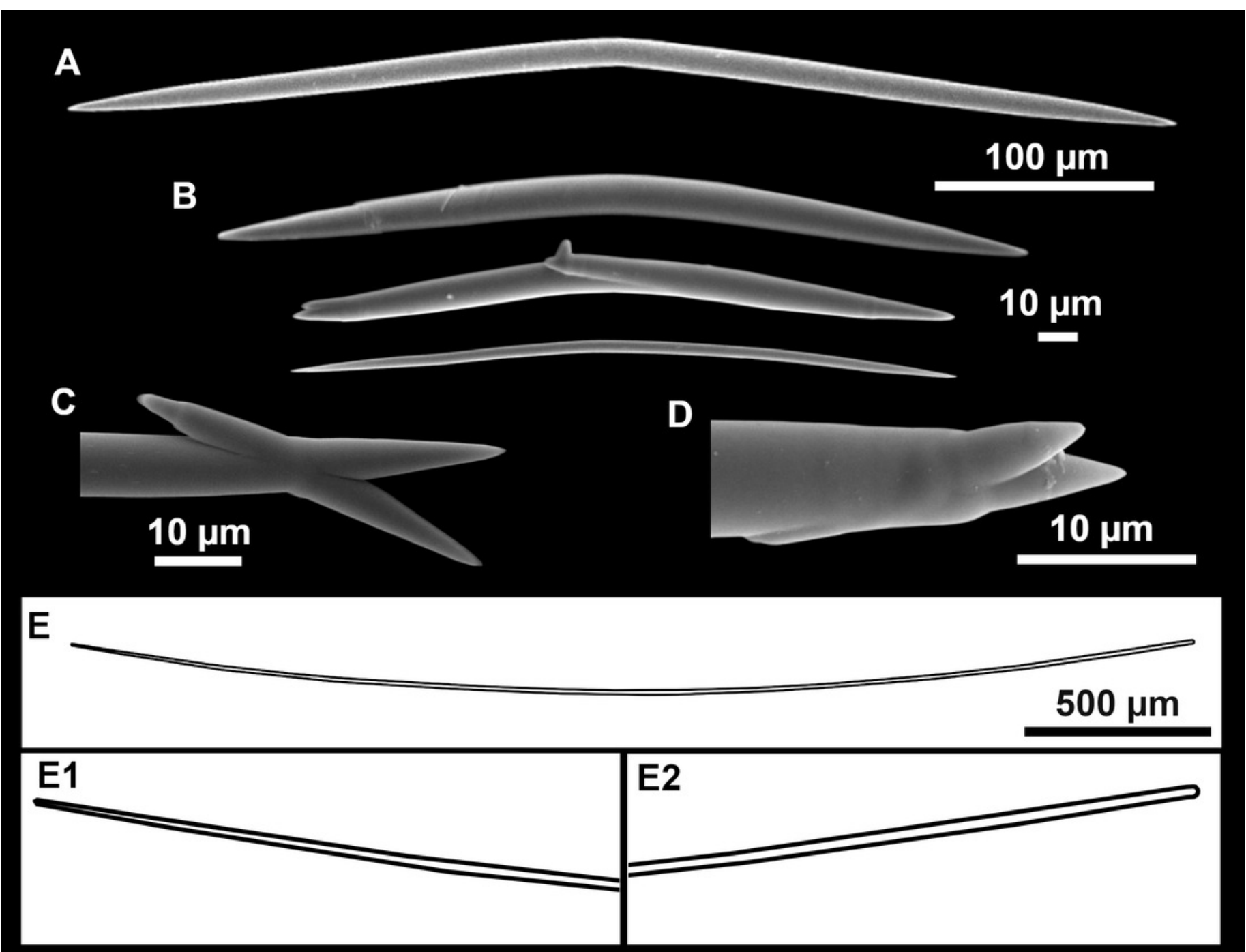




\section{Figure 12}

Paratimea massutii sp. nov.

(A-B) habitus of the holotype CFM-IEOMA-7383/i403 in fresh state, on its upper $(A)$ and lower (B) sides. (C) habitus of the paratype CFM-IEOMA-7384/i420 preserved in EtOH. (D) schematic illustration of a transversal section of the holotype. (E-J) SEM images of the Holotype. (E) oxea I, (F) oxea I (auxiliar spicule). (G-J) oxyasters (all with same bar scale). 


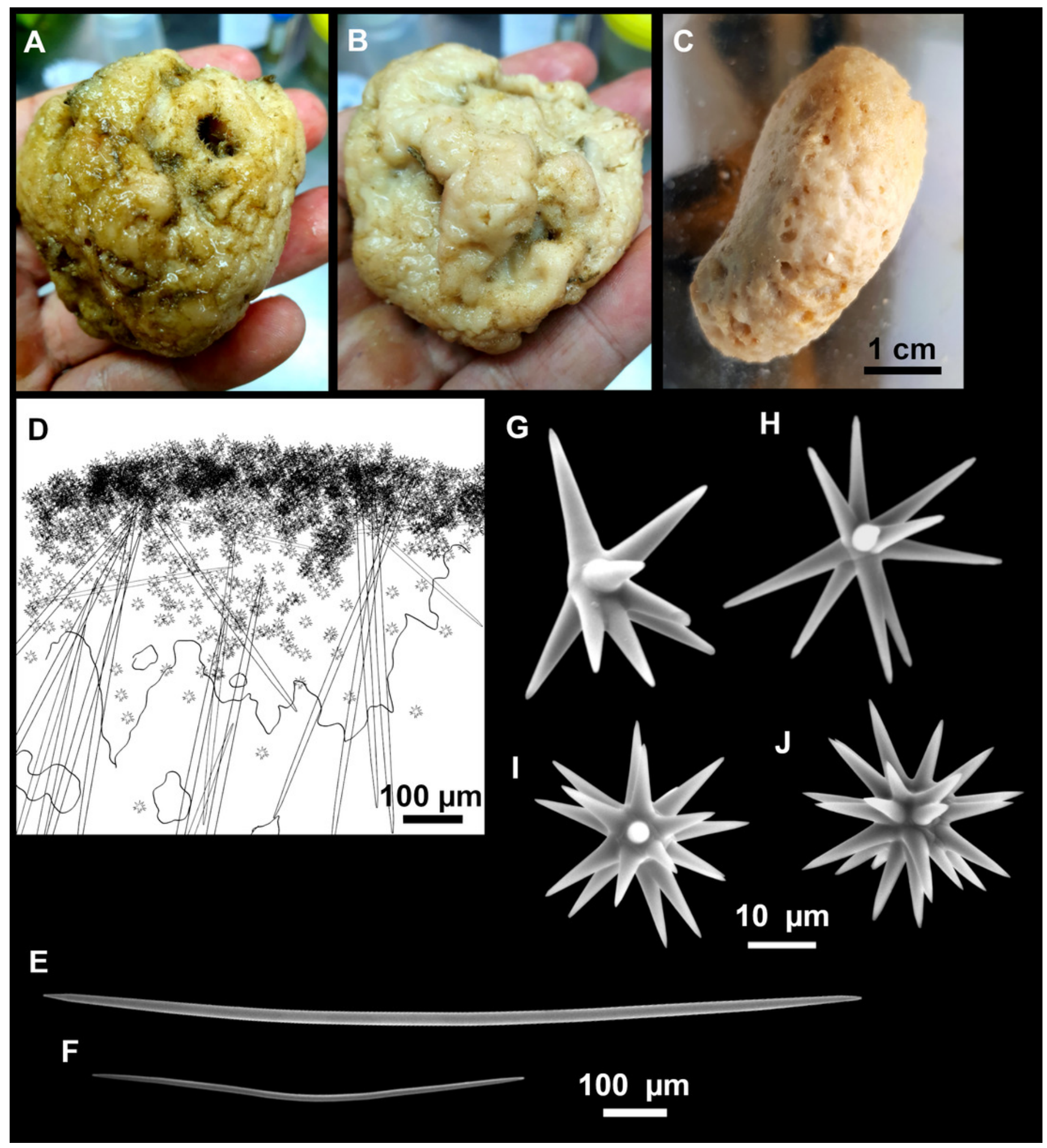




\section{Figure 13}

Dragmatella aberrans (Topsent, 1890).

(A) habitus of CFM-IEOMA-7388/i175 preserved in EtOH. (B-D) SEM images of the skeletal structure of CFM-IEOMA-7388/i175. (B) general view of the skeletal arrangement. (C) detail of the ectosome. (D) view of the ascending choanosomal tylostyle tracks. (E-E1) mycalostyles. (F) raphides with (F1) detail of the hook-shaped ends and central irregularities. 


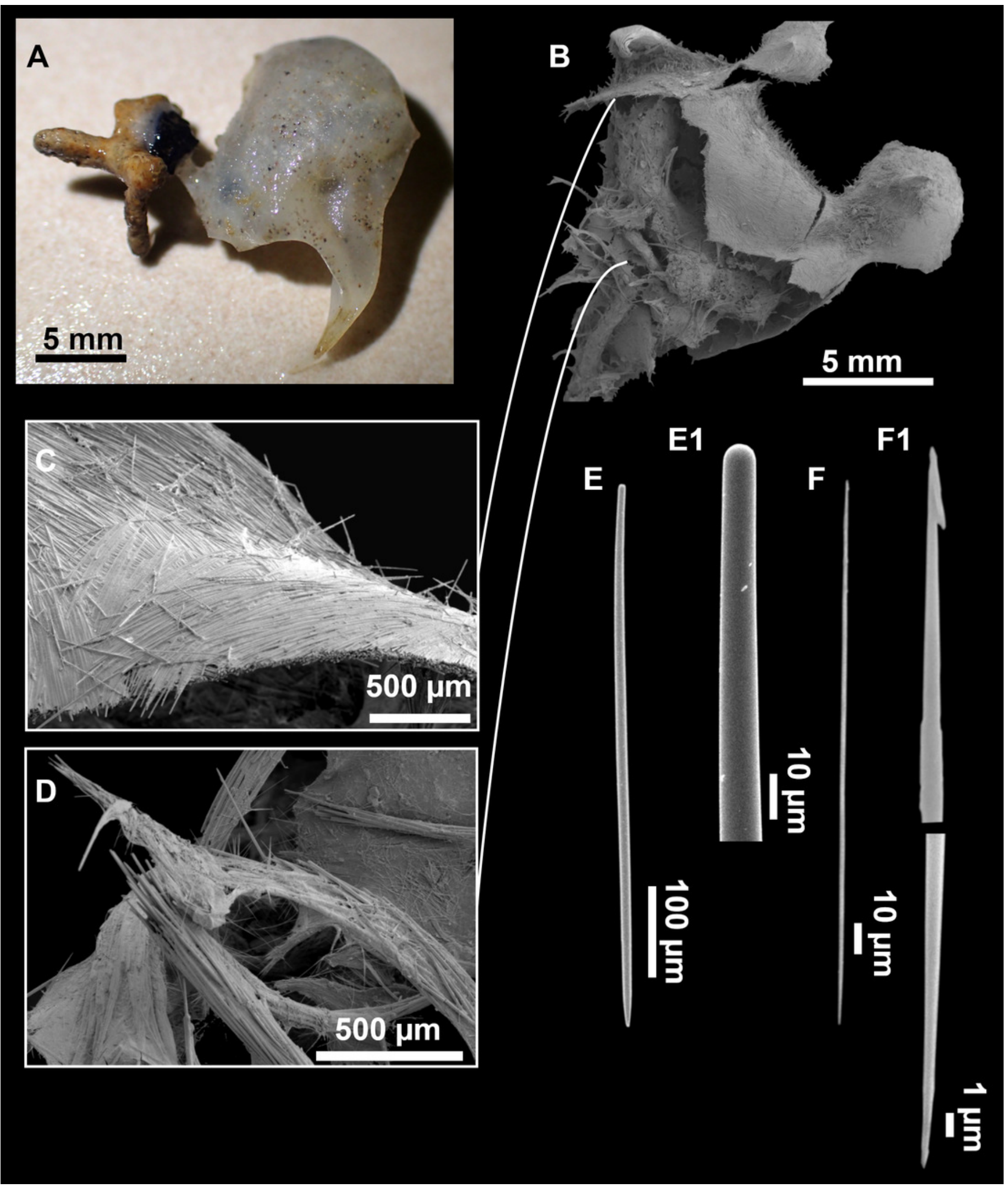




\section{Figure 14}

Petrosia (Petrosia) raphida Boury-Esnault, Pansini \& Uriz, 1994.

(A) habitus of CFM-IEOMA-7451/i242, preserved in EtOH. (B) SEM image of the choanosome.

(C) detail of a choanosomal chamber. (D) oxeas. (E) young stages of oxeas. (F-F1)

acanthoses raphides. (G) smooth raphides. 


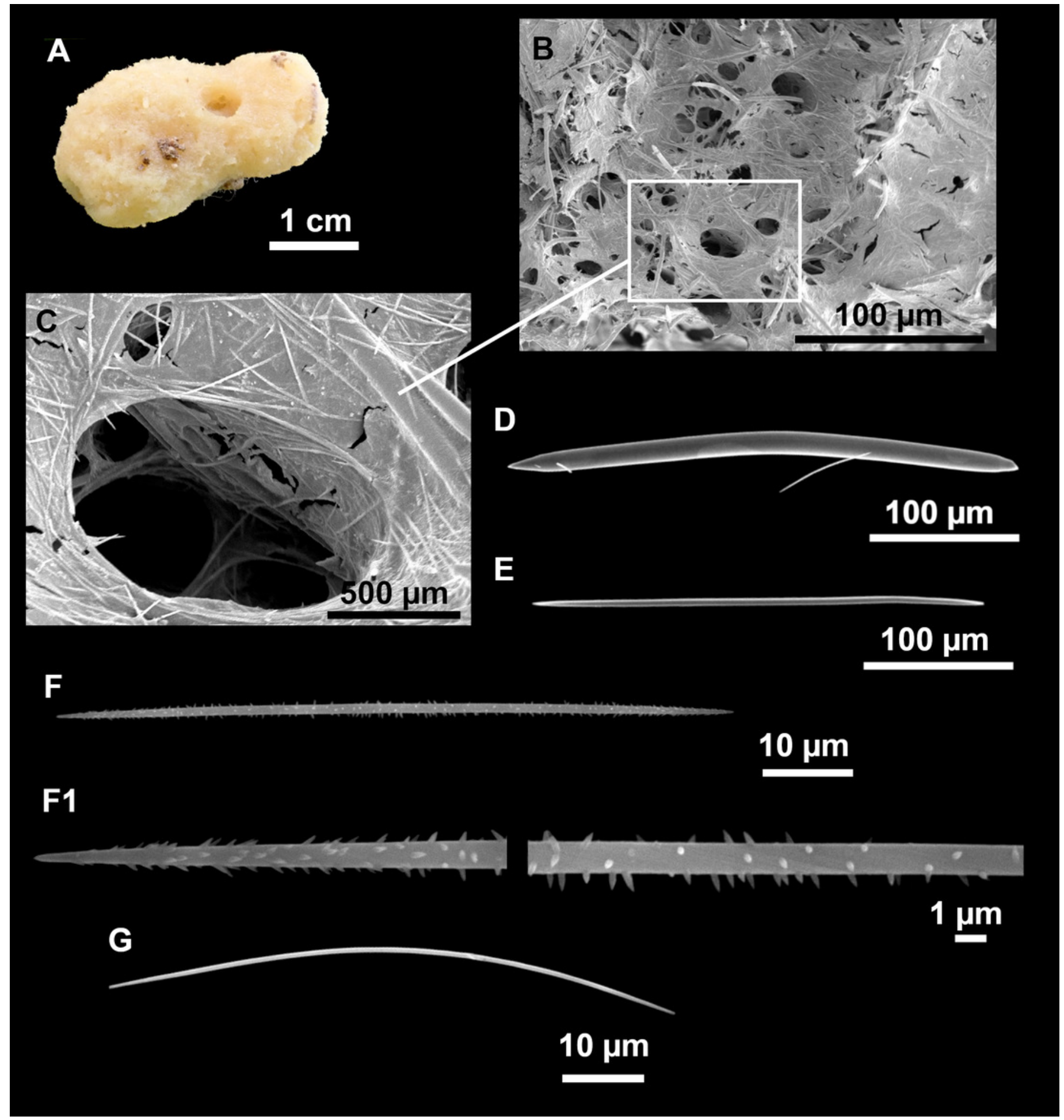




\section{Figure 15}

Calyx cf. tufa.

(A) habitus of CFM-IEOMA-7403/i525 in fresh state. (B) detail of the ectosome with poral areas. (C) view of a poral area of the ectosome with spherulous cells (arrow). (D) transversal section of the choanosome. (E) detail of the reticulation of the choanosome. (F-G) immature and mature oxeas, with (G1) detail of the tips of $(\mathrm{G})$. 


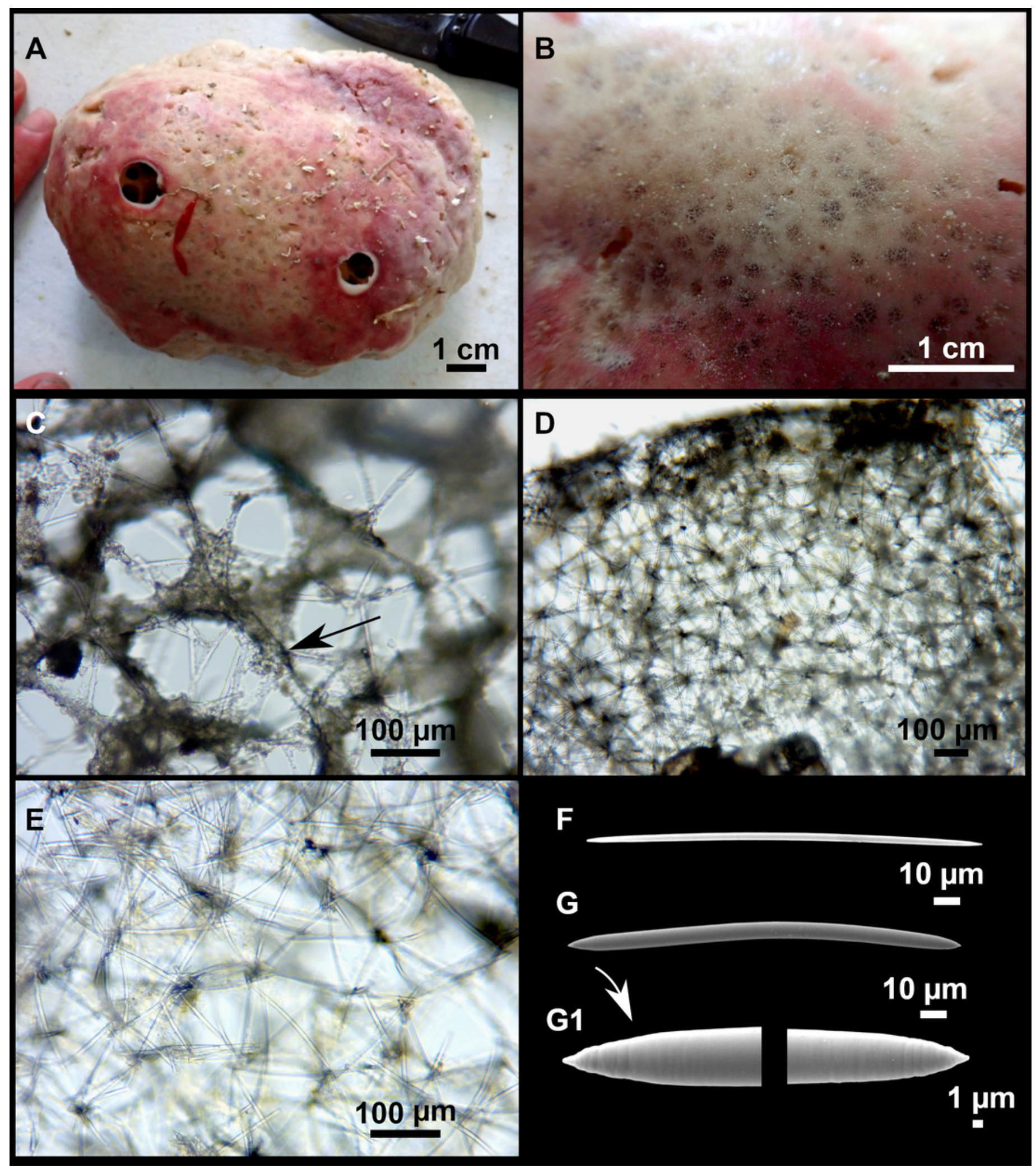


Figure 16

Melonanchora emphysema (Schmidt, 1875).

(A) habitus of CFM-IEOMA-7404/i573 on fresh state, attached to a rodolith. (B-C) tylotes. (D-E) spheranchoras. (F) anchorate isochela I. (G) anchorate isochela II. 


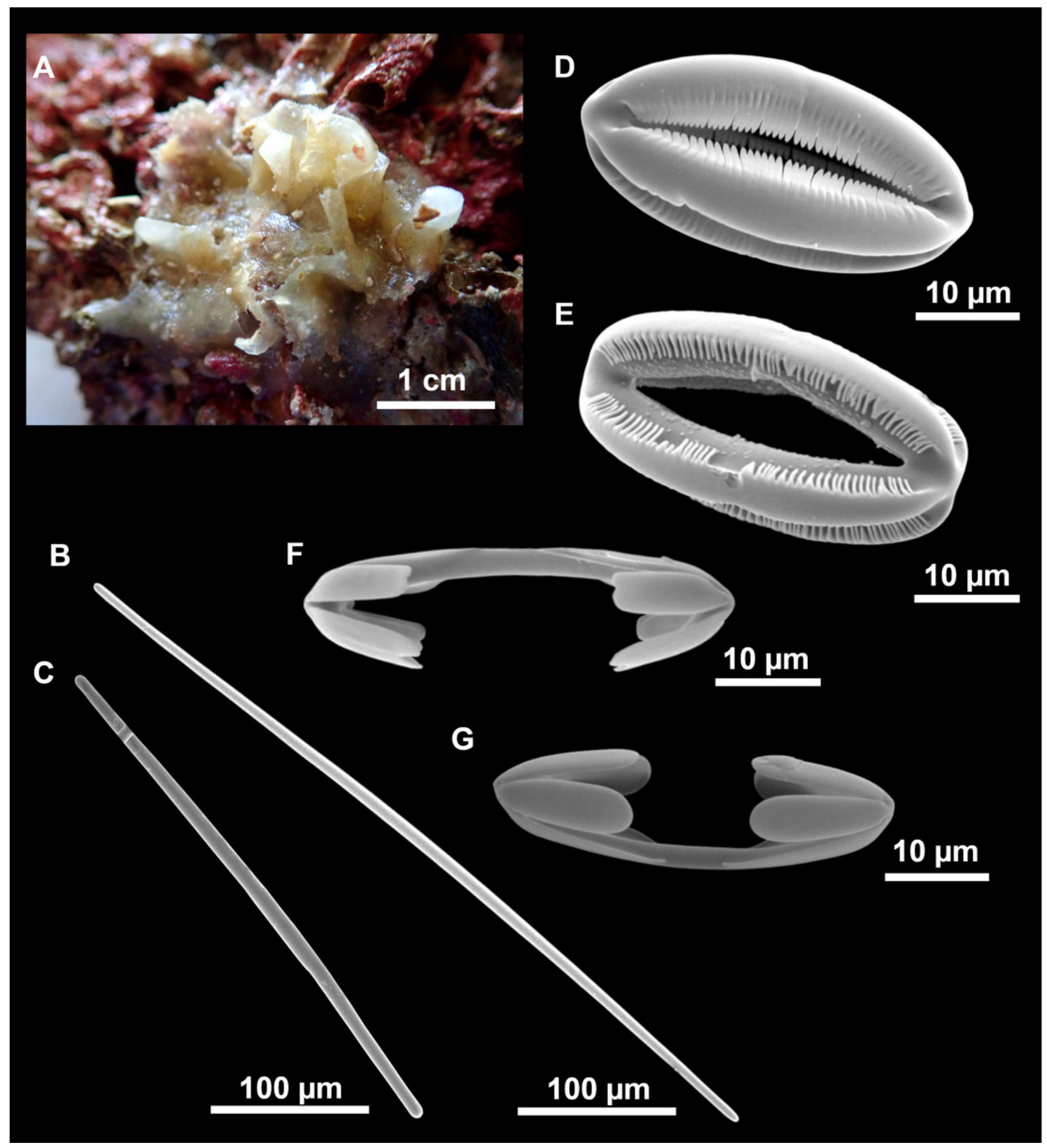




\section{Figure 17}

Polymastia polytylota Vacelet, 1969.

(A-B) habitus of CFM-IEOMA-7405/i810, on fresh state (A), and preserved in EtOH (B). (C-C1) principal subtylostyles with detail of the tyles in the shaft (arrows). (D) Intermediary tylostyles with (D1) detail of the head. (E) ectosomal tylostyles with (E1) detail of the head. 


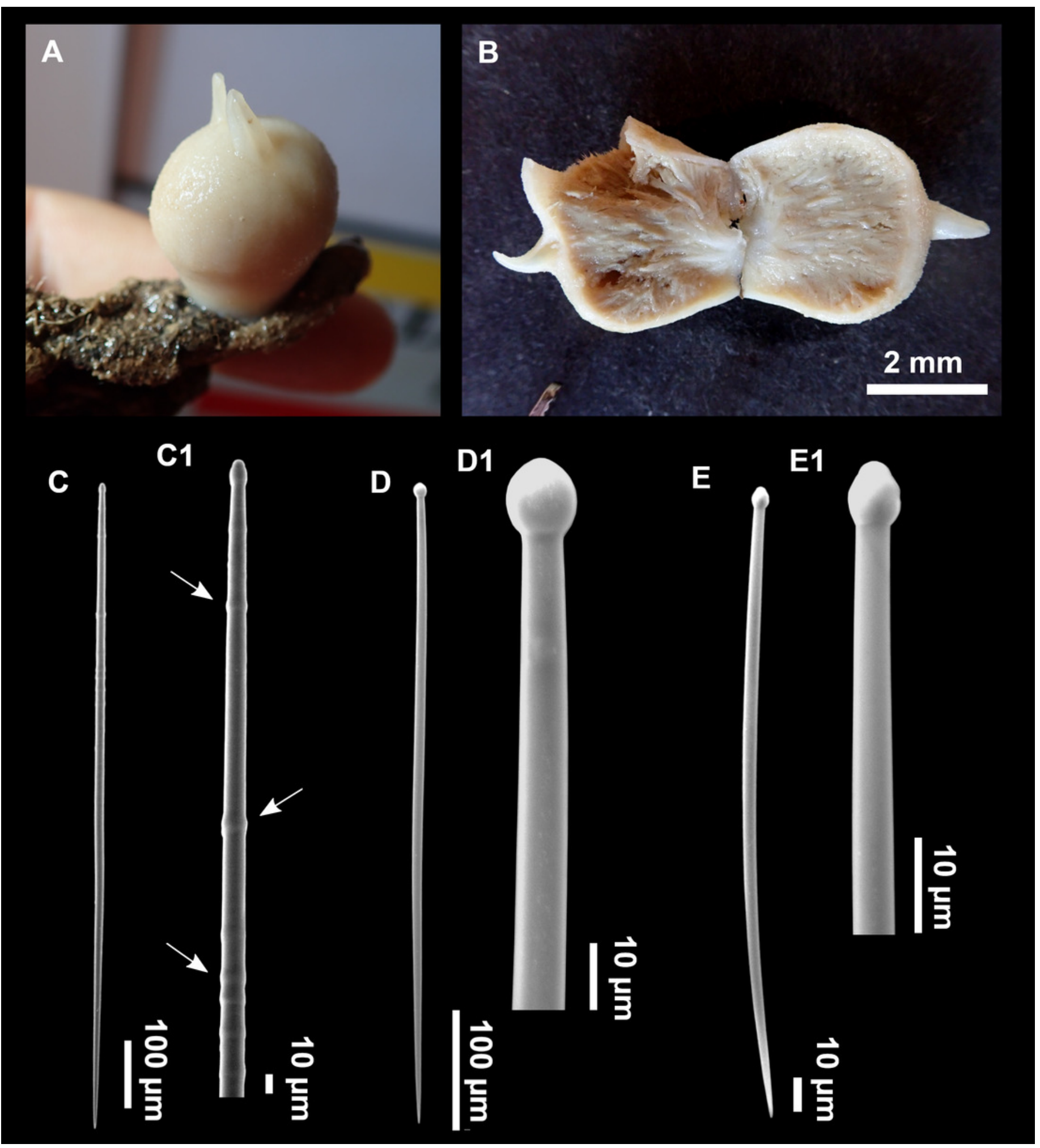




\section{Figure 18}

Pseudotrachya hystrix (Topsent, 1980).

(A) habitus of CFM-IEOMA-7407/i613 on fresh state. (B-B1) SEM images of the skeletal structure. (po) palisade of oxeas. (C-C1) anisoxeas. (D) microxeas. 


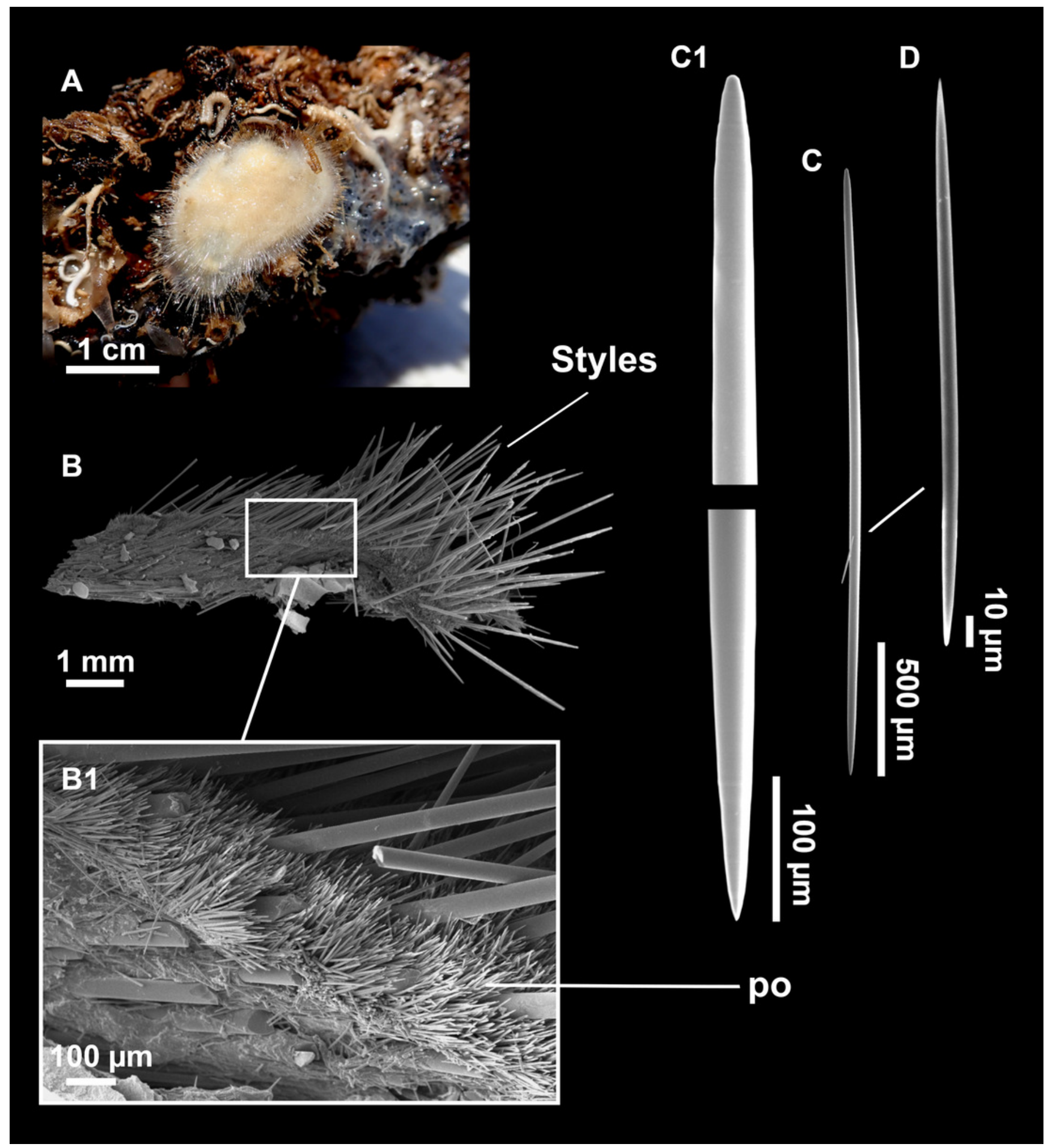




\section{Figure 19}

Lanuginella pupa Schmidt, 1870.

(A) habitus of CFM-IEOMA-7413/i286_2 (left), CFM-IEOMA-7412/i286_1 (middle), i286_3/CFMIEOMA-7414 (right) preserved in EtOH. (B-I) SEM images of spicules from CFM-

IEOMA-7412/i286_1. (B) choanosomal diactine with (B1) detail of the four central tubercles. (C) choanosomal hexactine. (D) hypodermal pentactine. (E) stauractine. (F-G) atriala hexactines with (G1) detail of the spines of $(\mathrm{G})$. (H) discohexaster. (I) agglomeration of discohexasters, with a strombiloplumicome (sp) beneath. 


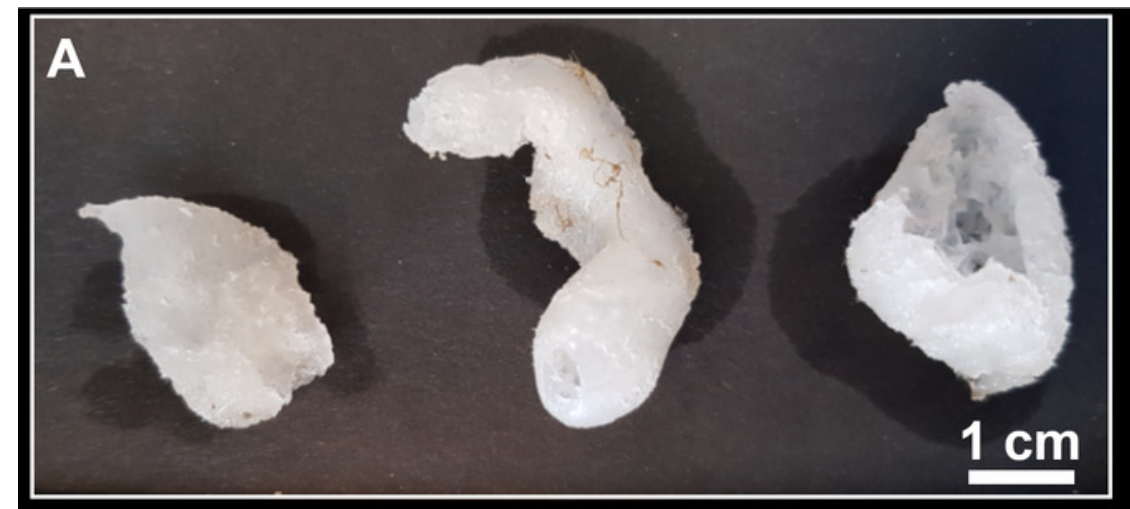

D
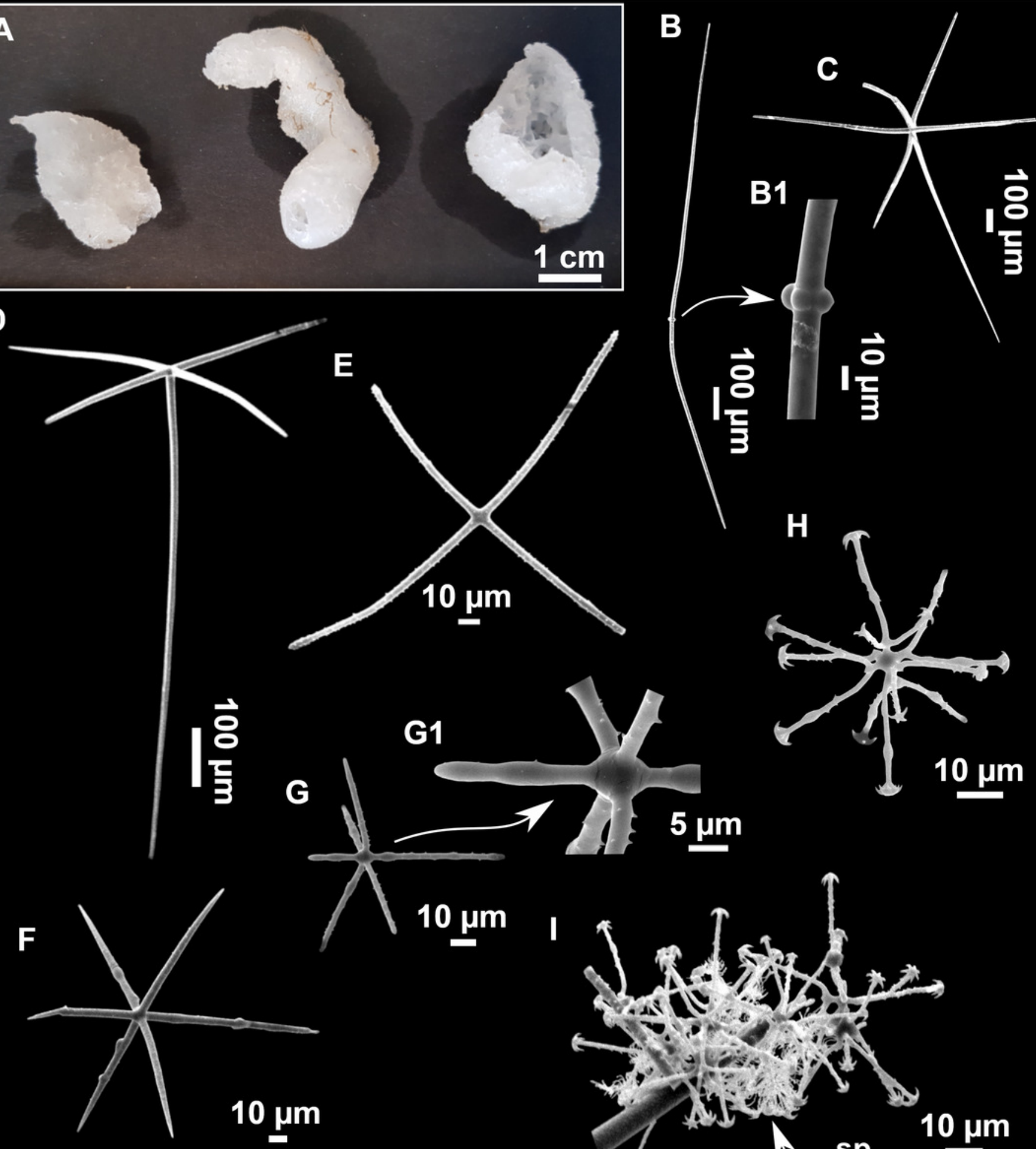

$10 \mu \mathrm{m} \quad$ I

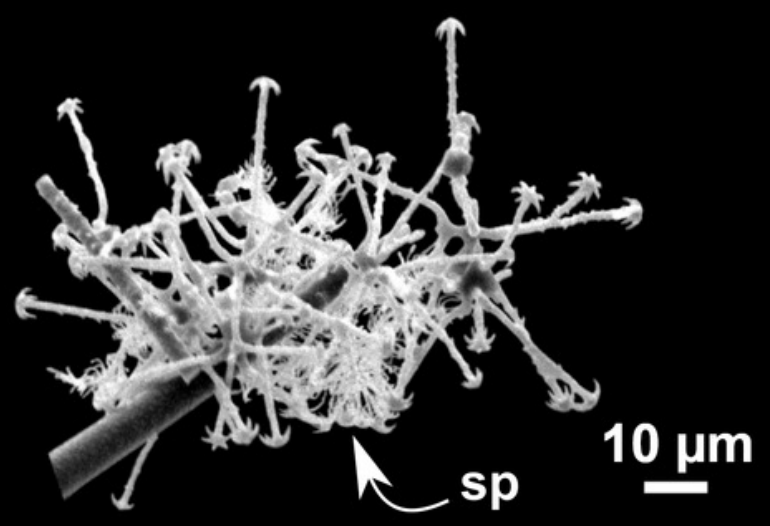




\section{Table $\mathbf{1}$ (on next page)}

Details of the sampling stations.

$\left(R_{\text {survey }}\right)$ reference number in the survey. $\left(R_{\text {study }}\right)$ correspondent reference in the present study. (GOC-73) experimental bottom trawl net. (BT) beam trawl. (DR) rock dredge. (ROV) Remote Operated Vehicle Liropus 2000. (SO) Ses Olives. (AM) Ausias March. (EB) Emile Baudot. (E Me) eastern Menorca. (SW Ca) south-western Cabrera Archipelago. 


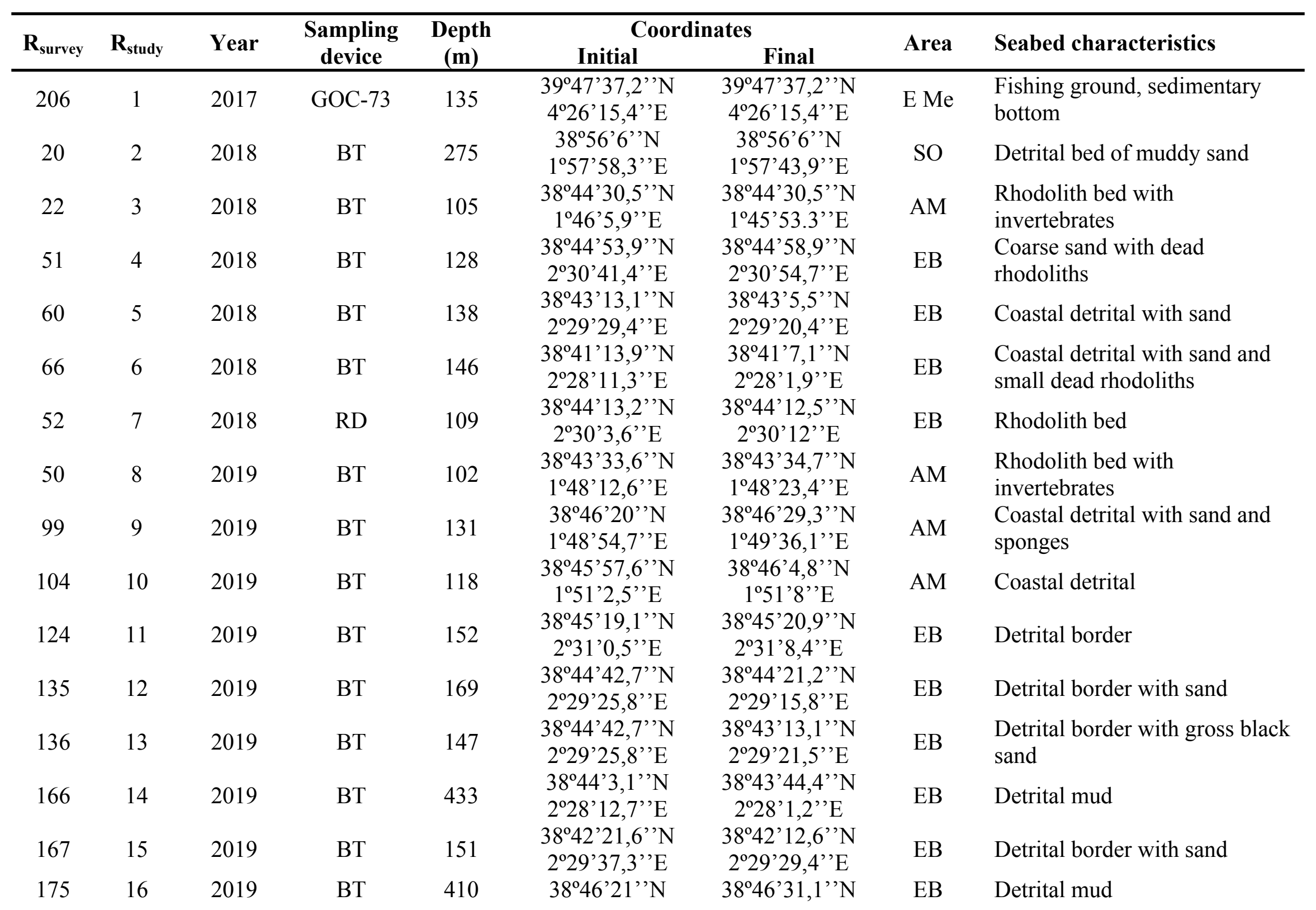




\begin{tabular}{|c|c|c|c|c|c|c|c|c|}
\hline 177 & 17 & 2019 & BT & 156 & $\begin{array}{c}2^{\circ} 30^{\prime} 44,3^{\prime \prime} \mathrm{E} \\
38^{\circ} 43^{\prime} 57,7^{\prime}, \mathrm{N} \\
2^{\circ} 28^{\prime} 54,1^{\prime \prime} \mathrm{E}\end{array}$ & $\begin{array}{l}2^{\circ} 31^{\prime} 5,9^{\prime \prime} \mathrm{E} \\
38^{\circ} 43^{\prime} 47^{\prime \prime} \mathrm{N} \\
2^{\circ} 28^{\prime} 53,4^{\prime \prime} \mathrm{E}\end{array}$ & EB & Detrital border with sand \\
\hline 95 & 18 & 2019 & $\mathrm{RD}$ & $\begin{array}{l}275- \\
220\end{array}$ & $\begin{array}{l}38^{\circ} 47.8^{\prime} 0^{\prime}, \mathrm{N} \\
1^{\circ} 52.6^{\prime} 0^{\prime \prime} \mathrm{E}\end{array}$ & $\begin{array}{l}38^{\circ} 47.7^{\prime} 0{ }^{\prime}, \mathrm{N} \\
1^{\circ} 52.4^{\prime} 0^{\prime}, \mathrm{E}\end{array}$ & $\mathrm{AM}$ & Rocky slope \\
\hline 103 & 19 & 2019 & $\mathrm{RD}$ & $\begin{array}{l}302- \\
231\end{array}$ & $\begin{array}{c}38^{\circ} 47.4^{\prime} 0^{\prime}, \mathrm{N} \\
1^{\circ} 47.2^{\prime} 0^{\prime}, \mathrm{E}\end{array}$ & $\begin{array}{l}38^{\circ} 47.3^{\prime}, 0,{ }^{\prime} \mathrm{N} \\
1^{\circ} 47.2^{\prime} 0^{\prime}, \mathrm{E}\end{array}$ & $\mathrm{AM}$ & Rocky slope \\
\hline 224 & 20 & 2019 & GOC-73 & 252 & $\begin{array}{l}39^{\circ} 3{ }^{\prime} 3,6^{\prime}, \mathrm{N} \\
2^{\circ} 42^{\prime} 2,9^{\prime}, \mathrm{E}\end{array}$ & $\begin{array}{l}39^{\circ} 5^{\prime} 15,7^{\prime}, \mathrm{N} \\
2^{\circ} 42^{\prime} 13,3^{\prime \prime} \mathrm{E}\end{array}$ & SW Ca & $\begin{array}{l}\text { Fishing ground, sedimentary } \\
\text { bottom }\end{array}$ \\
\hline 225 & 21 & 2019 & GOC-73 & 754 & $\begin{array}{l}38^{\circ} 57^{\prime} 11,5^{\prime}{ }^{\prime} \mathrm{N} \\
2^{\circ} 37^{\prime} 54,1^{\prime \prime} \mathrm{E}\end{array}$ & $\begin{array}{l}39^{\circ} 00^{\prime} 2,9^{\prime \prime} \mathrm{N} \\
2^{\circ} 38^{\prime} 33^{\prime \prime} \mathrm{E}\end{array}$ & SW Ca & Fishing ground, bathyal mud \\
\hline 1 & 22 & 2020 & BT & 289 & $\begin{array}{l}38^{\circ} 58^{\prime} 0,5^{\prime}, \mathrm{N} \\
2^{\circ} 0{ }^{\prime} 22,7^{\prime \prime} \mathrm{E}\end{array}$ & $\begin{array}{l}38^{\circ} 58^{\prime} 14,9^{\prime}{ }^{\prime} \mathrm{N} \\
2^{\circ} 0^{\prime} 0^{\prime \prime} \mathrm{E}\end{array}$ & $\mathrm{SO}$ & $\begin{array}{l}\text { Detrital with encrusting } \\
\text { sponges and small crustaceans }\end{array}$ \\
\hline 17 & 23 & 2020 & BT & 113 & $\begin{array}{l}38^{\circ} 45^{\prime} 15,5^{\prime \prime} \mathrm{N} \\
1^{\circ} 46^{\prime} 53,4^{\prime \prime} \mathrm{E}\end{array}$ & $\begin{array}{l}38^{\circ} 45^{\prime} 4,7^{\prime}{ }^{\prime} \mathrm{N} \\
1^{\circ} 46^{\prime} 36,1^{\prime \prime} \mathrm{E}\end{array}$ & $\mathrm{AM}$ & $\begin{array}{l}\text { Rhodolith bed with } \\
\text { invertebrates }\end{array}$ \\
\hline 18 & 24 & 2020 & BT & 114 & $\begin{array}{l}38^{\circ} 45^{\prime} 15,5^{\prime \prime} \mathrm{N} \\
1^{\circ} 46^{\prime} 53,4^{\prime \prime} \mathrm{E}\end{array}$ & $\begin{array}{l}38^{\circ} 45^{\prime} 16,2^{\prime}, \mathrm{N} \\
1^{\circ} 46^{\prime} 54,1^{\prime \prime} \mathrm{E}\end{array}$ & $\mathrm{AM}$ & $\begin{array}{l}\text { Rhodolith bed with } \\
\text { invertebrates }\end{array}$ \\
\hline 45 & 25 & 2020 & BT & 147 & $\begin{array}{l}38^{\circ} 42^{\prime} 51,8^{\prime}, \mathrm{N} \\
2^{\circ} 30^{\prime} 13,7^{\prime}, \mathrm{E}\end{array}$ & $\begin{array}{l}38^{\circ} 42^{\prime} 28,1^{\prime}{ }^{\prime} \mathrm{N} \\
2^{\circ} 29^{\prime} 24^{\prime}, \mathrm{E}\end{array}$ & EB & $\begin{array}{l}\text { Coarse sand and gravel with } \\
\text { crustaceans and sponges }\end{array}$ \\
\hline 52 & 26 & 2020 & BT & 320 & $\begin{array}{c}38^{\circ} 45^{\prime} 47,5^{\prime \prime} \mathrm{N} \\
2^{\circ} 31^{\prime} 0,5^{\prime}{ }^{\prime} \mathrm{E}\end{array}$ & $\begin{array}{l}38^{\circ} 45^{\prime} 56,9^{\prime}, \mathrm{N} \\
2^{\circ} 30^{\prime} 37,1^{\prime \prime} \mathrm{E}\end{array}$ & EB & $\begin{array}{l}\text { Organogenic sediments, shells } \\
\text { rests and gravel with sponges }\end{array}$ \\
\hline 3 & 27 & 2020 & $\mathrm{RD}$ & $\begin{array}{l}288- \\
318\end{array}$ & $\begin{array}{l}38^{\circ} 56^{\prime} 4,7^{\prime}{ }^{\prime} \mathrm{N} \\
1^{\circ} 59^{\prime} 48,1^{\prime}, \mathrm{E}\end{array}$ & $\begin{array}{c}38^{\circ} 56^{\prime} 44,5^{\prime}{ }^{\prime} \mathrm{N} \\
1^{\circ} 59^{\prime} 46,3^{\prime \prime} \mathrm{E}\end{array}$ & $\mathrm{SO}$ & $\begin{array}{l}\text { Rocks and rests of fossil } \\
\text { Ostreids }\end{array}$ \\
\hline 7 & 28 & 2020 & $\mathrm{RD}$ & $\begin{array}{l}325- \\
255\end{array}$ & $\begin{array}{c}38^{\circ} 58^{\prime} 41,99^{\prime \prime} \mathrm{N} \\
1^{\circ} 59^{\prime} 2,4{ }^{\prime \prime} \mathrm{E}\end{array}$ & $\begin{array}{c}38^{\circ} 58^{\prime} 33,6^{\prime} \mathrm{N} \\
1^{\circ} 59^{\prime} 8,5^{\prime \prime} \mathrm{E}\end{array}$ & $\mathrm{SO}$ & $\begin{array}{l}\text { Rocks, rests of fossil Ostreids } \\
\text { and fossil corals }\end{array}$ \\
\hline 8 & 29 & 2020 & $\mathrm{RD}$ & $\begin{array}{l}315- \\
295\end{array}$ & $\begin{array}{c}38^{\circ} 58^{\prime} 11,3, ' \mathrm{~N} \\
2^{\circ} 0{ }^{\prime} 30,6{ }^{\prime \prime} \mathrm{E}\end{array}$ & $\begin{array}{l}38^{\circ} 58^{\prime} 12^{\prime \prime} \mathrm{N} \\
2^{\circ} 0^{\prime} 25,2^{\prime \prime} \mathrm{E}\end{array}$ & $\mathrm{SO}$ & $\begin{array}{l}\text { Rocks and rests of fossil } \\
\text { Ostreids }\end{array}$ \\
\hline 14 & 30 & 2020 & $\mathrm{RD}$ & $\begin{array}{l}325- \\
270\end{array}$ & $\begin{array}{c}38^{\circ} 55^{\prime} 33,6^{\prime \prime} \mathrm{N} \\
1^{\circ} 58^{\prime} 5,6^{\prime \prime} \mathrm{E}\end{array}$ & $\begin{array}{c}38^{\circ} 55^{\prime} 45,1^{\prime}{ }^{\prime} \mathrm{N} \\
1^{\circ} 58^{\prime} 1,2^{\prime \prime} \mathrm{E}\end{array}$ & $\mathrm{SO}$ & Mud, rocks and fossil Ostreids \\
\hline 20 & 31 & 2020 & $\mathrm{RD}$ & $\begin{array}{c}104- \\
138\end{array}$ & $\begin{array}{l}38^{\circ} 42^{\prime} 51,1^{\prime \prime} \mathrm{N} \\
1^{\circ} 466^{\prime} 28,2^{\prime \prime} \mathrm{E}\end{array}$ & $\begin{array}{l}38^{\circ} 43^{\prime} 14,5^{\prime}, \mathrm{N} \\
1^{\circ} 46^{\prime} 27,5^{\prime \prime} \mathrm{E}\end{array}$ & AM & Rhodolith bed with sponges \\
\hline 27 & 32 & 2020 & $\mathrm{RD}$ & $\begin{array}{c}222- \\
195\end{array}$ & $\begin{array}{l}38^{\circ} 47^{\prime} 31,2^{\prime}{ }^{\prime} \mathrm{N} \\
1^{\circ} 52^{\prime} 43,7^{\prime \prime} \mathrm{E}\end{array}$ & $\begin{array}{l}38^{\circ} 47^{\prime} 28,7^{\prime}, \mathrm{N} \\
1^{\circ} 52^{\prime} 31,8^{\prime \prime} \mathrm{E}\end{array}$ & $\mathrm{AM}$ & $\begin{array}{l}\text { Carbonated rocks with } \\
\text { encrusting sponges and gravels }\end{array}$ \\
\hline
\end{tabular}




\begin{tabular}{|c|c|c|c|c|c|c|c|c|}
\hline 28 & 33 & 2020 & $\mathrm{RD}$ & $\begin{array}{l}135- \\
140\end{array}$ & $\begin{array}{c}38^{\circ} 45^{\prime}, 56,5^{\prime}, \mathrm{N} \\
1^{\circ} 51^{\prime} 51,5^{\prime}{ }^{\prime} \mathrm{E}\end{array}$ & $\begin{array}{l}38^{\circ} 466^{\prime} 3,7^{\prime}{ }^{\prime} \mathrm{N} \\
1^{\circ} 51^{\prime} 45,7^{\prime}, \mathrm{E}\end{array}$ & $\mathrm{AM}$ & $\begin{array}{l}\text { Rhodolith bed and rocks with } \\
\text { sponges }\end{array}$ \\
\hline 43 & 34 & 2020 & $\mathrm{RD}$ & $\begin{array}{l}118- \\
116\end{array}$ & $\begin{array}{l}38^{\circ} 44^{\prime} 25,1^{\prime \prime} \mathrm{N} \\
2^{\circ} 30^{\prime} 40,3^{\prime}, \mathrm{E}\end{array}$ & $\begin{array}{c}38^{\circ} 44^{\prime} 26,9^{\prime}, \mathrm{N} \\
2^{\circ} 30^{\prime} 33,5^{\prime}{ }^{\prime} \mathrm{E}\end{array}$ & EB & $\begin{array}{l}\text { Rhodolith bed and rocks with } \\
\text { sponges }\end{array}$ \\
\hline 46 & 35 & 2020 & $\mathrm{RD}$ & $\begin{array}{r}280- \\
306\end{array}$ & $\begin{array}{l}38^{\circ} 42^{\prime} 21,6^{\prime}{ }^{\prime} \mathrm{N} \\
2^{\circ} 30^{\prime} 44,3^{\prime \prime} \mathrm{E}\end{array}$ & $\begin{array}{l}38^{\circ} 42^{\prime} 31,3^{\prime}, \mathrm{N} \\
2^{\circ} 30^{\prime} 42,5^{\prime}, \mathrm{E}\end{array}$ & EB & $\begin{array}{l}\text { Basaltic rocks and fossil } \\
\text { Ostreids with encrusting } \\
\text { sponges }\end{array}$ \\
\hline 94 & 36 & 2020 & GOC-73 & 142 & $\begin{array}{l}39^{\circ} 1113,8^{\prime \prime} \mathrm{N} \\
2^{\circ} 51^{\prime} 2,5^{\prime \prime} \mathrm{E}\end{array}$ & $\begin{array}{l}39^{\circ} 2^{\prime} 16,8^{\prime \prime} \mathrm{N} \\
2^{\circ} 49^{\prime} 43,7^{\prime}{ }^{\prime} \mathrm{E}\end{array}$ & SW Ca & $\begin{array}{l}\text { Fishing ground, sedimentary } \\
\text { bottom }\end{array}$ \\
\hline $07 \_1$ & 37 & 2020 & ROV & $\begin{array}{c}249- \\
122\end{array}$ & $\begin{array}{l}38^{\circ} 45^{\prime}, 44,7, ' \mathrm{~N} \\
1^{\circ} 46^{\prime} 0,8^{\prime \prime} \mathrm{E}\end{array}$ & $\begin{array}{l}38^{\circ} 45^{\prime} 22,3^{\prime}, \mathrm{N} \\
1^{\circ} 46^{\prime} 22,1^{\prime}, \mathrm{E}\end{array}$ & $\mathrm{AM}$ & $\begin{array}{l}\text { Sedimentary slope and } \\
\text { rhodolith bed with sponges }\end{array}$ \\
\hline 13 & 38 & 2020 & ROV & $\begin{array}{l}465- \\
352\end{array}$ & $\begin{array}{l}38^{\circ} 48^{\prime} 22,33^{\prime \prime} \mathrm{N} \\
1^{\circ} 52^{\prime} 57^{\prime \prime} \mathrm{E}\end{array}$ & $\begin{array}{c}38^{\circ} 48^{\prime} 26,3^{\prime \prime} \mathrm{N} \\
1^{\circ} 52^{\prime} 39,4^{\prime \prime} \mathrm{E}\end{array}$ & $\mathrm{AM}$ & Rocky slope with large sponges \\
\hline 23 & 39 & 2020 & ROV & $\begin{array}{l}133- \\
169\end{array}$ & $\begin{array}{l}38^{\circ} 44^{\prime} 27,6^{\prime \prime} \mathrm{N} \\
2^{\circ} 29^{\prime} 15^{\prime \prime} \mathrm{E}\end{array}$ & $\begin{array}{c}38^{\circ} 44,40,2^{\prime}{ }^{\prime} \mathrm{N} \\
2^{\circ} 29^{\prime} 43,4^{\prime}{ }^{\prime} \mathrm{E}\end{array}$ & EB & $\begin{array}{l}\text { Rocky slope, rhodolith bed with } \\
\text { sponges and corals }\end{array}$ \\
\hline 24 & 40 & 2020 & ROV & $\begin{array}{l}150- \\
134\end{array}$ & $\begin{array}{l}38^{\circ} 44^{\prime} 46^{\prime \prime} \mathrm{N} \\
2^{\circ} 29^{\prime} 28,3^{\prime \prime} \mathrm{E}\end{array}$ & $\begin{array}{l}38^{\circ} 44^{\prime} 57,5^{\prime} \mathrm{N} \\
2^{\circ} 29^{\prime} 54,2^{\prime}{ }^{\prime} \mathrm{E}\end{array}$ & EB & $\begin{array}{l}\text { Rocky slope and summit, } \\
\text { rhodolith bed with sponges and } \\
\text { corals }\end{array}$ \\
\hline
\end{tabular}




\section{Table 2 (on next page)}

Comparative characters of Foraminospongia balearica sp. nov. and Foraminospongia minuta sp. nov.

Depth (m), area (SO: Ses Olives; AM: Ausias March; EB: Emile Baudot) and sampling station (St; see Rstudy in Table 1) where these specimens were collected are also shown. Spicule measures are given as minimum- mean -maximum for total length $x$ minimum- mean maximum for total width. A minimum of 30 spicules per spicule kind are measured, otherwise it is stated. All measurements are expressed in $\mu \mathrm{m}$. Specimen codes are the reference numbers of the CFM-IEOMA/and author collection. np: not present. 


\begin{tabular}{|c|c|c|c|c|c|}
\hline Specimen & Style & Rhabdostyle & Oxea & Depth & Area \\
\hline \multicolumn{6}{|c|}{ Foraminospongia balearica $\mathbf{s p . ~ n o v . ~}$} \\
\hline $\begin{array}{l}\text { CFM-IEOMA-7356/i802 } \\
\text { Holotype }\end{array}$ & $\begin{array}{c}188-\underline{378}-492 \times 6-\underline{11-} \\
14\end{array}$ & $90-179 \times 4-7(n=9)$ & $456-609 \times 9-11(n=3)$ & $249-122$ & $\begin{array}{c}\text { AM } \\
\text { St } 13\end{array}$ \\
\hline $\begin{array}{l}\text { CFM-IEOMA-7357/i144 } \\
\text { Paratype }\end{array}$ & $197-\underline{378}-501 \times 4-\underline{9}-12$ & $108-164 \times 3-5(n=5)$ & $\begin{array}{c}249-\underline{493}-656 \times 4-\underline{8}-12(\mathrm{n}= \\
15)\end{array}$ & 128 & $\begin{array}{l}\text { EB } \\
\text { St } 4\end{array}$ \\
\hline $\begin{array}{l}\text { CFM-IEOMA-7358/i293_1 } \\
\text { Paratype }\end{array}$ & $179-\underline{356}-516 \times 3-\underline{8}-14$ & $138-179 \times 3-6(n=5)$ & $328-\underline{527}-763 \times 3-\underline{8}-13$ & 127 & $\begin{array}{l}\text { AM } \\
\text { St } 9\end{array}$ \\
\hline $\begin{array}{l}\text { CFM-IEOMA-7361/i824_4 } \\
\text { Paratype }\end{array}$ & $177-\underline{403}-634 \times 5-\underline{9}-13$ & $92-165 \times 3-6(n=9)$ & $600 \times 9(n=1)$ & $133-169$ & $\begin{array}{r}\text { EB } \\
\text { St } 39 \\
\end{array}$ \\
\hline \multicolumn{6}{|c|}{ Foraminospongia minuta sp. nov. } \\
\hline $\begin{array}{l}\text { CFM-IEOMA-7362/i439 } \\
\text { Holotype }\end{array}$ & $\begin{array}{c}283-\underline{509-658} \times 9 \text { x }-\underline{14-} \\
21\end{array}$ & $175-262 \times 7-9(n=7)$ & $\mathrm{np}$ & $318-288$ & $\begin{array}{l}\text { SO } \\
\text { St } 26\end{array}$ \\
\hline $\begin{array}{l}\text { CFM-IEOMA-7363/i474 } \\
\text { Paratype }\end{array}$ & $\begin{array}{l}244-\underline{416}-555 \times 10-\underline{14}- \\
20\end{array}$ & $147-232 \times 7-9(n=4)$ & $\mathrm{np}$ & $315-295$ & $\begin{array}{r}\text { SO } \\
\text { St } 28 \\
\end{array}$ \\
\hline
\end{tabular}

1 


\section{Table 3 (on next page)}

Comparative characters of the collected specimens of Axinella spatula Sitjà \& Maldonado, 2014, and those reported for the type material (Sitjà \& Maldonado, 2014).

Depth (m), area (EB: Emile Baudot) and sampling station (St; see Rstudy in Table 1) where these specimens were collected are also shown. Spicule measures are given as minimummean -maximum for total length $\mathrm{x}$ minimum-mean-maximum for total width (or as they appear in the cited texts). A minimum of 30 spicules per spicule kind are measured, otherwise it is stated. All measurements are expressed in $\mu \mathrm{m}$. Specimen codes are the reference numbers of the CFM-IEOMA/and author collection for the Balearic specimens and the reference numbers of Invertebrate Collection of the National Museum of Natural Sciences (MNCN) of Madrid for Sitjà \& Maldonado, (2014) specimens. 


\begin{tabular}{|c|c|c|c|c|c|c|}
\hline Specimen & Styles & Oxeas & Trichodragmata & Color & Depth & Area \\
\hline $\begin{array}{l}\text { MNCN-Sp145- } \\
\text { BV33A } \\
\text { Sitjà \& Maldonado, } \\
\text { (2014) } \\
\text { Holotype }\end{array}$ & $165-1050 \times 3-15$ & $180-520 \times 2.5-15$ & $25-30 \times 5-8$ & Beige after EtOH & $134-173$ & $\begin{array}{l}\text { Alboran } \\
\text { Island }\end{array}$ \\
\hline $\begin{array}{l}\text { MNCN-Sp188- } \\
\text { BV41A } \\
\text { Sitjà \& Maldonado, } \\
\text { (2014) } \\
\text { Paratype }\end{array}$ & $119-1400 \times 4-15$ & $190-750 \times 5-20$ & $25-35 \times 5-8$ & Beige after EtOH & $102-112$ & $\begin{array}{l}\text { Alboran } \\
\text { Island }\end{array}$ \\
\hline $\begin{array}{l}\text { MNCN-Sp57-BV21B } \\
\text { Sitjà \& Maldonado, } \\
\text { (2014) } \\
\text { Paratype }\end{array}$ & $245-1225 \times 8-18$ & $120-432 \times 9-12$ & $25-30 \times 6-10$ & Black after EtOH & $93-101$ & $\begin{array}{l}\text { Alboran } \\
\text { Island }\end{array}$ \\
\hline $\begin{array}{l}\text { CFM-IEOMA- } \\
\text { 7364/i338_1A } \\
\text { This work }\end{array}$ & $\begin{array}{l}349-\underline{613}-1161 \times 7- \\
\underline{13}-16(\mathrm{n}=20)\end{array}$ & $\begin{array}{l}187-374-507 \times 5- \\
11-16\end{array}$ & $\begin{array}{l}32-39-47 \times 5-7- \\
10\end{array}$ & $\begin{array}{l}\text { Orange in life } \\
\text { orange beige after } \\
\text { EtOH }\end{array}$ & 152 & $\begin{array}{l}\text { EB } \\
\text { St } 11\end{array}$ \\
\hline $\begin{array}{l}\text { CFM-IEOMA- } \\
\text { 7365/i338_1B } \\
\text { This work }\end{array}$ & $\begin{array}{l}248-900-1304 x \\
11-\underline{17-26}(n=17)\end{array}$ & $\begin{array}{l}219-\underline{377}-485 \times 7- \\
\underline{11}-16\end{array}$ & $\begin{array}{l}36-\underline{45}-56 \times 5-\underline{7}-8 \\
(n=9)\end{array}$ & $\begin{array}{l}\text { Orange in life } \\
\text { orange beige after } \\
\text { EtOH }\end{array}$ & 152 & $\begin{array}{l}\text { EB } \\
\text { St } 11\end{array}$ \\
\hline $\begin{array}{l}\text { CFM-IEOMA- } \\
\text { 7366/i338_1C } \\
\text { This work }\end{array}$ & $\begin{array}{l}332-\underline{638}-1265 \times 4- \\
\underline{12}-17(\mathrm{n}=23)\end{array}$ & $\begin{array}{l}247-332-493 \times 7- \\
\underline{10}-16\end{array}$ & $\begin{array}{l}32-\underline{39-52} \times 5-\underline{7}- \\
11\end{array}$ & $\begin{array}{l}\text { Orange in life } \\
\text { orange beige after } \\
\text { EtOH }\end{array}$ & 152 & $\begin{array}{l}\text { EB } \\
\text { St } 11\end{array}$ \\
\hline
\end{tabular}




\section{Table 4 (on next page)}

Comparative characters of species of the genus Heteroxya.

Depth (m), area (SO: Ses Olives; EB: Emile Baudot) and sampling station (St; see Rstudy in Table 1) where these specimens were collected are also shown. Spicule measures are given as minimum- mean -maximum for total length $\mathrm{x}$ minimum- mean -maximum for total width. $\mathrm{A}$ minimum of 30 spicules per spicule kind are measured, otherwise it is stated. All measurements are expressed in $\mu \mathrm{m}$. Specimen codes are the reference numbers of the CFMIEOMA/author collection. np: not present, nm: not measured. 


\begin{tabular}{|c|c|c|c|c|c|}
\hline Specimen & Oxea I & Oxea II & Style & Depth & Area \\
\hline \multicolumn{6}{|l|}{ Heteroxya corticata } \\
\hline $\begin{array}{l}\text { Topsent, (1898) } \\
\text { Syntypes } \\
\text { redescribed by Morrow et al., } \\
(2019)\end{array}$ & $\begin{array}{l}1600-1700-2000 \times 26- \\
\text { 32-37, Microspined ends }\end{array}$ & $\begin{array}{l}235-310-420 \times 12-23 \\
\text { Pronounced spination } \\
\text { (more at the tips) }\end{array}$ & $\mathrm{np}$ & $1165-1240$ & Azores \\
\hline \multicolumn{6}{|l|}{ Heteroxya beauforti } \\
\hline $\begin{array}{l}\text { Morrow et al., (2019) } \\
\text { Holotype }\end{array}$ & $\begin{array}{l}622-\underline{1030}-1385 \times 10-\underline{16}- \\
21 \\
\text { Smooth }\end{array}$ & $\begin{array}{l}207-280-370 \times 11-\underline{14-16} \\
\text { Smooth }\end{array}$ & $\begin{array}{l}5000-5650- \\
6300 \times 23-25- \\
27\end{array}$ & $629-1469$ & Celtic Seas \\
\hline \multicolumn{6}{|l|}{ Heteroxya cf. beauforti } \\
\hline CFM-IEOMA-7380/i726 & $\begin{array}{l}434-569 \times 7-13(n=7) \\
\text { Smooth }\end{array}$ & $\begin{array}{l}107-180-287 \times 4-6-9 \\
\text { Smooth }\end{array}$ & broken & $280-306$ & $\begin{array}{l}\text { EB } \\
\text { St } 35\end{array}$ \\
\hline CFM-IEOMA-7381/i444 & $\begin{array}{l}319-467-580 \times 6-10-14 \\
(n=23) \\
\text { Smooth }\end{array}$ & $\begin{array}{l}104-\underline{171}-257 \times 4-\underline{6}-8 \\
\text { Smooth }(n=23)\end{array}$ & $\begin{array}{l}1151-3502 / 8- \\
14(\mathrm{n}=3)\end{array}$ & $288-318$ & $\begin{array}{l}\text { SO } \\
\text { St } 27\end{array}$ \\
\hline CFM-IEOMA-7382/i461 & $\begin{array}{l}327-460-586 \times 6-10-15 \\
\text { Smooth }\end{array}$ & $\begin{array}{l}167-233-286 \times 3-7-9 \\
\text { Smooth }\end{array}$ & broken & $255-325$ & $\begin{array}{l}\text { SO } \\
\text { St } 28\end{array}$ \\
\hline CFM-IEOMA-7379/i727 & $\begin{array}{l}420-\underline{530}-623 \times 9-\underline{12}-15 \\
(\mathrm{n}=18) \\
\text { Smooth }\end{array}$ & $\begin{array}{l}142-\underline{192}-293 \times 6-\underline{8}-10 \\
\text { Smooth }\end{array}$ & broken & $280-306$ & $\begin{array}{l}\text { EB } \\
\text { St } 35\end{array}$ \\
\hline CFM-IEOMA-7450 /i487 & $\mathrm{nm}$ & $\mathrm{nm}$ & $\mathrm{nm}$ & $270-325$ & $\begin{array}{l}\text { SO } \\
\text { St } 30\end{array}$ \\
\hline
\end{tabular}




\section{Table 5 (on next page)}

Comparative characters of Paratimea spp. from the Mediterranean and the northeastern Atlantic, including Paratimea massutii sp. nov.

Depth, area (EB: Emile Baudot) and sampling station (St; see Rstudy in Table 1) where these specimens were collected are also shown. Spicule measures are given as minimum- mean maximum for total length $\mathrm{x}$ minimum- mean -maximum for total width. A minimum of 30 spicules per spicule kind are measured, otherwise it is stated. All measurements are expressed in $\mu \mathrm{m}$. Specimen codes are the reference numbers of the CFM-IEOMA/author collection. np: not present, nr: not reported. 


\begin{tabular}{|c|c|c|c|c|c|c|c|}
\hline Species/Specimen & Megascleres & $\begin{array}{l}\text { Accessory } \\
\text { Oxeas }\end{array}$ & Oxyaster & $\begin{array}{l}\text { Other } \\
\text { spicules }\end{array}$ & External morphology & Depth & Area \\
\hline \multicolumn{8}{|c|}{ Paratimea massutii sp. nov.. } \\
\hline $\begin{array}{l}\text { CFM-IEOMA- } \\
\text { 7383/i403 } \\
\text { Holotype }\end{array}$ & $\begin{array}{l}\text { Oxeas } \\
910-1419-1711 \\
x 16-24-33 \\
(n=17)\end{array}$ & $\begin{array}{l}469-\underline{681-}- \\
827 \times 3-\underline{-}- \\
10(n=7)\end{array}$ & $\begin{array}{l}\text { Smooth, } \\
25-36-45 \\
9-25 \text { rays }\end{array}$ & $\mathrm{np}$ & $\begin{array}{l}\text { Massive, lobate surface, } \\
\text { whitish with diatom brownish } \\
\text { on the upper side }\end{array}$ & $151 \mathrm{~m}$ & $\begin{array}{l}\text { EB } \\
\text { St } 15\end{array}$ \\
\hline $\begin{array}{l}\text { CFM-IEOMA- } \\
\text { 7384/i420 } \\
\text { Paratype }\end{array}$ & $\begin{array}{l}\text { Oxeas } \\
1130-\underline{1374-} \\
1561 \times 11-\underline{20}- \\
28\end{array}$ & $\begin{array}{l}556-\underline{755-} \\
862 \times 3-\underline{6}- \\
8\end{array}$ & $\begin{array}{l}\text { Smooth, } \\
27-39-57 \\
7-20 \text { rays } \\
\text { (occasionally } 2 \\
\text { rays) }\end{array}$ & $\mathrm{np}$ & same as $i 403$ & $156 \mathrm{~m}$ & $\begin{array}{l}\text { EB } \\
\text { St } 17\end{array}$ \\
\hline \multicolumn{8}{|c|}{ Paratimea oxeata Pulitzer-Finally, (1978) } \\
\hline Holotype & $\begin{array}{l}1000-1450 x \\
14-24\end{array}$ & $\begin{array}{l}250-650 \times \\
3-7\end{array}$ & $40-60$ & np & $\begin{array}{l}\text { Thickly encrusting, up to } 4 \text { x } 5 \\
\text { x } 0,4 \mathrm{~cm} \text {, drab color in life, } \\
\text { white after formalin and EtOH }\end{array}$ & $\begin{array}{l}60 \\
\text { and } \\
100- \\
110 \mathrm{~m}\end{array}$ & $\begin{array}{l}\text { Bay of } \\
\text { Naples }\end{array}$ \\
\hline $\begin{array}{l}\text { Beertolino et al., } \\
\text { (2013) }\end{array}$ & $\begin{array}{l}810-961-1200 \\
\times 15-\underline{18}-25\end{array}$ & $\begin{array}{l}300-\underline{547-} \\
700 \times 3-\underline{-}- \\
5\end{array}$ & $25-\underline{42}-60$ & np & $\begin{array}{l}\text { Very small }\left(0.5 \mathrm{~cm}^{2}\right) \\
\text { insinuating sponge, grey } \\
\text { colored in dry state. }\end{array}$ & $35 \mathrm{~m}$ & $\begin{array}{l}\text { Liguria } \\
\text { n Sea }\end{array}$ \\
\hline $\begin{array}{l}\text { Morrow et al., } \\
\text { (2019) }\end{array}$ & $\begin{array}{l}1000-1500 x \\
14-24\end{array}$ & $\begin{array}{l}250-650 x \\
3-7\end{array}$ & $\begin{array}{l}20-40 \text { but up to } \\
60 \text { when } \\
\text { reduced rays } \\
4-12 \text { rays }\end{array}$ & $\mathrm{np}$ & $\begin{array}{l}\text { Massive lobose, surface } \\
\text { conulose, oscules arranged on } \\
\text { top of raised humps, Pale } \\
\text { yellow-cream }\end{array}$ & $\begin{array}{l}\text { Caves } \\
, 15- \\
20 \mathrm{~m}\end{array}$ & $\begin{array}{l}\text { Gulf of } \\
\text { Lion }\end{array}$ \\
\hline \multicolumn{8}{|c|}{ Paratimea loricata (Sarà, 1958a) } \\
\hline Holotype & $\begin{array}{l}\text { Oxeas, } \\
\text { poliaxonic and } \\
\text { aberrant } \\
\text { terminations. } \\
\text { Mostly non- } \\
\text { centrotylota. } \\
320-420 \times 5-7\end{array}$ & $\begin{array}{l}\text { Centrotylo } \\
\text { te } \\
105-180 x \\
2-3\end{array}$ & $\begin{array}{l}\text { Large: } 40-50 \\
\text { Small } \\
\text { (uncommon): } \\
12-20\end{array}$ & $\begin{array}{l}\text { Tylostyles, } \\
\text { trilobated } \\
\text { head } \\
130-170 \times 4- \\
7\end{array}$ & $\begin{array}{l}\text { Encrusting, elastic but friable, } \\
\text { whitish-yellow after EtOH }\end{array}$ & $\begin{array}{l}\text { Not } \\
\text { specif } \\
\text { ied, } \\
\text { infrali } \\
\text { ttoral }\end{array}$ & $\begin{array}{l}\text { Liguria } \\
\text { n Sea }\end{array}$ \\
\hline
\end{tabular}




\begin{tabular}{|c|c|c|c|c|c|c|c|}
\hline & $\begin{array}{l}\text { (most } \\
\text { common) } \\
\text { and } 600 \times 15 \\
(\mathrm{n}=1)\end{array}$ & & & & & & \\
\hline \multicolumn{8}{|c|}{ Paratimea pierantonii (Sarà, 1958b) } \\
\hline $\begin{array}{l}\text { Holotype and } \\
\text { paratypes }\end{array}$ & $\begin{array}{l}\text { Styles and } \\
\text { Subtylostyles: } \\
1530-2550 / 12- \\
18\end{array}$ & $\begin{array}{l}\text { 650-1175 } \\
\text { x 4-10, } \\
\text { centrocurv } \\
\text { ed, non- } \\
\text { centrotylot } \\
\text { e }\end{array}$ & $15-25$ & np & $\begin{array}{l}\text { Cushion shaped with papillae. } \\
\text { Hispid, smooth to the touch. } \\
\text { Orange yellow at the surface, } \\
\text { brownish inside. }\end{array}$ & $\begin{array}{l}30 \\
\mathrm{~cm}, \\
\text { tidal } \\
\text { cave }\end{array}$ & $\begin{array}{l}\text { Tyrrhen } \\
\text { ian Sea }\end{array}$ \\
\hline \multicolumn{8}{|c|}{ Paratimea arbuscula (Topsent, 1928) } \\
\hline Holotype & $\begin{array}{l}\text { Curved or } \\
\text { flexuous, } \\
\text { centrotylote. } \\
\text { Some modified } \\
\text { to styles. } 560- \\
1000 \times 5-12\end{array}$ & $\mathrm{nr}$ & $\begin{array}{l}\text { Without } \\
\text { centrum, with } \\
\text { conical, } \\
\text { acanthose } \\
\text { actines, } \\
15-60 \\
\text { most with } 12 \\
\text { rays }\end{array}$ & $\mathrm{np}$ & $\begin{array}{l}\text { Small arbuscular sponge, up to } \\
1 \mathrm{~cm} \text { in heigth } 1 \mathrm{~mm} \text { in width, } \\
\text { hispid. Whitish. Asters } \\
\text { concentrated at the periphery }\end{array}$ & $\begin{array}{l}650- \\
914 \mathrm{~m}\end{array}$ & Azores \\
\hline \multicolumn{8}{|c|}{ Paratimea duplex (Topsent, 1927) } \\
\hline $\begin{array}{l}\text {..Reproduced from } \\
\text { the redescription in } \\
\text { Morrow et al., } \\
\text { (2019) }\end{array}$ & $\begin{array}{l}\text { Centrotylote } \\
\text { oxeas } 2000- \\
2600 \times 20-40 \text {, } \\
\text { styles to } \\
\text { subtylostyles } \\
1600-1800 \times \\
25-35\end{array}$ & $\begin{array}{l}\text { Weakly } \\
\text { centrotylot } \\
\text { e } \\
360-770 x \\
7-9\end{array}$ & $\begin{array}{l}\text { Without } \\
\text { centrum, smooth } \\
\text { rayed, } \\
50-100 \\
10-15 \text { rays }\end{array}$ & np & $\begin{array}{l}\text { cushion shaped, } 3 \mathrm{~mm} \\
\text { thick, with a conulose surface }\end{array}$ & $\begin{array}{l}240- \\
2165 \\
\mathrm{~m}\end{array}$ & $\begin{array}{l}\text { North } \\
\text { Atlantic } \\
\text { Ocean }\end{array}$ \\
\hline \multicolumn{8}{|c|}{ Paratimea constellata (Topsent, 1904) } \\
\hline $\begin{array}{l}\text { Holotype, } \\
\text { reproduced from }\end{array}$ & $\begin{array}{l}\text { Long, slender } \\
\text { tylostyles }\end{array}$ & $\begin{array}{l}\text { Centrotylo } \\
\text { te oxeas }\end{array}$ & $\begin{array}{l}\text { Smooth-rayed } \\
\text { euasters 14-30- }\end{array}$ & $\mathrm{np}$ & $\begin{array}{l}\text { Cushion shaped, } 2-3 \mathrm{~mm} \text { thick, } \\
\text { yellow gold }\end{array}$ & $40 \mathrm{~m}$ & $\begin{array}{l}\text { Roscoff } \\
\text {, Celtic }\end{array}$ \\
\hline
\end{tabular}




\begin{tabular}{|c|c|c|c|c|c|c|c|}
\hline $\begin{array}{l}\text { Morrow et al., } \\
\text { (2019) }\end{array}$ & $\begin{array}{l}2500-3000 \times \\
13-14\end{array}$ & $\begin{array}{l}379-\frac{670-}{8-10} \\
900 \times 8-10\end{array}$ & \multicolumn{4}{|l|}{46} & seas \\
\hline \multicolumn{8}{|c|}{ Paratimea loenbergi (Alander, 1942) } \\
\hline $\begin{array}{l}\text { Reproduced from } \\
\text { the redescription of } \\
\text { the Holotype in } \\
\text { Morrow et al., } \\
\text { (2019) }\end{array}$ & $\begin{array}{l}1350-3000 \times \\
10-13-15 \\
(\mathrm{n}=4) ; \text { head, } \\
16-20-27\end{array}$ & $\begin{array}{l}\text { Slightly } \\
\text { bent, } 530- \\
712-930 x \\
5-\underline{5}-6 \\
(n=7)\end{array}$ & $\begin{array}{l}\text { Smooth 22-28- } \\
36\end{array}$ & $\begin{array}{l}\text { Small } \\
\text { category of } \\
\text { tylostyles not } \\
\text { found by } \\
\text { Morrow et al. } \\
\text { (2019) but } \\
\text { mentioned in } \\
\text { the original } \\
\text { description, } \\
\text { measuring } \\
180-225 \mathrm{x} \\
12-15\end{array}$ & $\begin{array}{l}\text { Thin, hispid } \\
\text { crust, pale yellow. }\end{array}$ & $60 \mathrm{~m}$ & $\begin{array}{l}\text { Väderö } \\
\text { fjord, } \\
\text { Sweden }\end{array}$ \\
\hline
\end{tabular}

Paratimea hoffmannae Morrow \& Cárdenas, 2019

\begin{tabular}{|c|c|c|c|c|c|c|}
\hline $\begin{array}{l}\text { Holotype, original } \\
\text { description }\end{array}$ & $\begin{array}{l}\text { Large, curved } \\
\text { oxeas, } \\
\text { occasionally } \\
\text { centrotylote } \\
2056-2187- \\
2250 \times 25-26- \\
28\end{array}$ & $\begin{array}{l}\text { Rare, bent, } \\
\text { occasional } \\
\text { ly } \\
\text { centrotyle } \\
353-\underline{446}- \\
520 \times 3-\underline{4}- \\
5\end{array}$ & $\begin{array}{l}\text { Asymmetic } 42-\quad n p \\
\frac{60-81 \mu \mathrm{m}}{7-18} \\
\text { smooth, tapering } \\
\text { rays }\end{array}$ & $\begin{array}{l}\text { Massive, subspherical. } \\
\text { Holotype is } \sim 7 \text { in diameter. } \\
\text { Surface covered in large } \\
\text { conules, } \\
1-4 \mathrm{~mm} \text { in height. Creamish } \\
\text { white. }\end{array}$ & $\begin{array}{l}328 \mathrm{~m} \\
(\text { Holot } \\
\text { ype) } \\
1500 \\
\mathrm{~m} \\
\text { (Parat } \\
\text { ype) }\end{array}$ & $\begin{array}{l}\text { Norway } \\
\text { (Holoty } \\
\text { pe) } \\
\text { Ireland } \\
\text { (Paraty } \\
\text { pe) }\end{array}$ \\
\hline
\end{tabular}




\section{Table 6(on next page)}

Comparative characters of representative reports of Dragmatella aberrans.

Depth (m), area (SO: Ses Olives; EB: Emile Baudot) and sampling station (St; see Rstudy in Table 1) where these specimens were collected are also shown. Spicule measures are given as minimum- mean -maximum for total length $\mathrm{x}$ minimum- mean -maximum for total width. $\mathrm{A}$ minimum of 30 spicules per spicule kind are measured, otherwise it is stated. All measurements are expressed in $\mu \mathrm{m}$. Specimen codes are the reference numbers of the CFMIEOMA/author collection. 


\begin{tabular}{|c|c|c|c|c|}
\hline Specimen & Styles & Raphides & Depth & Area \\
\hline Topsent, (1892) & 600 & 180 & $135-134$ & Cantabric Sea \\
\hline Topsent, (1928) & $600-800 \times 9-11.5$ & $70-200 \times 12-20$ & $552-1262$ & Cap Sines (Portugal) \\
\hline Vacelet, (1969) & $350-600 \times 6-13$ & $150-210$ & $250-324$ & $\begin{array}{l}\text { Cassidaigne (Gulf of } \\
\text { Lion) }\end{array}$ \\
\hline Pulitzer-Finali, (1983) & $400-600 \times 6-14$ & 200 & $128-150$ & off Calvi (Corsica) \\
\hline $\begin{array}{l}\text { Boury-esnault et al, } \\
\text { (1994) }\end{array}$ & $\begin{array}{l}315-\underline{571-631 \times 5-11-} \\
16\end{array}$ & 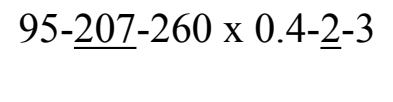 & $\begin{array}{l}485 \text { (Atlantic) } \\
195 \text { (Mediterranean) }\end{array}$ & $\begin{array}{l}\text { Atlantic and Alboran } \\
\text { Sea }\end{array}$ \\
\hline $\begin{array}{l}\text { CFM-IEOMA- } \\
\text { 7387/i52_b1 } \\
\text { This work }\end{array}$ & $349-\underline{555}-676 \times 6-\underline{9}-13$ & $162-\underline{197-222} \times 1-\underline{2}-3$ & 275 & $\begin{array}{l}\mathrm{SO} \\
\mathrm{St} 2\end{array}$ \\
\hline $\begin{array}{l}\text { CFM-IEOMA-7388/i175 } \\
\text { This work }\end{array}$ & $\begin{array}{l}351-\underline{539}-651 \times 8-\underline{11}- \\
15\end{array}$ & $163-\underline{193}-214 \times 1-\underline{-2}-3$ & 138 & $\begin{array}{l}\text { EB } \\
\text { St } 5\end{array}$ \\
\hline
\end{tabular}




\section{Table 7 (on next page)}

Comparative characters from published records of Petrosia (Petrosia) raphida BouryEsnault, Pansini \& Uriz, 1994 and present work.

Depth (m), area (SO: Ses Olives; AM: Ausias March; EB: Emile Baudot) and sampling station (St; see Rstudy in Table 1) where these specimens were collected are also shown. Spicule measures are given as minimum- mean -maximum for total length $\mathrm{x}$ minimum- mean maximum for total width. A minimum of 30 spicules per spicule kind are measured, otherwise it is stated. All measurements are expressed in $\mu \mathrm{m}$. Specimen codes are the reference numbers of the CFM-IEOMA/author collection. 


\begin{tabular}{|c|c|c|c|c|}
\hline Specimen & Oxeas & Raphides & Depth & Area \\
\hline $\begin{array}{l}\text { Boury-Esnault, Pansini \& Uriz, } \\
\text { (1994) } \\
\text { Holotype }\end{array}$ & $\begin{array}{l}354-\underline{449-} \\
499 \times 26-32-36 \text { (strongyles) }\end{array}$ & $81-\underline{95-108 \times 1}$ & 580 & Gibraltar \\
\hline Sitjà et al., (2019) & $\begin{array}{l}290-500 \times 20-25 \text { (rarely as } \\
\text { short as } 7.5 \text { ) }\end{array}$ & $\begin{array}{l}75-100 \times 1 \text { (some without } \\
\text { spines) }\end{array}$ & $530-573$ & $\begin{array}{l}\text { Volcano of Gulf of } \\
\text { Cadiz (Pipoca) }\end{array}$ \\
\hline $\begin{array}{l}\text { CFM-IEOMA-7396/POR406 } \\
\text { This work }\end{array}$ & $271-\underline{369}-432 \times 9-13-16$ & $62-\underline{78}-91 \times 1-1-2$ & 134 & $\begin{array}{l}\text { South-east of } \\
\text { Menorca } \\
\text { St } 1\end{array}$ \\
\hline $\begin{array}{l}\text { CFM-IEOMA-7397/i178_3 } \\
\text { This work }\end{array}$ & $242-\underline{378}-450 \times 10-\underline{16}-19$ & $72-\underline{80}-89$ x 2-י-4 & 138 & $\begin{array}{l}\text { EB } \\
\text { St } 5\end{array}$ \\
\hline $\begin{array}{l}\text { CFM-IEOMA-7451/i242 } \\
\text { This work }\end{array}$ & $268-\underline{333}-380 \times 11-\underline{14}-17$ & $70-\underline{80}-91 \times 1-\underline{-2}-2$ & 101 & $\begin{array}{l}\text { AM } \\
\text { St } 8\end{array}$ \\
\hline $\begin{array}{l}\text { CFM-IEOMA-7398/i254_2 } \\
\text { This work }\end{array}$ & $300-\underline{378}-426 \times 9-\underline{15}-19$ & $66-\underline{75-86} \times 1-\underline{2}-2$ & 101 & $\begin{array}{l}\text { AM } \\
\text { St } 8\end{array}$ \\
\hline $\begin{array}{l}\text { CFM-IEOMA-7399/i305 } \\
\text { This work }\end{array}$ & $242-\underline{346}-394 \times 9-\underline{15}-19$ & $65-\underline{75-88} \times 1-\underline{2}-2$ & 118 & $\begin{array}{l}\text { AM } \\
\text { St } 10\end{array}$ \\
\hline $\begin{array}{l}\text { CFM-IEOMA-7400/i312_1 } \\
\text { This work }\end{array}$ & $349-\underline{403}-453 \times 8-\underline{15}-19$ & $70-\underline{-79}-95 \times 1-\underline{2}-2$ & 152 & $\begin{array}{l}\text { EB } \\
\text { St } 11\end{array}$ \\
\hline
\end{tabular}




\section{Table 8(on next page)}

Comparative characters from Calyx cf. tufa and Calyx tufa Ridley \& Dendy, 1886.

Depth (m), area (AM: Ausias March) and sampling station (St; see Rstudy in Table 1) where these specimens were collected are also shown. Spicule measures are given as minimummean -maximum for total length $x$ minimum- mean -maximum for total width. A minimum of 30 spicules per spicule kind are measured, otherwise it is stated. All measurements are expressed in $\mu \mathrm{m}$. Specimen codes are the reference numbers of the CFM-IEOMA/and author collection. nr: not reported. 


\begin{tabular}{|c|c|c|c|c|}
\hline Specimen & Oxeas & External morphology & Depth & Area \\
\hline \multicolumn{5}{|l|}{ Calyx cf. tufa } \\
\hline $\begin{array}{l}\text { CFM-IEOMA-7403/i525 } \\
\text { This work }\end{array}$ & $146-\underline{170}-189 \times 6-\underline{7}-8$ & $\begin{array}{l}\text { Large, massive, roundish. Surface } \\
\text { smooth. Stony hard and } \\
\text { uncompressible. Ectosomal crust } \\
\text { present. Beige with pink tints at the } \\
\text { upper side. Whitish beige after EtOH }\end{array}$ & 114 & $\begin{array}{l}\text { AM } \\
\text { St } 24\end{array}$ \\
\hline $\begin{array}{l}\text { CFM-IEOMA-7402/i515 } \\
\text { This work }\end{array}$ & $140-\underline{171}-205 \times 4-\underline{7-9}$ & As the Holotype & 113 & $\begin{array}{l}\text { AM } \\
\text { St } 23\end{array}$ \\
\hline $\begin{array}{l}\text { CFM-IEOMA-7401/i75 } \\
\text { This work }\end{array}$ & $132-\underline{178}-206$ x 4- $\underline{6}-9$ & As the Holotype & 105 & $\begin{array}{l}\text { AM } \\
\text { St } 3\end{array}$ \\
\hline \multicolumn{5}{|l|}{ Calyx tufa } \\
\hline $\begin{array}{l}\text { Ridley \& Dendy, (1886) } \\
\text { Holotype }\end{array}$ & $200 \times 10$ & $\begin{array}{l}\text { Massive, cake-like. Firm, almost stony, } \\
\text { but brittle. Surface smooth but uneven. } \\
\text { Dermal membrane (=ectosomal crust) } \\
\text { readily peeling off. Vents rather small, } \\
\text { circular, flush. Greyish yellow. }\end{array}$ & 219 & $\begin{array}{l}\text { St Lago, } \\
\text { Cape } \\
\text { Verde }\end{array}$ \\
\hline Topsent, (1892) & $\mathrm{nr}$ & $\begin{array}{l}\text { Firm but crumbly. Without ectosomal } \\
\text { crust due to damaging. Light brown. }\end{array}$ & 300 & $\begin{array}{l}\text { Cantabrian } \\
\text { Sea }\end{array}$ \\
\hline
\end{tabular}




\section{Table 9 (on next page)}

Comparative characters from Polymastia polytylota Vacelet, 1969.

Depth (m), area (AM: Ausias March) and sampling station (St; see Rstudy in Table 1) where these specimens were collected are also shown. Spicule measures are given as minimummean -maximum for total length $x$ minimum- mean -maximum for total width. A minimum of 30 spicules per spicule kind are measured, otherwise it is stated. All measurements are expressed in $\mu \mathrm{m}$. Specimen codes are the reference numbers of the CFM-IEOMA/and author collection. 


\begin{tabular}{|c|c|c|c|c|c|}
\hline Specimen & $\begin{array}{l}\text { Principal } \\
\text { tylostyles }\end{array}$ & $\begin{array}{l}\text { Intermedium } \\
\text { tylostyles }\end{array}$ & $\begin{array}{l}\text { Ectosomal } \\
\text { tylostyles }\end{array}$ & Depth & Area \\
\hline $\begin{array}{l}\text { Boury-Esnault, (1987) } \\
\text { Redescription of the } \\
\text { Holotype }\end{array}$ & $\begin{array}{l}650-990 \times 10- \\
13\end{array}$ & $210-490 \times 7-10$ & $70-180 \times 2-5$ & $165-270$ & $\begin{array}{l}\text { Toulon, but also in } \\
\text { Corsica }\end{array}$ \\
\hline $\begin{array}{l}\text { Boury-Esnault, Pansini \& } \\
\text { Uriz, (1994) }\end{array}$ & $\begin{array}{l}668-854-1108 x \\
5-13-16\end{array}$ & $\begin{array}{l}276-403-509 \times 5- \\
11-13\end{array}$ & $\begin{array}{l}94-\underline{115}-143 \times 3-\underline{3}- \\
4\end{array}$ & $\begin{array}{l}\text { Alboran: } 480 \\
\text { Atl: } 362- \\
485\end{array}$ & $\begin{array}{l}\text { Alboran Sea and North } \\
\text { Atlantic }\end{array}$ \\
\hline Pulitzer-Finali, (1983) & $\begin{array}{l}650-810 \times 10- \\
13\end{array}$ & $210-490 \times 7-10$ & $80-120 \times 2-3$ & 117 & North of Corsica \\
\hline $\begin{array}{l}\text { CFM-IEOMA-7405/i810 } \\
\text { This work }\end{array}$ & $\begin{array}{l}438-\underline{909}-1154 \times \\
8-\underline{11-15}\end{array}$ & $\begin{array}{l}308-\underline{443}-586 \times 6-\underline{7}- \\
9\end{array}$ & $\begin{array}{l}121-\underline{166}-200 \times 2- \\
\underline{3}-5\end{array}$ & $352-465$ & $\begin{array}{l}\text { AM } \\
\text { St } 3\end{array}$ \\
\hline
\end{tabular}




\section{Table $\mathbf{1 0}$ (on next page)}

Comparative characters from Pseudotrachya hystrix (Topsent, 1890).

Depth (m), area (AM: Ausias March) and sampling station (St; see Rstudy in Table 1) where these specimens were collected are also shown. Spicule measures are given as minimummean -maximum for total length $x$ minimum- mean -maximum for total width. A minimum of 30 spicules per spicule kind are measured, otherwise it is stated. All measurements are expressed in $\mu \mathrm{m}$. Specimen codes are the reference numbers of the CFM-IEOMA/and author collection. nr: not reported. 


\begin{tabular}{|c|c|c|c|c|}
\hline Specimen & Anisoxeas & Microxeas & Depth (m) & Area \\
\hline $\begin{array}{l}\text { Topsent, (1892) } \\
\text { Holotype }\end{array}$ & up to $7000 \times 70$ & $185 \times 6$ & 318 and 454 & Azores \\
\hline Topsent, (1928) & $\mathrm{nr}$ & $\mathrm{nr}$ & $650-914$ & Azores \\
\hline Sarà, (1959) & $4000-5000 \times 35-45$ & $150-240 \times 3-5$ & 100 & Tyrrenhian sea \\
\hline $\begin{array}{l}\text { Boury-Esnault, Pansini \& } \\
\text { Uriz, (1994) }\end{array}$ & $2000-3400-4300 \times 18-44-63$ & $200-235-330 \times 5-6-7$ & $153-568$ & Alboran Sea, \\
\hline $\begin{array}{l}\text { Vacelet, (1969) } \\
\text { (Various specimens) }\end{array}$ & $\begin{array}{l}\text { St15: } 1000-1250 \times 22-30 \\
\text { St23:>2000 × } 30-35 \\
\text { St34: } 1600-6600 \times 18-40 \\
\text { St46:1100-4500 × } 20-60\end{array}$ & $\begin{array}{l}110-320 \times 3-5 \\
\text { Stylote modifications }\end{array}$ & $\begin{array}{l}\text { St 15: } 180 \\
\text { St 23: } 210-240 \\
\text { St 34: } 270 \\
\text { St 46: } 450-550\end{array}$ & $\begin{array}{l}\text { St 15: Cassidaigne } \\
\text { St 23: Corse } \\
\text { St 34: Cassidaigne } \\
\text { St 46: Cassidaigne }\end{array}$ \\
\hline $\begin{array}{l}\text { CFM-IEOMA- } \\
\text { 7406/i303_A } \\
\text { This work }\end{array}$ & $834-\underline{1689}-3358 \times 10-\underline{25}-42$ & $156-\underline{185}-217 \times 4-\underline{5}-6$ & $231-302$ & $\begin{array}{l}\text { AM } \\
\text { St } 19\end{array}$ \\
\hline $\begin{array}{l}\text { CFM-IEOMA-7407/i613 } \\
\text { This work }\end{array}$ & $768-\underline{2088}-3402 \times 18-\underline{32}-45$ & $152-\underline{203}-270 \times 3-\underline{5}-6$ & $195-222$ & $\begin{array}{l}\text { AM } \\
\text { St } 32\end{array}$ \\
\hline
\end{tabular}




\section{Table $\mathbf{1 1}$ (on next page)}

Comparative characters from Lanuginella pupa Schmidt, 1870.

Depth (m), area (AM: Ausias March) and sampling station (St; see Rstudy in Table 1) where these specimens were collected are also shown. Spicule measures are given as minimummean -maximum for total length $x$ minimum- mean -maximum for total width. A minimum of 30 spicules per spicule kind are measured, otherwise it is stated. All measurements are expressed in $\mu \mathrm{m}$. Specimen codes are the reference numbers of the CFM-IEOMA/and author collection. nr: not reported, nf: not found. 


\begin{tabular}{|c|c|c|c|c|c|c|c|c|c|}
\hline & Parenchimalia & & Dermalia & & Gastralia & Hexasters & & & \\
\hline Specimen & $\begin{array}{l}\text { Choanosomal } \\
\text { Diactine }\end{array}$ & $\begin{array}{l}\text { Choanosomal } \\
\text { Hexactine }\end{array}$ & $\begin{array}{l}\text { Hypoderm } \\
\text { al } \\
\text { Pentactine }\end{array}$ & Other & $\begin{array}{l}\text { Atrial } \\
\text { hexactine }\end{array}$ & Discohexaster & $\begin{array}{l}\text { Strombiplu } \\
\text { micomes }\end{array}$ & Depth & Area \\
\hline $\begin{array}{l}\text { Schmidt, } \\
\text { (1870) }\end{array}$ & & & & $\overline{\mathrm{nr}}$ & & & & & $\begin{array}{l}\text { Cape Verde } \\
\text { (Atlantic }\end{array}$ \\
\hline $\begin{array}{l}\text { Holotype } \\
\text { Schulze, } \\
\text { (1897) }\end{array}$ & $\mathrm{nr}$ & $\mathrm{nr}$ & $\mathrm{nr}$ & $\begin{array}{l}\text { Staura } \\
\text { ctines: } \\
160- \\
200\end{array}$ & $\mathrm{nr}$ & $32-\underline{80}-100$ & 40 & 201 & $\begin{array}{l}\text { Ocean) } \\
\text { Little Ki } \\
\text { Island (Banda } \\
\text { Sea) }\end{array}$ \\
\hline $\begin{array}{l}\text { Ijima, } \\
(1904) \\
\text { Several } \\
\text { specimens }\end{array}$ & up to $4000 \times 22$ & $\begin{array}{l}\text { variable in } \\
\text { size, up to } \\
2000 \times 30 \\
\text { (as } \\
\text { oxyhexactine) }\end{array}$ & $1000 \times 34$ & $\begin{array}{l}\text { Staura } \\
\text { ctines } \\
\text { rarely } \\
\text { tauacti } \\
\text { nes, } \\
220- \\
330 \\
\text { (avera } \\
\text { ge } \\
\text { length) } \\
\text { x } 7\end{array}$ & $\begin{array}{l}220-330 x \\
7\end{array}$ & $40-90$ & $34-76$ & $\begin{array}{l}183- \\
572\end{array}$ & $\begin{array}{l}\text { Döketsba, } \\
\text { Okinose, } \\
\text { Mochiyama } \\
\text { (Japan), } \\
\text { Vries Island } \\
\text { (Vries Strait, } \\
\text { Pacific } \\
\text { Ocean) }\end{array}$ \\
\hline $\begin{array}{l}\text { Okada, } \\
1932\end{array}$ & $\begin{array}{l}3500-5000 \times \\
100\end{array}$ & $3000 \times 60$ & $\mathrm{nr}$ & $\mathrm{nr}$ & $\mathrm{nr}$ & $45-80$ & 50 & 180 & $\begin{array}{l}\text { Kagoshima } \\
\text { Gulf (Eastern } \\
\text { China Sea) }\end{array}$ \\
\hline $\begin{array}{l}\text { Burton, } \\
1956\end{array}$ & & & & & $\mathrm{nr}$ & & & & \\
\hline $\begin{array}{l}\text { Sitjà \& } \\
\text { Maldonad } \\
o,(2014)\end{array}$ & $325-3000 \times 4-7$ & $\begin{array}{l}250-850 \times 6- \\
13\end{array}$ & $\begin{array}{l}\text { Perp: } 170- \\
850 \text { x 4-10 } \\
\text { Prox: } \\
242-950 \mathrm{x} \\
8-12\end{array}$ & $\begin{array}{l}\text { Abund } \\
\text { ant } \\
\text { staurac } \\
\text { tines, } \\
\text { scarce } \\
\text { pentac }\end{array}$ & $\begin{array}{l}46-150 \times \\
2-6\end{array}$ & $30-70$ & $\mathrm{nf}$ & 690 & $\begin{array}{l}\text { Gulf of Cadiz } \\
\text { (Mud } \\
\text { volcano, } \\
\text { North } \\
\text { Atlantic } \\
\text { Ocean) }\end{array}$ \\
\hline
\end{tabular}




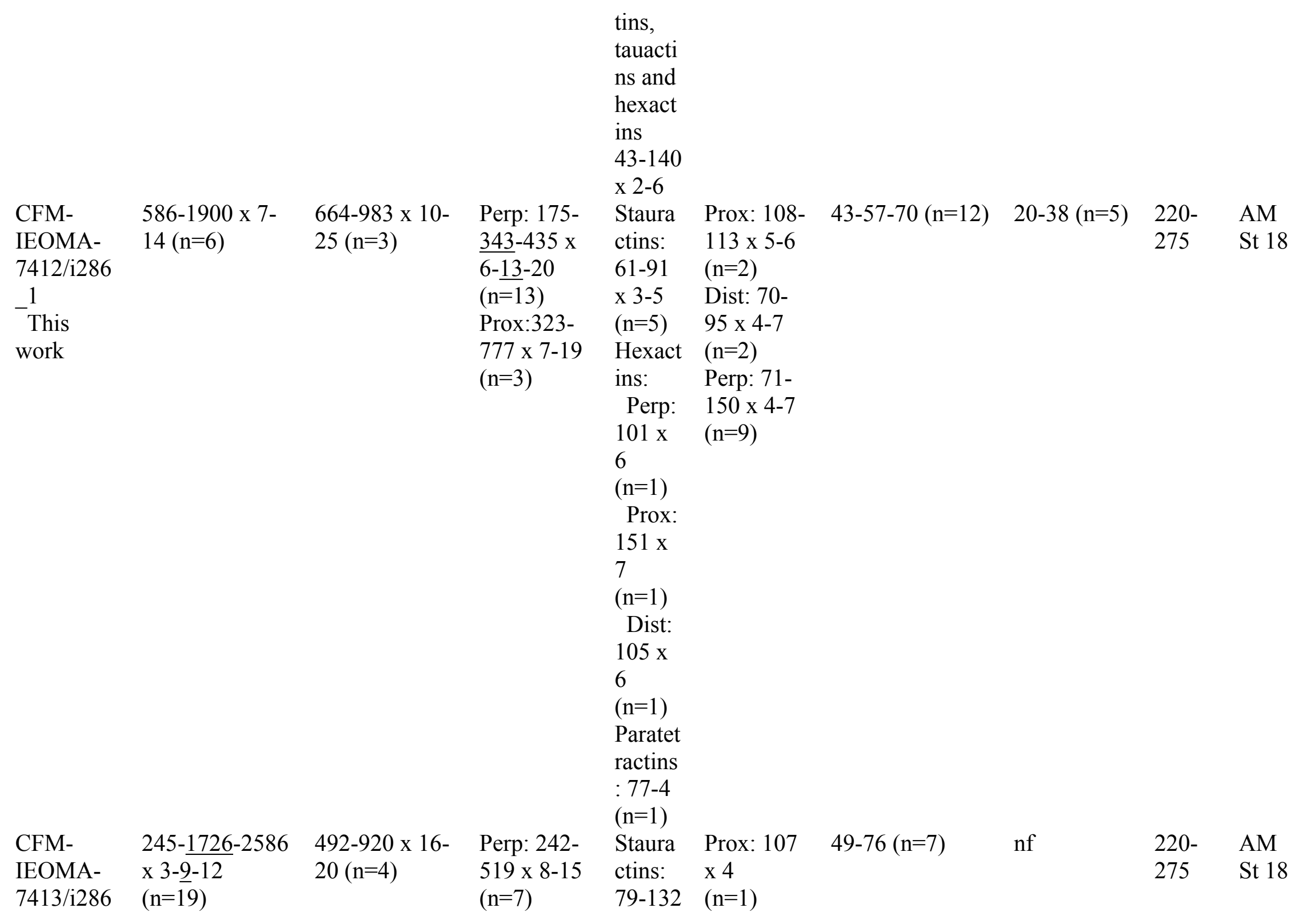




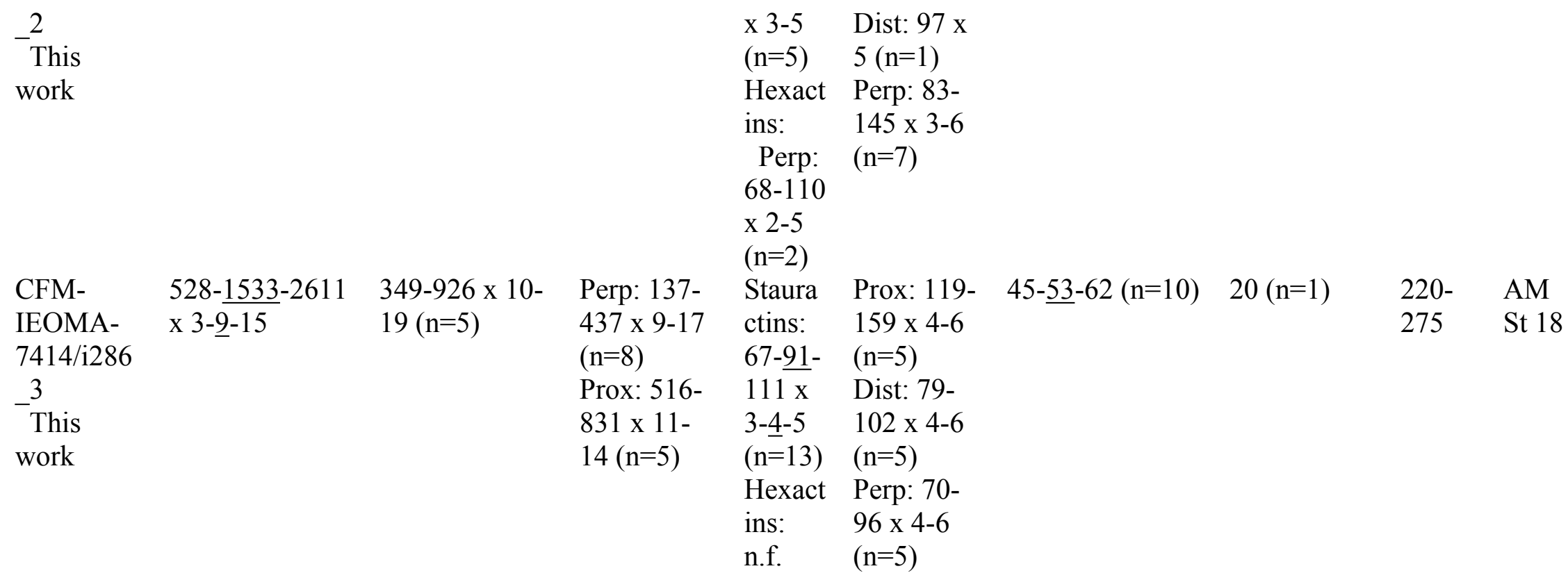

